Historic, Archive Document

Do not assume content reflects current scientific knowledge, policies, or practices. 



\section{BALTIMORE NURSEPTES}

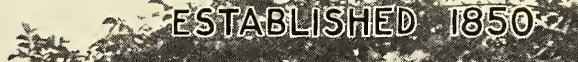

and ond

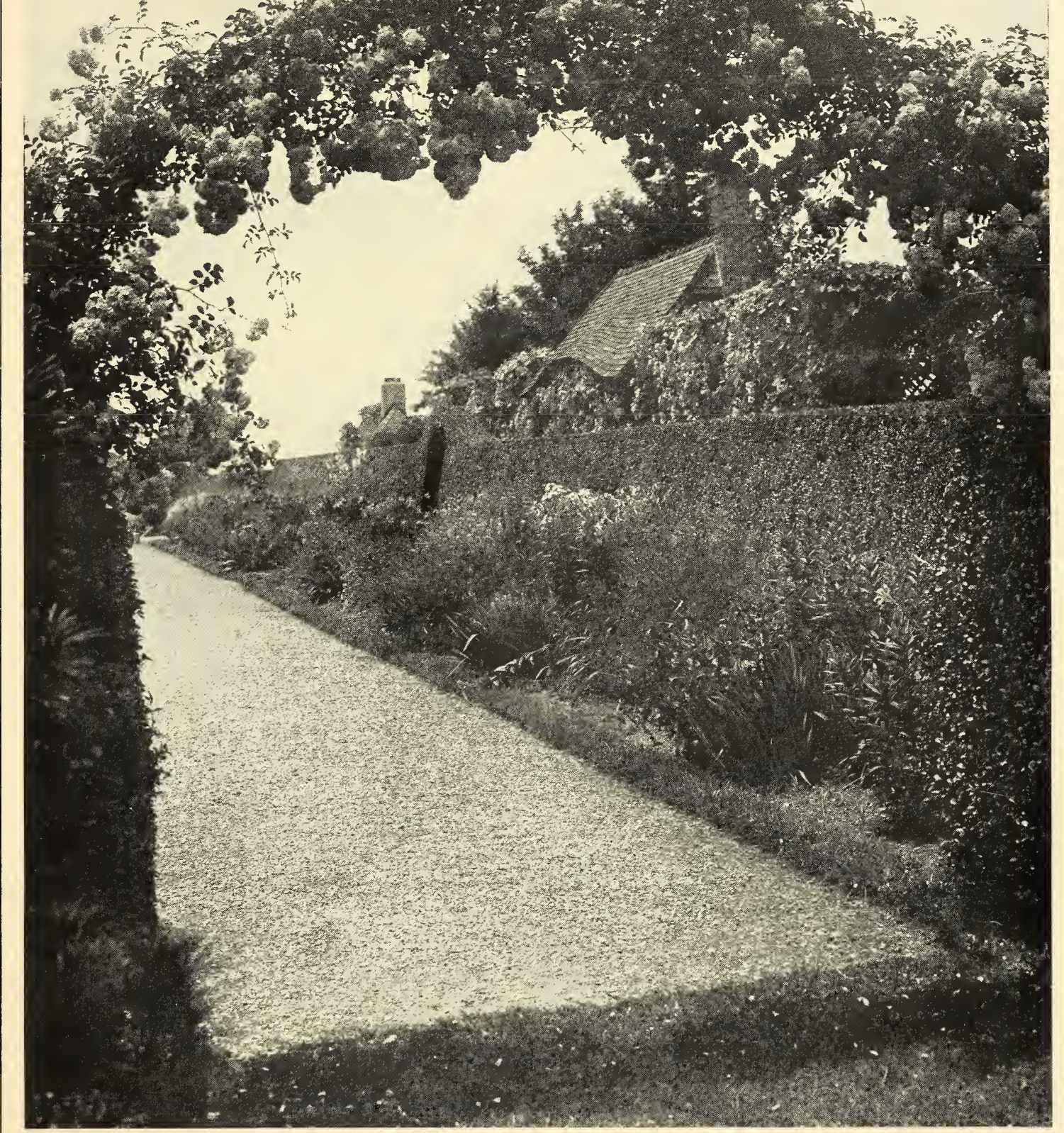

\section{FRANKLIN DAVIS NURSERIES, Inc. Baltimore, Maryland}




\section{N D E X}

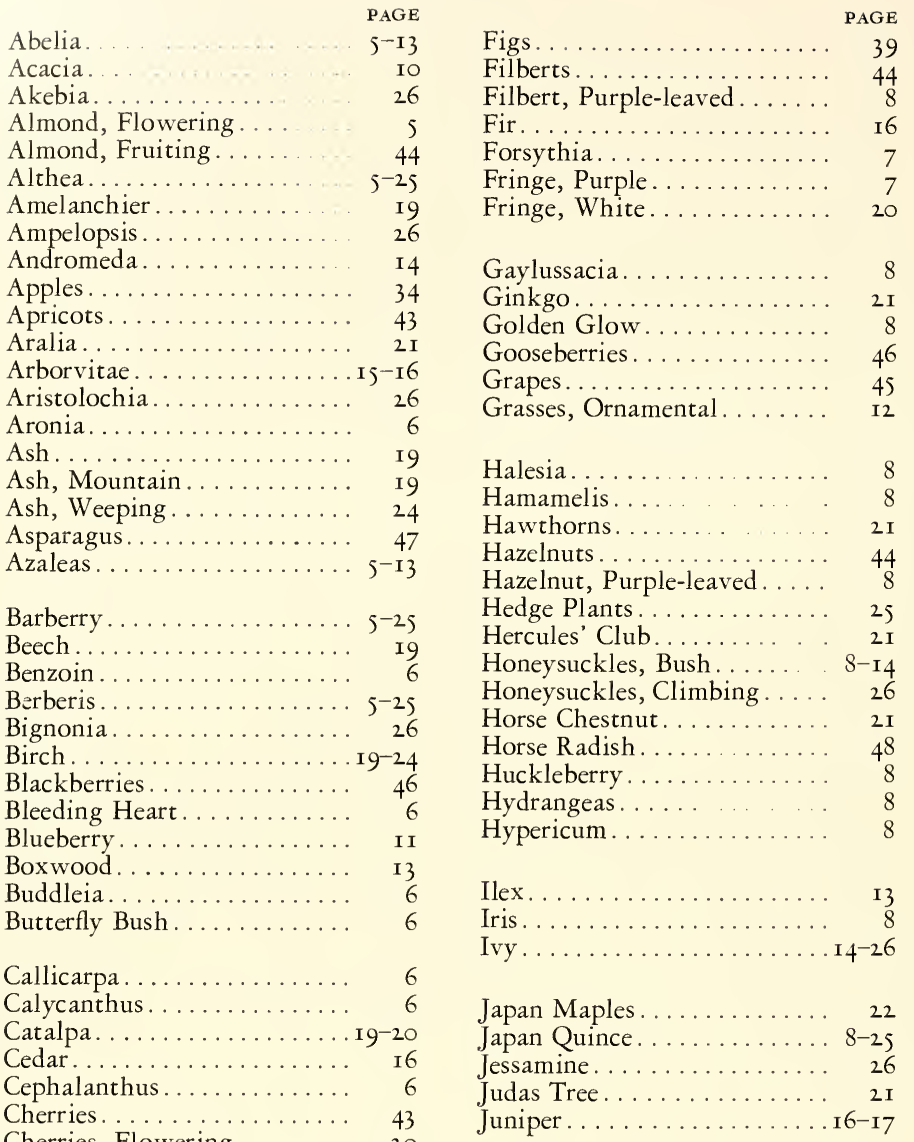

Cherries, Flowering. . . .... 20

Cherries, Weeping........ 24

Clematis.............. 26

Clethra................. 6

Climbing Vines........... 26

Cotoneaster........... I3

Crabapples, Fruiting....... 36

Crabapples, Flowering. ...... 20

Crape Myrtle............ 6

Coralberry............. I0

Cornus, Shrubs . . . . . . . . . 6

Cornus, Trees............. 20

Currants............... 46

Currant, Flowering. . . . . 6

Cydonia Japonica. . . . . . . . . 8

Deutzia

Dicentra. .

Dogwood, Shrubs . . . . . . . .

Dogwood, Trees.

Elder, Golden........... 7

Elm................... 20

Elm, Weeping......... 24

Erianthus............. I2

Eulalia............... I2

Euonymus........... I2

Evergreens.............. Is

Evergreen Shrubs.......... I3-14

Exochorda............. 7
Pachysandra PAGE

Pawlonia.............. 23

Peaches................40-41

Peach, Double-flowering..... 23

Pears................. 38

Peas, Perennial........... I0

Pecans................. 44

Peonies.................. 9

Perennial Peas........... IO

Persimmons............ 4I

Philadelphus........... I0

Pines................ I7

Planes................ 23

Plums............... 42

Plum, Double-flowering.... . 9

Plum, Purple-leaved........ 9

Poplars................ 23

Potentilla............. 9

Privet. ................. 9 9 25

Prunus Pissardii......... 9

Prunus Triloba.......... 9

Quinces.................
Quince, Japan..........

Raspberries............ 47

Raspberry, Flowering. . . . . . IO

Retinosporas........... I7

Rhododendrons .......... I4

Rhodora.............. Io

Rhodotypos............. 8

Rhubarb............. $4^{8}$

Robinia............... I0

Rosa Ludida............. Iо

Rose Acacia..............

Roses................27-33

Rubus odoratus.......... IO

Salisburia.............. 2I

Shade Trees............. 19-23 $^{-23}$

Kalmia.............. I3

Kerria...............

Larch.............. 2 2I

Lathyrus................ IO

Leucothoe............. I4

Lilacs.................

Linden................ 2 2I

Liquidambar............ 23

Locust . . . . . . . . . . . . . IO

Loganberry........... 46

Magnolias............. I4-22

Magnolia Grandiflora...... I 14

Mahonia............... I4

Maidenhair Tree.......... 2I

Maples...............2I-22

Mock Orange............ Io

Mountain Ash............. I9

Mountain Ash, Weeping.... 24

Mountain Laurel.......... 42

Mulberry, Fruiting. . . . . . . 42

Mulberry, Weeping........ 24

Nectarines............ $4_{4}^{\mathrm{I}}$

Nut Trees............. 44

Oaks...............22-23
Shrubs, Deciduous......... . 5 -12 $^{-12}$

Shrubs, Evergreen..........13-14

Silver Bell............... 8

Snowberry............ I0

Spireas.............. II $\mathbf{I}^{-25}$

Snowball............ I2

Spruces............. I7-18-25

Strawberries............ 48

Sweet Gum............ 25

Syringa, Mock Orange..... . IO

Tamarix............... II

Trees, Shade and Ornamental. . 19-23

Trees, Weeping.......... 24

Vaccinium............ II

Viburnum............ I2

Weeping Trees........... 24

Weigela............... I2

Willow . . . . . . . . . . 23 $3^{-24}$

Wineberry............ 46

Wistaria............. 26

Witch Hazel . . . . . . . . . . . . 8

Yew ............... I8

Yucca......... 


\section{Since $185^{\circ}$ \\ A Record of Continuous Service}

In offering this new catalogue, we wish, at the very beginning, to thank those friends that it has been our privilege to serve for many years. The Franklin Davis Nurseries are among the oldest in the country, having been established as far back as 1850 and for more than an average lifetime, they have contributed their products to the gardens and orchards of the South and elsewhere. The continued patronage and friendship that have so long enabled us to serve our customers and friends, is deeply appreciated and give us incentive to redoubled effort in the direction of still better varieties, better quality and service.

At the national exhibition of the American Pomological Society in 1877, we were awarded the Wilder Medal for the largest and finest collection of Apples. We have continued through the years since, to plant all new and promising varieties in our test orchards for trial here. Maryland has become a great Peach and Apple growing state and Virginia Apples are famous for their quality. Realizing that this section on account of favored conditions of soil and climate and with transportation facilities for quickly reaching the consuming markets of great centers of population, will fast grow into a great fruit producing area, we have continued and added to our propagation of the best fruits for this section.

And there is another line of planting that we have given especial attention to, and that is fine ornamental and flowering trees and plants for gardens and landscape planting. We have greatly enlarged our list and we are growing these things at home, for home conditions, able to supply them directly from our own large nurseries in fresh and perfect condition. Those who contemplate the planting of home grounds, whether small or extensive, are invited to visit our office with a display planting of ornamentals, at 629 North Howard Street, Baltimore. It is always a pleasure to help plan the development and beautification of the home grounds.

In this catalogue, we have omitted some varieties that have been replaced by newer, better kinds and offer here one of the most complete collections of really fine things, suited to local conditions and grown right at your door. Those at a distance can be equally certain that plants will be carefully dug and packed in the perfect Franklin Davis way to insure safe arrival and growth.

And in conclusion, we cordially invite your orders and inquiries in person or by letter.

\section{FRANKLIN DAVIS NuRSERIES}

IN COR POR ATED

Offices: 629 North Howard Street, Baltimore, Md.

Nurseries: Mulliken, Md. 


\section{TO CORRESPONDENTS}

IN

the transaction of any business, a mutual desire for mutual satisfaction between parties should prevail. Let us, then, ask of our patrons an observance of the following requests:

That all orders addressed to us be written out in a legible style, and the name in full, that no mistakes may occur. That particular and plain directions be given how they wish their packages marked, and by what route sent, and to whose care consigned. When no route is designated, we will send by the one we deem most advisable; but let it be distinctly understood that we will, in no case, be responsible for any loss or damage that may occur after we have delivered them to the forwarders. They alone are responsible.

While we exercise the greatest care to have all our trees and plants true to name, well-grown and packed in the best possible manner, and hold ourselves in readiness, on proper proof, to replace all trees or plants that may accidentally prove untrue to label, free of charge, or refund the amount paid therefor, it is mutually understood and agreed to between the purchaser and ourselves that our guarantee of genuineness shall in no case make us liable for any sum greater than that originally received for trees or plants that prove untrue. Our reputation for upright dealing, and the uniformly high standard of quality of our products, the result of a 70 years' business career, is our only guarantee to our customers.

When orders are received specifying the kinds wanted, the purchaser will please say whether we shall fill up with other varieties, should some of those which he has ordered be exhausted. We will, so far as in our power, give him his choice; but when the varieties specified cannot all be furnished, or are known to be unworthy of cultivation, we will take the liberty of substituting others in their place, unless special orders are given to the contrary. When the purchaser is not well acquainted with the fruit by name, he would do well to leave the selection to us, briefly stating at what season he wishes the fruit to ripen; and in such case we will exercise our best judgment in making a judicious and profitable selection of the standard sorts and of good trees.

Prompt attention will be given to all letters requesting information, all of which should enclose a postage stamp.

It is expected that orders for trees from those with whom we have no acquaintance will be accompanied with the cash or a suitable reference.

Our terms are INVARIABLY CASH, or satisfactory references.

To all the points where the express companies have an office we can send trees marked C. O. D. This will save the purchaser, as well as ourselves, some trouble.

Trees, plants, etc., will be carefully taken up, each kind tied by itself and labeled, and the roots packed to as to carry safely.

\section{HINTS ON TRANSPLANTING}

THE PROPER SEASON for transplanting fruit trees is during the months of February, March and April in the spring, and October, November and December in the autumn.

THE GROUND SHOULD BE WeLl PREPARED by at least two good plowings; let the subsoil plow follow in the furrow of the other, loosening up the earth to the depth of 12 to I 8 inches. If the ground is not in good condition, it should be made so by the application of plenty of well decomposed manure, or fertilizer of some substantial kind.

Dig the holes SUfFiciently LARGe to admit the roots, giving them their natural position as near as practicable. Use the surface soil for filling in, having it first well pulverized. Avoid deep planting, for it is decidedly injurious to the tree, and, when excessive, may cause its death, or a weak and feeble growth. Plant no deeper than it stood in the nursery.

IMMEDIATELY BEFORE PLANTING, all the bruised or wounded parts should be pared off smoothly; then dip them in a bed of mud, which will coat over every part evenly, and leave no portion in contact with the air, which, accidentally, might not be reached by the earth in filling the hole. If the trees have been out of the ground for a long time, and have become dry and shriveled, they should be immersed in water for 24 hours before planting. Fruit trees sometimes remain with fresh and green branches, but with unswollen buds, till midsummer; instead of watering such at the roots, let the body and branches be wet every evening regularly, about sundown, with a watering pot; this will, in nearly all cases, bring them into active growth.

However Carefully trees MaY Be TAKen UP, they will lose a portion of their roots, and if the whole top is allowed to remain, the demand will be so great upon the roots that in many cases it will prove fatal to the tree. To obviate this, it becomes necessary to shorten-in the branches, which should be done at the time of planting. If the tree has lost the greater part of its roots, a severe shortening-in of the branches will be necessary; if only a small portion of its roots has been cut off, more moderate pruning will be sufficient.

Mulching is another very important matter, particularly in this climate, where we frequently experience severe midsummer droughts. It consists in covering the ground about the tree with a coarse litter, straw, leaves, shavings, or anything that will shade the ground and prevent evaporation. It should be done early in the spring, and will, in most cases, obviate the necessity of watering ar the roots.

Cultivating. - While it is very important to have trees well planted, it is doubly important to have them well cultivated afterwards. Give your trees for a few years a clean, mellow and fertile soil, and they will bend under copious loads of fine fruit, and yield to the cultivator his reward. Dwarf Pears, more than any other trees, require a deep, rich soil, and clean cultivation. In cultivating, great care should be takem not to injure the trees by rubbing the bark off. The best crops for an orchard are those requiring summer culture-such as potatoes, beans, etc.

PRUNING.-We recommend the greatest care and moderation in this operation, believing, as we do, that upon the whole there is more injury done by the use of pruning instruments in unskilled hands than would result from its entire neglect. Some of the objects sought are to diminish the thick growth, to increase the vigor of the branches, to admit light and air, and to form a well-shaped top. Occasional pinching or cropping off of the ends of branches to give the tree proper shape, and removing those that cross or crowd each other, will be all that will be needed by most trees. Peach trees would be greatly benefited by an annual shortening-in of the branches, say onehalf of the previous year's growth; this may be done at any time after the fall of the leaf until the buds.commence swelling in the spring; they never need any thinning out of the branches. Dwarf Pears also need careful attention annually, to keep them in shape, by cutting back the rampant and straggling shoots; they should be pruned down instead of up, never allowing them to grow high, or the top will become too heavy for the roots, and increase the danger of blowing down. 


\section{PROPER AGE AND SIZE OF TREES FOR TRANSPLANTING}

Experience has taught observing planters that a small, young tree, set at the same time, will in a few years overtake and pass a larger one, and continue more vigorous and productive. Large trees are necessarily or unavoidably more injured in digging than small ones. The latter can be moved with their system of roots almost entire. This is another reason why there is less risk in planting small trees.

\section{DISTANCES FOR TRANSPLANTING}

Standard Apple, not less than.

Standard Pear and large-growing Cherry

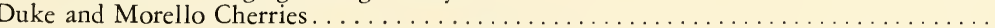

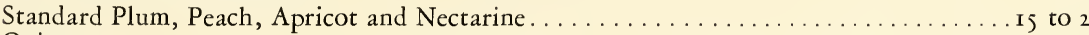

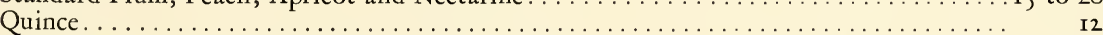

Dwarf Pear, Apple and Cherry

Dwarf Cherries of the Duke and Morello varieties.

Currants, Gooseberries and Raspberries.

Grapes.

Asparagus, field culture.

33 feet apart each way.

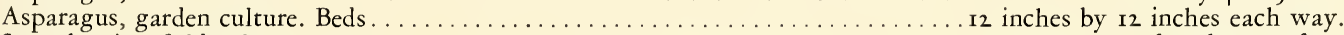

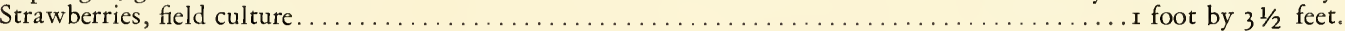

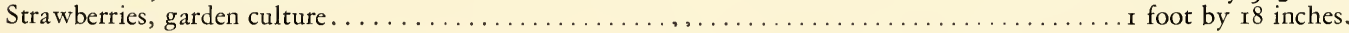

\section{NUMBER OF TREES ON AN ACRE AT VARIOUS DISTANCES}

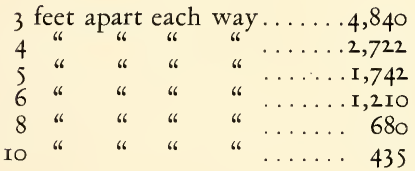

\begin{tabular}{|c|c|c|c|c|}
\hline I2 feet & 6 & " & $\begin{array}{c}\text { Nay } \\
\text { " }\end{array}$ & $\ldots \ldots 302$ \\
\hline 6 & 6 & "6 & "6 & \\
\hline " & " & "6 & "6 & $\mathrm{T}$ \\
\hline " & " & 6 & " & 60 \\
\hline " & 16 & " & " & \\
\hline
\end{tabular}

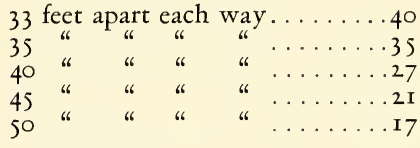

\section{NUMBER OF PLANTS REQUIRED TO PLANT AN ACRE}

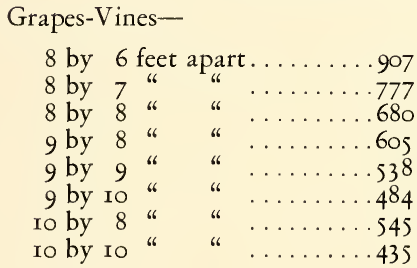

\section{Currants-}

6 by 3 feet apart. . ........2,420

6 by 4

I,8 15

Gooseberries-

6 by 3 feet apart ........2,420

6 by 4 " $" \ldots \ldots \ldots \ldots$ I,8I5

Raspberries-

6 by 3 feet apart ........2,420

7 by 3 " $\ldots \ldots \ldots \ldots 2,075$
Blackberries-

6 by 3 feet apart . . . . . 2, 420 7 by 3 " " .......2, 075

Strawberries-

3 by $1 \frac{1 / 2}{2}$ feet apart. . . . 9, 9,658 $31 / 2$ by $\mathrm{x} 1 / 2$ " " $\ldots .8,260$

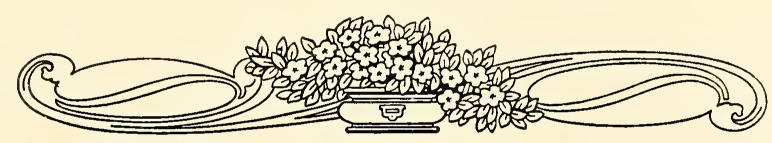




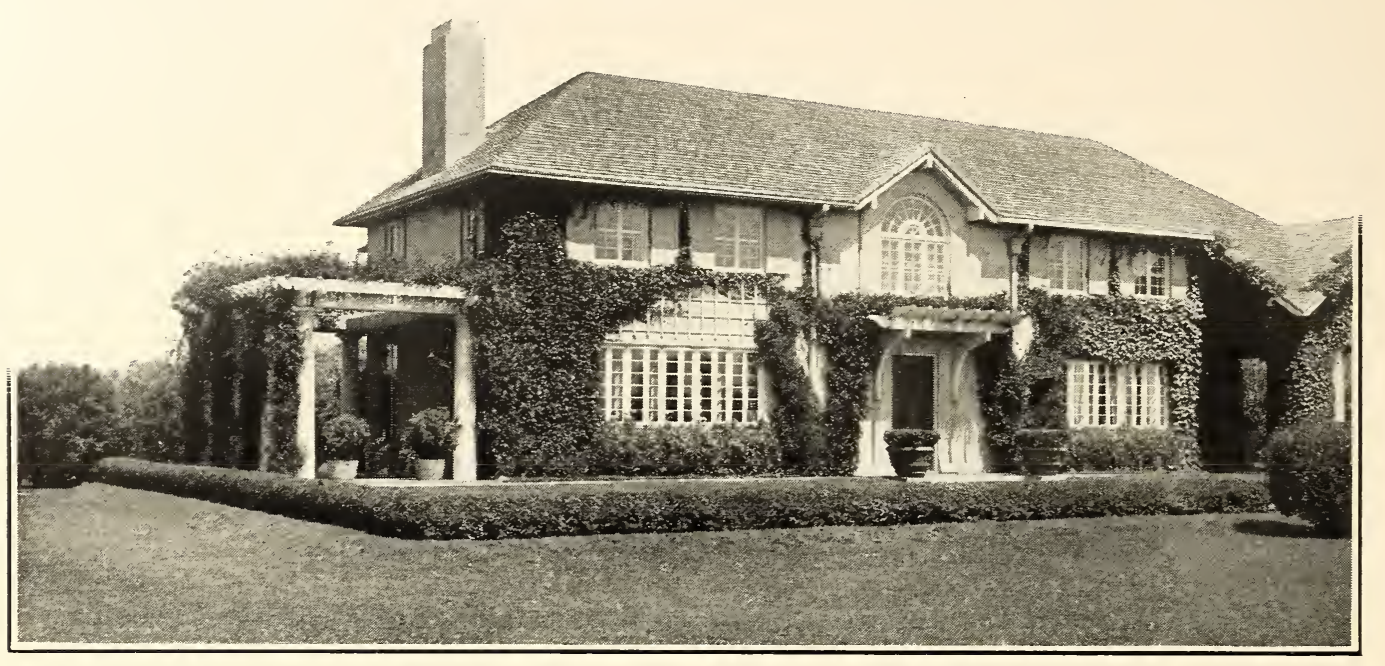

\section{Planting for \\ ORNAMENT AND DECORATION}

TO this department of our business, we are giving increased attention; first, because 1 beautiful trees and plants appeal to us as to others; and second, because there has been a great awakening throughout this country, to the importance and the value of ornamental planting about the home. There is, of course, the practical consideration that shade trees and hedges and beautiful flowering plants add materially to the market value of property. Most advertisements of houses for sale or rent, now include mention of the trees and shrubbery just as they do of the hard-wood floors and baths. And that added value to real estate in five or ten years-or less-is far, far more than the cost of the nursery stock.

And people everywhere are coming to realize the influence of beautiful surroundings, the satisfaction that a beautiful garden gives, the joy of making things grow, of helping nature to produce things of marvelous size and color and fragrance. That is, we are becoming plant and flower lovers-and therefore more cultured and refined as a people.

The demand for ornamental trees and plants has doubled in this country in the last five years; and it is an educated and discriminating demand. Plants are better known; the poor things are being discarded and the better ones selected. That is why we have dropped many varieties from our list, to offer in their place, newer or better ones.

But it is not to be expected that every variety in this or any other catalogue, is going to succeed equally well everywhere. The buyer's location must be considered; even the particular situation into which plants are to go, is important; soil, drainage, exposure and relation to nearby trees and plants, are elements for consideration. And to help our clients with advice based on our intimate knowledge of varieties, we have established a Service Department where we are glad to be consulted about plans or planting problems. Any planting is permanent; its immediate success-the growing and start-off-is important; but even more important is to so select and locate varieties that the ultimate picture will be one of pleasing harmony. To gain that, the advice and assistance of our Service Department is placed at the disposal of our friends. 


\section{Ornamental and Flowering Deciduous Shrubs and Hardy Plants}

REGINNING with the Cydonias and Forsythias in earliest spring and continuing through the summer and until the Hardy Hydrangeas are tinted pink by the cool autumn days, the garden can have, and should have, a succession of flowers through a careful selection of varieties when planting. And thought should be given, where shrubs are planted in groups, to the question of the height of each variety at maturity and the color of the blooms, in order that symmetry of outline and harmony of color may be preserved. We are always glad to have our Landscape Service Department consulted about plans, and to offer suggestions out of our knowledge of varieties.

ALTHEA, or Rose of Sharon. Hibiscus syriacus.-The Altheas bloom in late summer when flowers are scarce. The bushes are neat, upright, compact growers, with ample foliage of good color, and large flowers, singlê, semi-double and double in most colors except yellow.

ALTHEA, 'ADMIRAL DEWEY.-Pure white, very double.

ALTHEA, AMPLISSIMA.--Deep lilac pink with carmine center; double.

ALTHEA, ARDENS.-Bluish purple; double.

ALTHEA, BICOLOR.-Double white with purple center.

ALTHEA, BOULE DE FEU.-Bright red; double.

ALTHEA, DUCHESSE DE BRABANT.-Large, reddishlilac; very double; one of the best.

ALTHEA, VARIEGATED-LEAVED.-Leaves beautifully edged with yellow; purple flowers.

ALTHEA, LADY STANLEY.--White, purple marking at center; double.

ALTHEA, JEANNE D'ARC.--Pure white; double.

ALTHEA, SPECIOSA RUBRA.--Red.

ALTHEA, TOTUS ALBUS.--Pure white; single.

ABELIA GRANDIFLORA.-See Evergreen Shrubs, page I3.

ALMOND, DWARF DOUBLE-FLOWERING. Prunus japonica flore pleno.-Small, very bushy plants that have beautiful, double, rose-like flowers all along the branches in early spring. We have both the Pink and the White.

AZALEAS-Plants that should be better known and more widely planted. They make a great show in the spring, with their brilliant colors. Our native Azaleas are hardy and beautiful and it is encouraging to find them in demand. They are among the best things for our gardens.

AZALEA, AMOENA-See Evergreen Shrubs, page I3.

AZALEA, CANESCENS-A native variety with pretty white flowers, shaded with pink.

AZALEA, GHENT-Very desirable little shrubs with attractive flowers that include nearly every shade of color from white to scarlet.

AZALEA, VISCOSA-Another native plant with white blooms shaded a delicate rose.

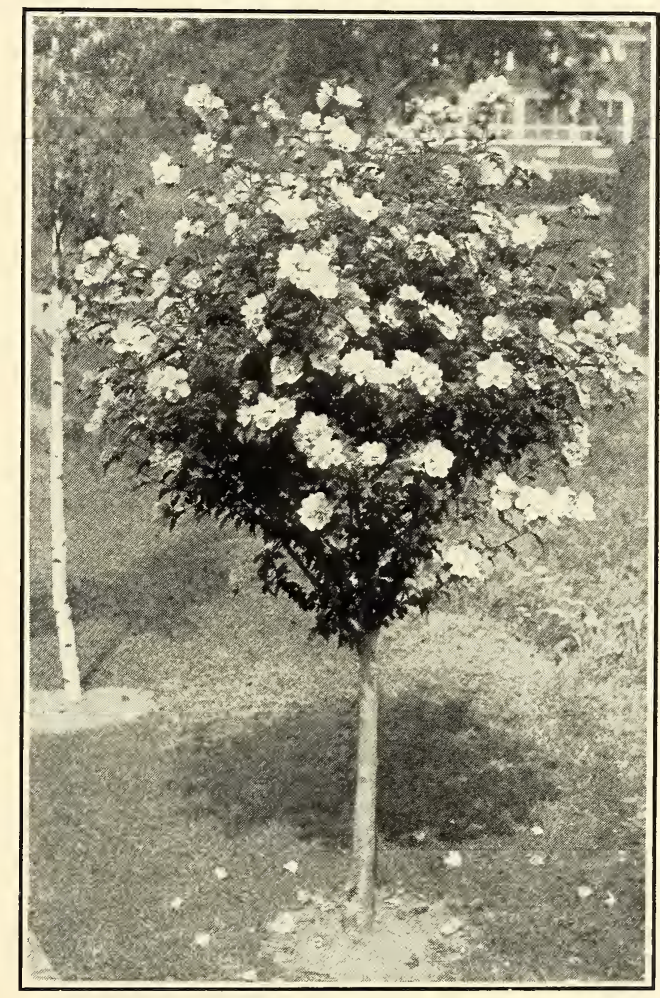

Althea or Rose of Sharon

BARBERRY. Berberis vulgaris-A showy, upright plant with good foliage and bright red berries in autumn.

BARBERRY, PURPLE-LEAVED. B. purpurea-The same, with different colored leaves.

BARBERRY, THUNBERGII. Japanese Barberry-A fine hedge plant, beautiful in every month of the year. The small, abundant leaves are bright green in early spring, turning to darker green in summer and then to red, yellow and gold in autumn. The brilliant scarlet berries hang on till well into winter. Is immune to heat and dust. Does not harbor wheat rust. A hardy, dependable, beautiful shrub. 


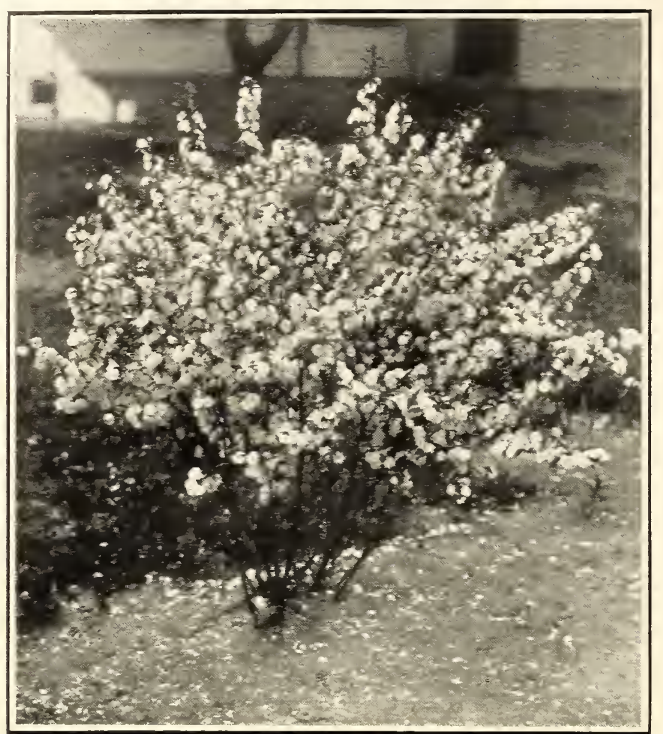

Double-flowering Almond

ARONIA ARBUTIFOLIA. Chokeberry-An attractive shrub with leaves that take on bright autumn tints; has white flowers and bright red berries. Makes a nice massed or group effect.

BENZOIN. Aestivale. Spicewood-Makes a good-sized plant with attractive foliage and with a pleasant, spicy fragrance to the wood; small yellow flowers in advance of leaves, and red berries in late summer.

BLEEDING HEART. Dicentra spectabilis-A perennial plant, dying to the ground in winter but coming up again each spring with a mass of finely cut foliage topped by clusters of pink, heart-shaped flowers. Very hardy and good for borders.

BUDDLEIA. Variabilis Veitchiana, or Butterfly BushOne of the most desirable plants for any section. Makes a strong, bushy growth, throwing numerous long branches that end in flower-spikes a foot or more in length; the flowers are an attractive lilac and very fragrant. Blooms from July until frost; the cool blue when flowers are few, makes this a valuable shrub for Southern gardens. In the North, it is equally good.

CEPHALANTHUS. Occidentalis. Button Bush-A native shrub of strong growth, with handsome leaves and attractive heads of white flowers in early summer.

CALLICARPA PURPUREA-A pretty shrub that makes long branches which are covered their length in autumn, with purple berries.

CALYCANTHUS FLORIDUS. Sweet Shrub-Of good growth, compact, leaves large and glossy and very attractive. The wood has a pleasant odor. The flowers are double, chocolate-colored and deliciously fragrant. A native plant known all through the South and yet hardy also in the North.
CRAPE MYRTLE. Lagerstroemia indica-The Crape Myrtle is to the South what the Lilac is to the North. It makes a nice shrub; in time, it grows inco a goodsized tree. The leaves are small but ample and the blooms are borne in immense spikes of fluffy daintiness and charming color. Very easily grown. We have $P$ ink, Purple, Scarlet and Wbite. The White is not so robust a grower as the others.

CORNUS ALBA. Dogwood-A shrub of bushy habit, that should be cut to the ground each spring; it will throw out twice as many shoots. The flowers are white and come in early June; but the great beauty of the plant is in its branches which turn a blood-red color in winter, affording a charming contrast to its surroundings.

CORNUS AUREA-Similar, with bright yellow wood.

CLETHRA ALNIFOLIA. Sweet Pepper Bush-Dwarf and bushy, with numerous spikes of dainty white flowers in mid-summer; very fragrant. Desirable for its small, compact size and for its blooming season.

CURRANT, RED-FLOWERING. Ribes sanguineumSmall, deep red flowers in early spring.

CURRANT, YELLOW-FLOWERING. R. aureumBright, shining leaves and small yellow flowers in spring.

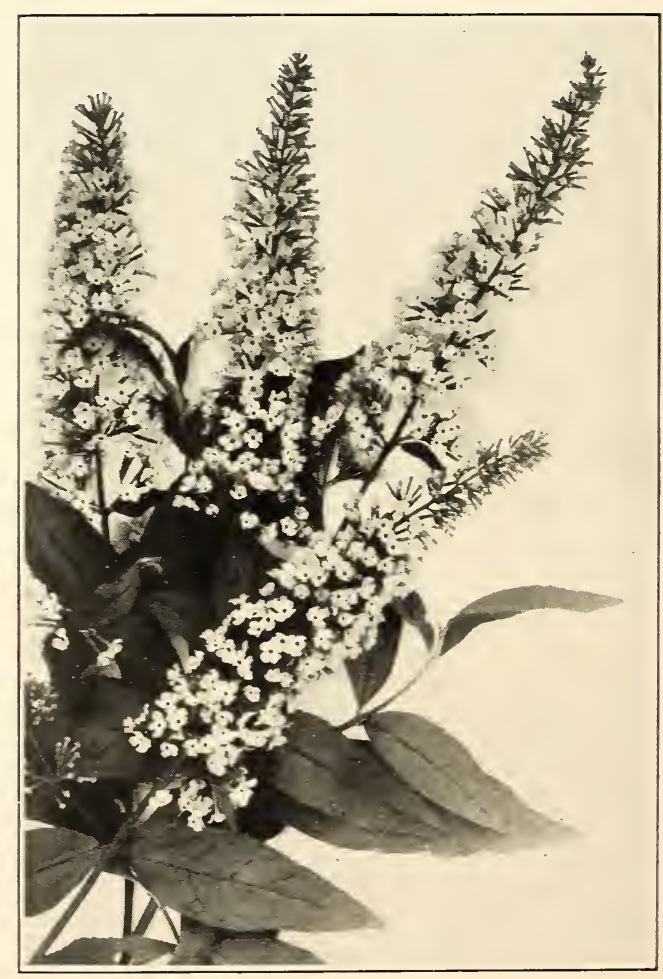

Buddleia or Butterfly Bush

One of the best shrubs, furnishing an abundance of blue, fragrant flowers during summer and autumn 


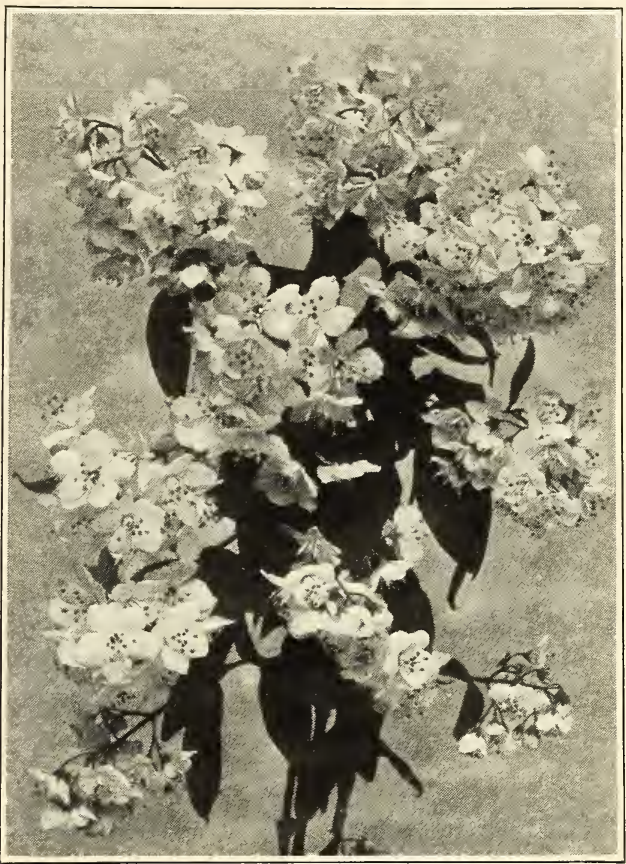

Deutzia Lemoineii

DEUTZIAS - Valuable plants originally from Japan, equally at home North and South and everywhere appreciated for their beauty, their hardiness and their many fine qualities. The growth is upright in most varieties, the wood strong and thick, the leaves slightly rough but abundant and of good color. The flowers are borne in racemes of 4 to 6 inches and are dainty and beautiful. They are all white, some with touches of color in the outside of the petals.

DEUTZIA, CANDIDISSIMA-Pure white, very double.

DEUTZIA, GRACILIS-Slender branched. Dwarf, with slender, drooping branches, making a round, bushy little plant that produces a great profusion of fine, pure white, single flowers in spring. Its small size, good shape and extreme floriferousness, make this a most valuable plant.

DEUTZIA, CRENATA DOUBLE-Very double white flowers whose outer petals are delicately marked with pink. Desirable in every way.

DEUTZIA, CRENATA, DOUBLE WHITE-Similar to the last, but with double white flowers without any color added.

DEUTZIA, FORTUNEII-Strong and upright in growth, with rich, dark green leaves and a great abundance of large, single flowers. One of the most popular shrubs we grow. Does well anywhere.

DEUTZIA, LEMOINEII-An especially fine variety. Somewhat like Gracilis but of larger and more spreading growth; much more vigorous, with the same wealth of beautiful white flowers.
DEUTZIA, PRIDE OF ROCHESTER-White flowers with outer petals margined with pink; an especially strong and vigorous grower; blooms early and is highly recommended for hardiness, vigor and blooming habit.

ELDER, GOLDEN. Sambucus Aurea-Rather spreading in habit with flat panicles of whire blossoms in spring. Grown largely for its foliage which, green at first, soon takes on a golden yellow color that is very conspicuous.

EXOCHORDA GRANDIFLORA. Pearl Bush-Large, pure white flowers in May; a shrub that makes a fine growth and spreads to an equal measure; its fine show of white bloom in spring is most attractive.

FORSYTHIA. Golden Bell-Among the first shrubs to bloom in the early spring. All have small, star-like yellow flowers before the leaves are out.

FORSYTHIA, FORTUNEII-Upright growth and golden yellow flowers.

FORSYTHIA, INTERMEDIA-The earliest and most abundant bloomer.

FORSYTHIA, SIEBOLDII-Blooms early and profusely. FORSYTHIA, SUSPENSA - Of weeping habit; will climb on walls if stapled; the effect is fine.

FORSYTHIA, VIRIDISSIMA-Very dark green leaves and green wood.

FRINGE, PURPLE. Rhus cotinus-Smoke Tree-Makes a small tree and when in bloom, the purplish, hair-like flowers, covering the entire tree, give it the appearance of being enveloped in smoke. Very odd and unusual.

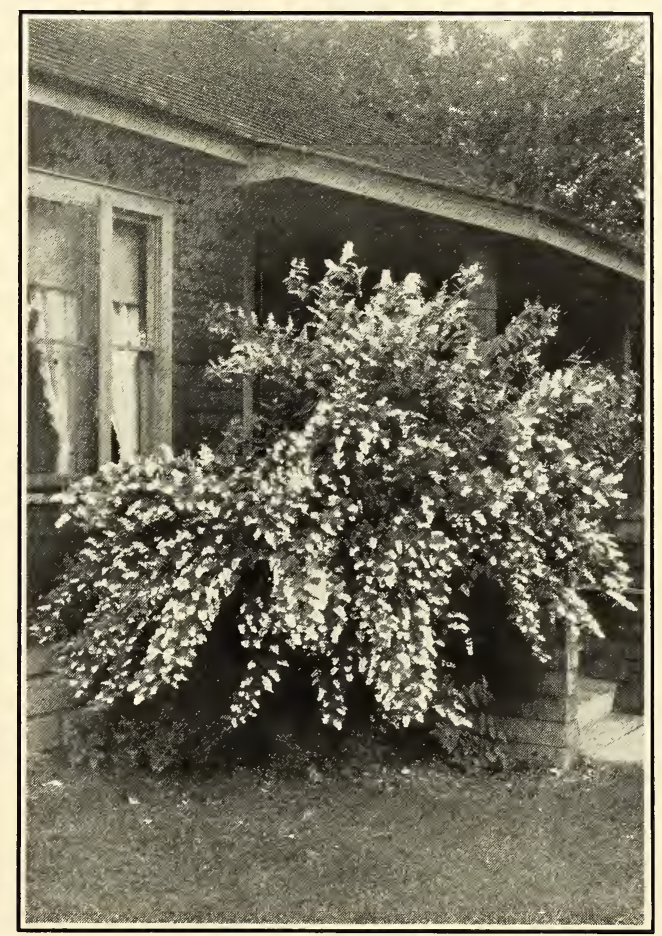

Deutzia Pride of Rocbester 
GAYLUSSACIA RESINOSA. Black Huckleberry-A hardy native shrub of about three feet, with ornamental, yellowish-green leares, reddish flowers and small blue-black berries.

GOLDEN GLOW. Rudbeckia laciniata-A hardy perennial plant that grows about 5 or 6 feet high and bears an abundance of rery double, chrysanthemumlike yellow flowers in summer. Grows with little care and once established, furnishes an endless amount of bloom. Good for massing or, on account of its rather tall growth, for backgrounds or along fences.

HALESIA TETRAPTERA-Snowdrop, or Silver Bell. Small, bell-shaped, white flowers in spring; very attractire.

HAMAMELIS, VIRGINICA. Wirch Hazel-A tall shrub with yellow flowers and raluable because it blooms in autumn just before the leares fall.

HAZELNUT, PURPLE-LEAVED. Corylus arellana atropurpurea-A rery attractive shrub with large purple leares.

HYPERICUM AUREUM - A shrubby hardy perennial plant with good foliage and very attractive single cupshaped golden rellow flowers from July till October. Fine for foliage and bloom.

BUSH HONEYSUCKLES. Lonicera-These are not the Climbing Honeysuckles, but they form a valuable group of hardy shrubs with small fragrant flowers and colored berries, both attractive. They make good hedges. The foliage is rich and abundant and the berries are reminder that the beauty of berry-bearing plants is apt to be orerlooked. They are valuable plants and should be more largely used. All are bushes of upright growth.

HONEYSUCKLE, FRAGRANTISSIMA-Small, creamcolored flowers of great fragrance; good foliage and almost erergreen.

HONEYSUCKLE, TARTARIAN PINK-Small, rosecolored flowers; rery hardy.

HONEYSUCKLE, TARTARIAN WHITE-Similar, with white flowers.

HONEYSLCKLE, MORROWI-Rather bushy, with fine, round leares which corer the branches, making it desirable for hedging. It bears shearing well.

HYDRANGEA, OAK-LEAVED-White flowers, changing to purple; more prized for its very large leares of dark green, turning to crimson in autumn. Fine for massing or bordering shrub plantings.

HYDRANGEA, PANICULATA GRANDIFLORA-One of the finest flowering shrubs, of great hardiness, strong growth and beautiful blooms. The flowers are borne at the end of new growths in immense heads of pure white; they are very lasting and in autumn take on a pink tinge; cut and taken indoors, they dry without losing substance or color and make attractive house decorations in winter. Valuable as the best and showiest of the late-blooming shrubs.

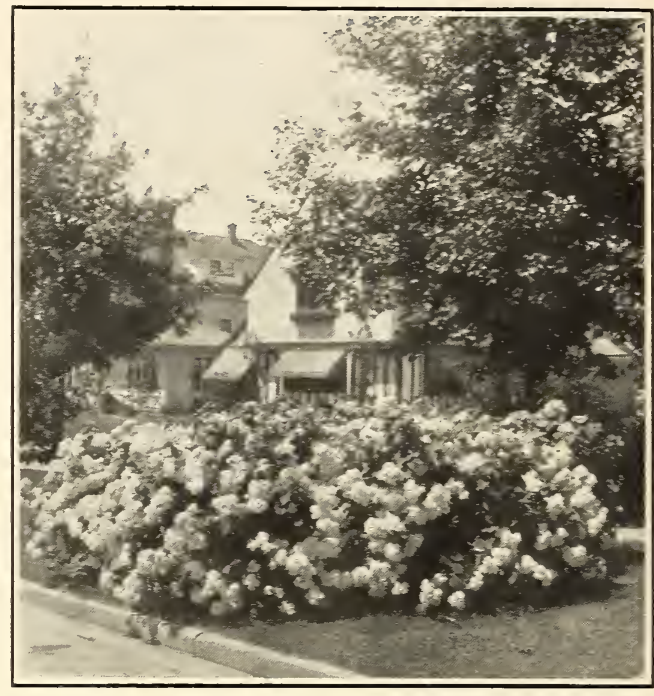

Hydrangea Arborescens Grandifora

HYDRANGEA, TREE, or STANDARD FORM-The last named variety can also be supplied with good heads on single straight stems, in tree form.

HYDRANGEA, ARBORESCENS GRANDIFLORAHills of Snow, or American Erer-blooming Hydrangea. Balls of pure white flowers from July till frost.

HYDRANGEA, THOMAS HOGG-A rariety of great beauty that is soft-rrooded and therefore not hardy, but needs to be taken indoors or else entirely and warm1y covered for winter. Large heads of pure white, waxy flowers.

HYDRANGEA, OTAKSA-Like the foregoing, but with pink flowers.

IRIS KAEMPFERII or Japanese Iris-Hardy perennial plants with flowers the largest of any Iris, often measuring 6 to 8 inches across. The colors are mostly white and purple with variations and shadings of great rariety. Ther need rich soil and sunlight.

JAPAN QUINCE. Cydonia japonica-One of the earliest shrubs to bloom in spring; the flowers, of dazzling scarlet, cover the plant before the leares are out. Just the touch of warmth and color needed in very early spring.

KERRIA JAPONICA-A rery pretty plant, not growing very tall, but branching hearily and bending gracefully; dainty leares of rich green and bright yellow double flowers over a period of several months.

KERRIA, WHITE. Rhodotypus Kerrioides-An attractive shrub that grows + to 6 feet high, with beautiful yellowish-green foliage and large, single white flowers late in May. The black seeds that follow, are large and showy. 


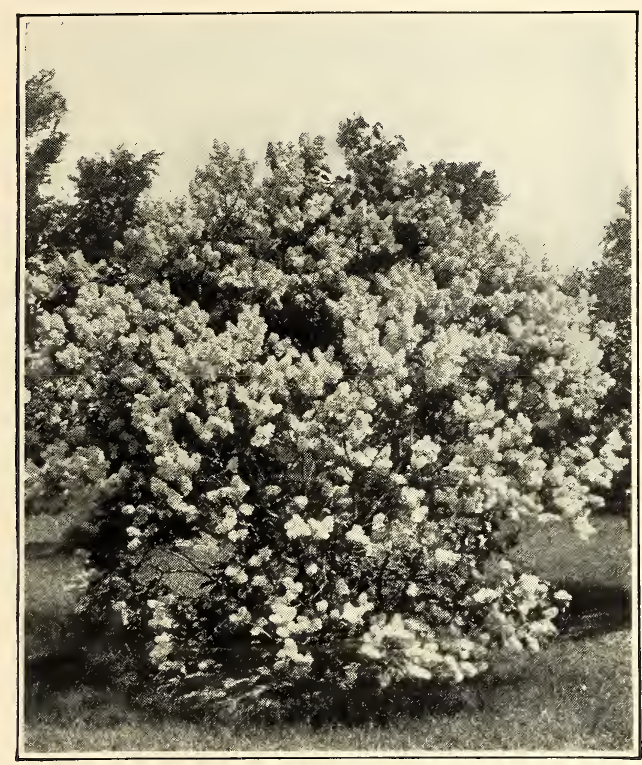

Lilac, Single Purple

LILACS. Syringa-The newer hybrids are marvelously beautiful and far ahead of the old-fashioned types a former generation knew.

LILAC, CHARLES X.-Single; large, loose trusses of reddish purple.

LILAC, JOSIKAEA-A distinct species, inclined to grow in tree form, with dark shining leaves; single purple flowers after the other lilacs have done blooming and followed only by Villosa.

LILAC, PRESIDENT GREVY-Distinct; one of the few blue Lilacs; double.

LILAC, PURPLE-The well-known single, bluishpurple Lilac of our grandmothers' gardens.

LILAC, ROTHOMAGENSIS RUBRA-Very distinct, with immense panicles of single, reddish flowers.

LILAC, SANGEANA - Purplish red; very fine.

LILAC, SOUVENIR DE LUDWIG SPAETH-Immense panicles of large, single, dark purplish red flowers. Very striking and distinct.

LILAC, VILLOSA-A distinct species with flowers light purple in bud, but white when open; fragrant; especially valuable as it blooms fully two weeks after the hybrid Lilacs are gone.

LILAC, WHITE-The old-fashioned White Lilac, single, fragrant and always a favorite.

LILAC, WHITE PERSIAN-Single white in loose trusses; very fragrant, dainty and refined.

PAEONIAS-These extremely hardy herbaceous plants all produce flowers of great size and beauty in a wide range of color from pure white to darkest crimson, blooming in June. After the blooms are gone, the foliage is still an attraction. Gorgeous plants that are superb in cold and temperate climates. We offer a good assortment of colors in the best varieties.
PLUM, DOUBLE-FLOWERING. Prunus Triloba-An attractive hardy shrub that bears small, semi-double pink flowers closely set all along its branches.

PLUM, PURPLE-LEAVED. P. pissardi-Makes a large shrub or small tree, very upright and handsome in form; the leaves, at first red, change to deep purple and the color is not affected by the hot sun. One of the most satisfactory of the colored-leaved shrubs.

POTENTILLA FRUTICOSA-A small shrub with odd, silky foliage and yellow flowers in summer; a good plant for bordering groups of taller shrubs.

PRIVET-The Privets, or Ligustrums, all make very neat, compact plants with fine, rich green leaves in abundance; they are especially good for making hedges, being all the better for frequent clipping, can be held at any height and in regular forms with smooth edges. A Privet hedge can be had with a surface as smooth as a board. Most varieties are almost evergreen. Unsheared and in their natural growth, they produce delicate white flowers in June and July, that are very sweet.

PRIVET, AMUR RIVER-Hardy Northern type. Similar in habit and form to the well-known California Privet, with leaves not so lustrous but hardier and better suited to severe Northern winters.

PRIVET, CALIFORNIA OVALIFOLIUM - Vigorous and upright, with thick rich, dark green leaves and nearly evergreen; makes a beautiful hedge; one of the best. We can supply California Privet in fine specimen plants trained into Globe shape and in Standard form: on single stems with round heads; suitable for formal garden effects.

PRIVET, IBOTA-Spreading and tall-growing with greyish green leaves and black berries. Very hardy.

PRIVET, VARIEGATED-LEAVED-A small growing variety with leaves attractively margined with yellow.

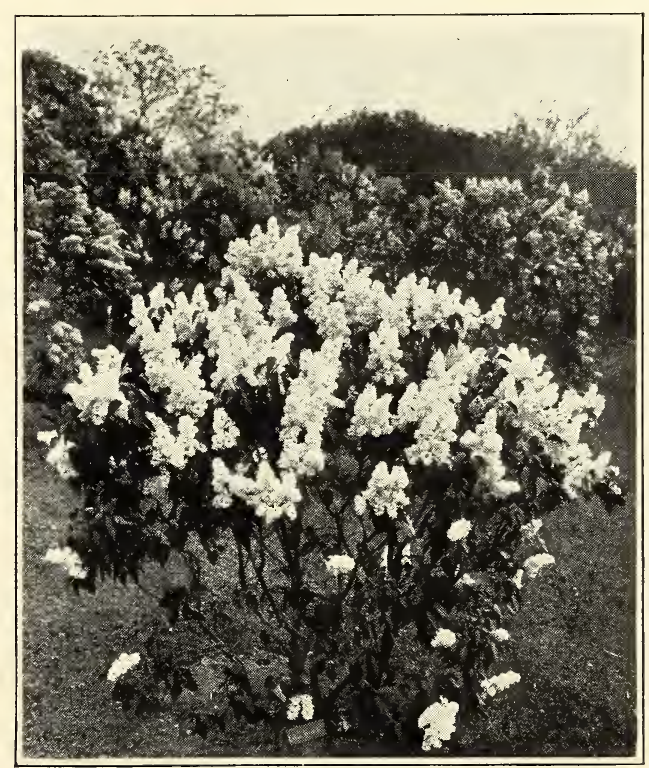

Lilac, Double White 


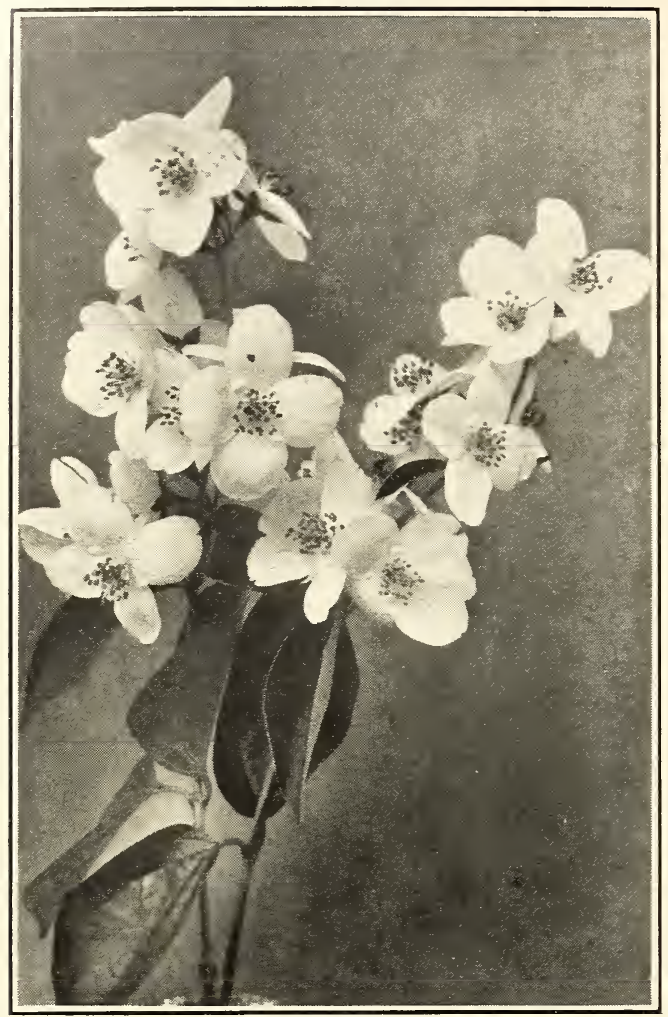

PHILADELPHUS or SYRINGA. Mock Orange-All the varieties in this group have white flowers in June, immediately after the Weigelas. Except a few dwarf kinds, they are all strong growers, attaining ultimately a height of Io to 12 feet, sometimes as much as I5 feet. The leaves are good, the plants are rather spreading, all are hardy and no collection of good shrubs is complete without at least some of the beautiful "Mock Oranges."

PHILADELPHUS DOUBLE - FLOWERING - Small, semi-double, fragrant flowers.

PHILADELPHUS, AUREUS-Golden-leaved. A dwarf variety with golden-yellow leaves and single white flowers. Especially good for planting at the edge of groups for contrast.

PHILADELPHUS, CORONARIUS--Garland Syringa. Pure white, single, highly scented flowers.

PHILADELPHUS, GORDONIANUS-A very strong grower; single flowers, slightly fragrant; valuable for late blooming.

PHILADELPHUS, GRANDIFLORUS - Tall-growing, with exceptionally large, single flowers.

PHILADELPHUS, LEMOINEII ERECTUS-Erect and bushy with very sweet single flowers in clusters. Grows to 5 or 6 feet.

PERENNIAL PEA. Lathyrus latifolius-Similar to the Sweet Peas, but hardy and perennial with pink and white flowers in clusters.
RHODORA CANADENSIS-A small, hardy shrub of two to three feet, with attractive foliage and rosypurple flowers in April and May.

ROSA LUCIDA-A Rose species with abundant small leaves and very pretty single pink flowers; excellent for working in with shrub groups. Very hardy.

ROSE ACACIA, or Moss Locust. Robinia hispida-A native shrub of sprawling growth, with good foliage and producing in June and at intervals through the summer, drooping clusters of rose-colored flowers.

RUBUS ODORATUS. Flowering Raspberry-A valuable shrub. The leaves are very large and last through the summer, unaffected by heat or dust; the flowers are large, single and a pinkish lavender; very attractive. Invaluable for its abundant foliage and its fresh appearance in the hottest summer.

SNOWBERRY. Symphoricarpos Racemosus-Small flowers in summer and then, great quantities of milkywhite fruits of great beauty. One of the best berrybearing shrubs.

SYMPHORICARPOS VULGARIS. Coralberry-Grows vigorously and quickly into a nice, spreading shrub whose long branches are covered in autumn with coralred berries. The beauty of these berried plants should not be overlooked.

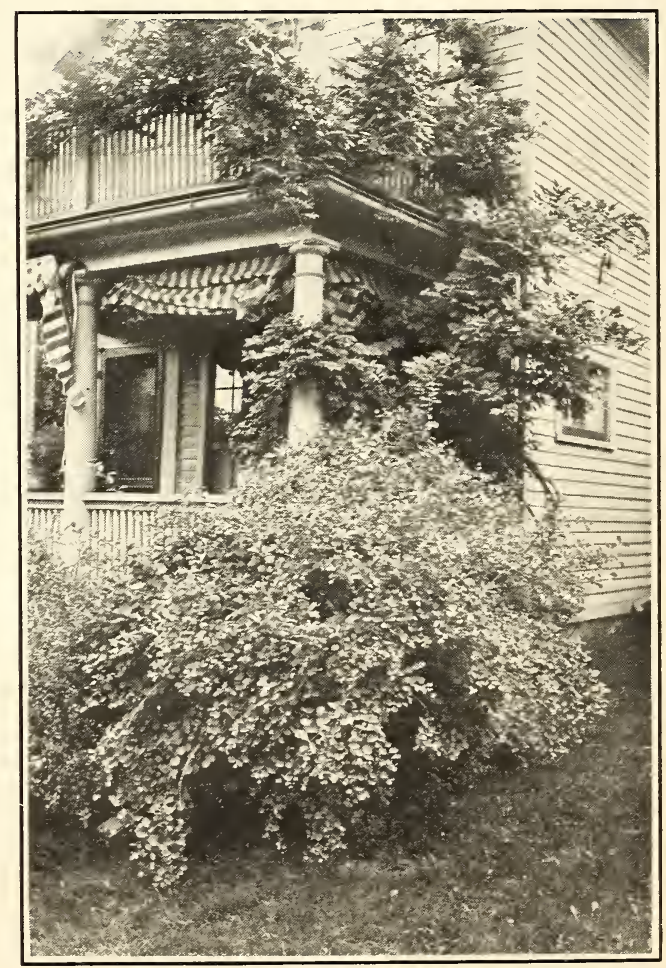

A porch corner made attractive with a planting of Wisteria and White Snowberry, whose berries will add beauty to the scene until winter. 
SPIREAS-Beautiful shrubs of the easiest culture; of many types and forms, all of them good.

SPIREA, ANTHONY WATERER-Dwarf, compact and bushy with flar heads of crimson flowers. Blooms all summer and fall. Most desirable.

SPIREA, BILLARDII-Blooms nearly all summer; bright, rose-colored flowers on spikes.

SPIREA, BILLARDII ALBA-Similar to the last named, but with spikes of white flowers.

SPIREA, CALLOSA-A fine, dwarf variety with good foliage and flat panicles of light pink flowers all summer.

SPIREA, CALLOSA ALBA-Like the foregoing, but with white flowers.

SPIREA, DOUGLASII-Tall and upright, with long spikes of beautiful deep rose-colored flowers.

SPIREA, FROEBELLI-A fine variety with rosy-pink flowers in flat heads from early spring on. The young leaves, dark red, are artractive.

SPIREA, GOLDEN-LEAVED. S. opulifolia aurea-A form of Spirea Opulifolia, with leaves at first light green, then golden yellow; makes a very strong, upright bush of considerable size. Very vigorous and hardy. Has white flowers but most prized for the golden foliage.

SPIREA, PRUNIFOLIA-Bridal Wreath of the North; blooms very early, the diminutive very double, white rose-like flowers literally covering the branches; the first to bloom.

SPIREA, REEVESII-Double-flowering. One of the handsomest, with small, double flowers in small heads of bloom along the drooping branches.

SPIREA, THUNBERGII-Dwarf, compact, with abundant and attractive small, narrow leaves and pretty small white flowers. Fine for edging groups, or for hedging.

SPIREA, TOMENTOSA-Low-growing, with numerous spikes of pale pink flowers.

SPIREA, VAN HOUTTE-The finest of all the spireas, perfectly hardy and at home anywhere; blooms in wonderful profusion in spring, the single white flowers in flat heads being closely clustered along the whole branch; of decidedly drooping habit, giving the plant the appearance of a fountain, of white loveliness. We cannot too highly recommend this variety as a single plant, for grouping or for hedging.

TAMARIX-Beautiful shrubs with thread-like foliage and delicate small flowers in spikes. Invaluable for sea-shore planting.

TAMARIX, AFRICANA-Tall and spreading, with rosy-purple flowers.

TAMARIX, TETRANDA-Smaller, with pale pink flowers in late summer.

VACCINIUM CORYMBOSUM-The Common Blueberry. Low-growing, bushy planrs that yield the "makings" of those cherished blueberry pies.

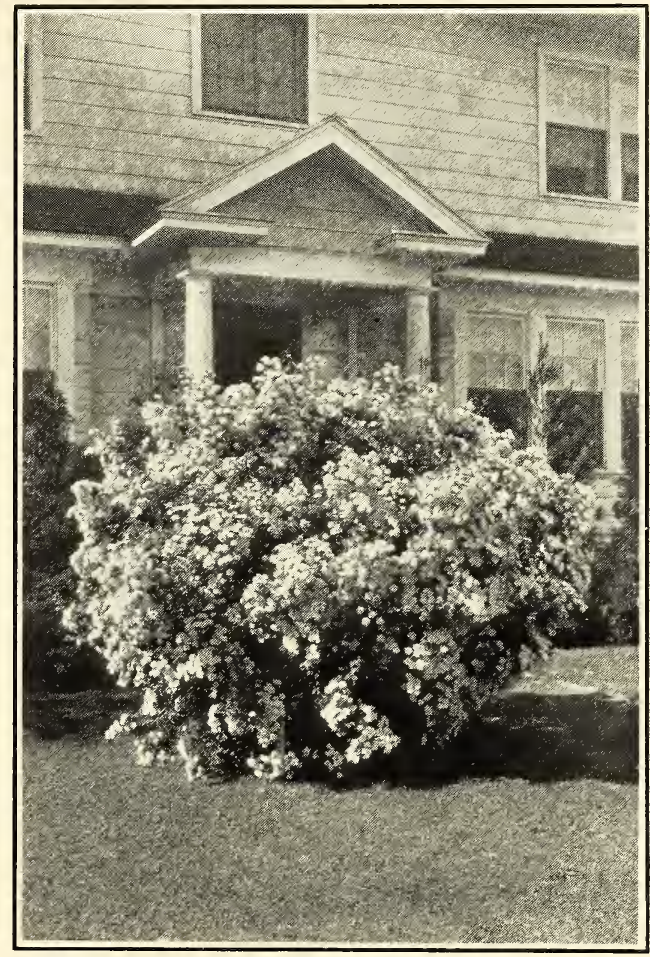

Spirea Van Houttei

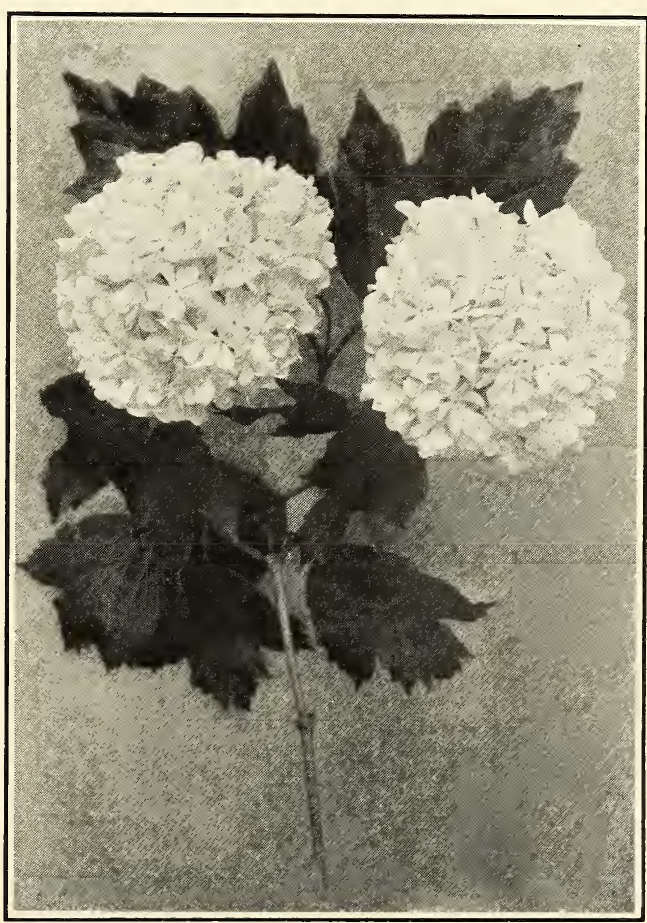

Common Snowball 


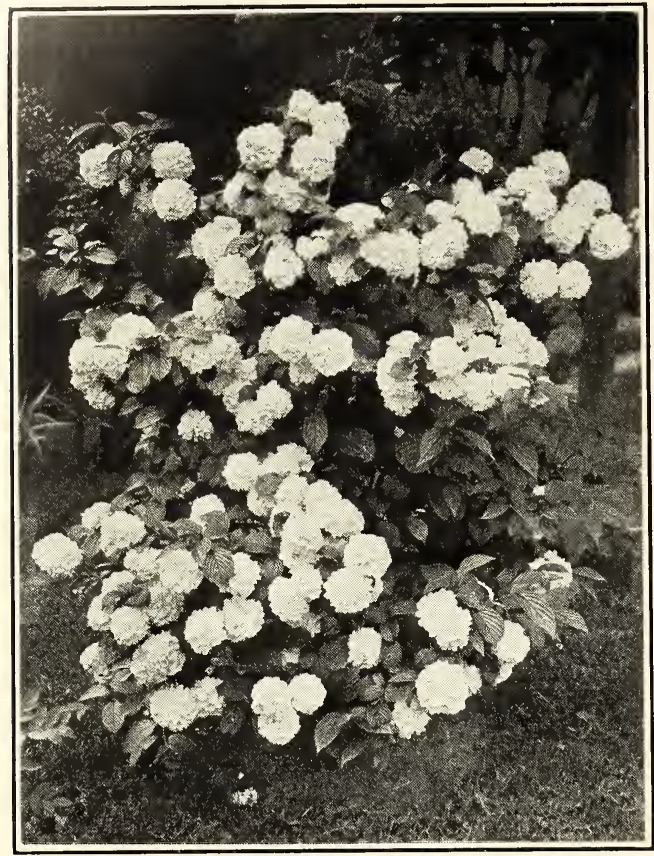

Viburnum Plicatum - Japanese Snowball

VIBURNUM CASSINOIDES-With fine, rich, dark green leaves and white flowers followed by red berries. The leaves color up in autumn.

VIBURNUM DENTATUM. Arrowwood-Dark green leaves, heavily ribbed, taking on rich red and purple shades in autumn; white flowers and dark blue berries.

VIBURNUM LANTANA. Wayfaring Tree-White flowers in clusters in early spring, followed by red berries that later turn black. Grows well in dry places.

VIBURNUM LENTAGO. Nanny Berry-Very vigorous; white flowers and black berries that hang long.

VIBURNUM OPULUS-High Bush Cranberry. Grows to 8 or ro feet, has handsome, dense, brilliant green foliage, a rich setting for the large bunches of brilliant crimson berries that brighten the late summer and autumn days. VIBURNUM OPULUS STERILIS-Common Snowball. Lovely balls of double white flowers the last of May.

VIBURNUM PLICATUM. Japanese Snowball-With fine, dark-green ribbed leaves of great beauty, and balls of waxy, pure white flowers. A variety of great beauty.

VIBURNUM PRUNIFOLIUM. Black Haw-Strong growing into tree-form; good foliage that takes on all the brilliant autumn colors; the black fruits are edible.

VIBURNUM PUBESCENS -Slender, upright branches making a compact plant of three to six feet; blooms in June and July, followed by almost black fruit.

YUCCA. Filamentosa-Hardy and easily grown; a tropical-looking plant with a low mound of long, narrow leaves, above which rises, in July, a tall stem whose top is surmounted by an immense pyramid of creamywhite flowers. The Yucca leaves are evergreen and on that account alone, it is a most valuable plant.
WEIGELAS-Hardy, easily grown and great bloomers. Most varieties are of erect growth when young, later spreading out with a tendency to droop gracefully. They produce, in June and July, beautiful trumpetshaped flowers in large clusters along the branches. They range from pure white, through pink and rose, to dark red. The Weigelas bloom just as the Lilacs are gone.

WEIGELA, CANDIDA-Pure white flowers.

WEIGELA, EVA RATHKE-Sprawling and irregular; flowers brilliant crimson; the best red one.

WEIGELA, HENDERSONII-Light pink flowers with red on the outside of the petals; compact and shapely.

WEIGELA, ROSEA-All considered, the finest of the group; a strong bush, flowering profusely, with delicate rosy-pink blooms.

WEIGELA, VARIEGATED-LEAVED-Light pink flowers and leaves margined with yellow.

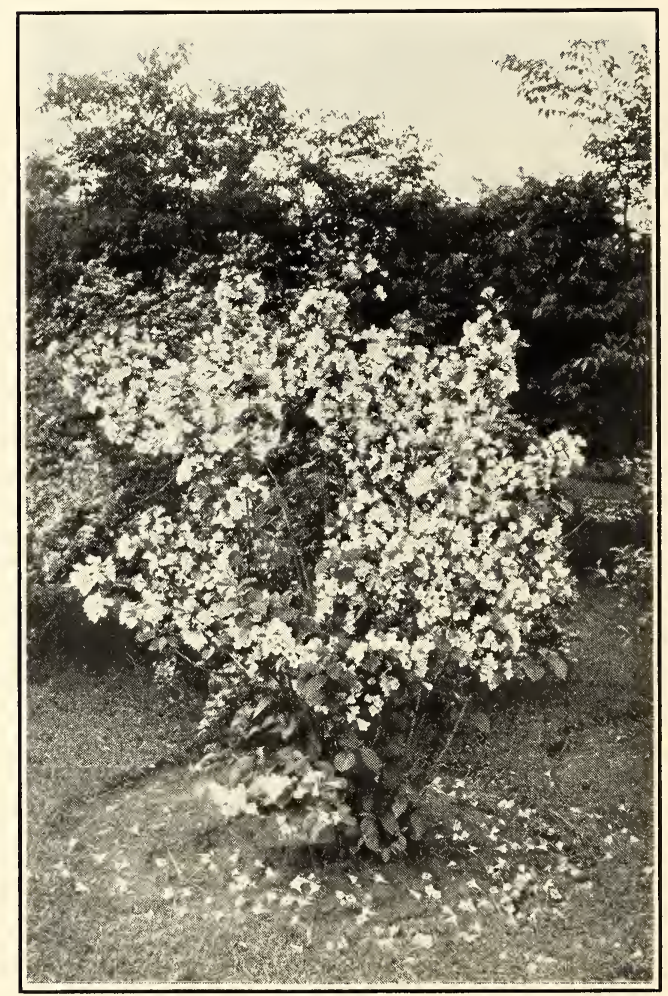

Weigela Rosea

ORNAMENTAL GRASSES-These are useful for massing or for centering groups; they are highly ornamental. EULALIA, JAPONICA VARIEGATA-Leaves handsomely striped.

EULALIA, JAPONICA ZABRINA-One of the most ornamental of the fancy grasses, the leaves being marked crosswise with bands of white and green.

ERIANTHUS RAVENNAE-Green and tall-growing, with large plumes. 


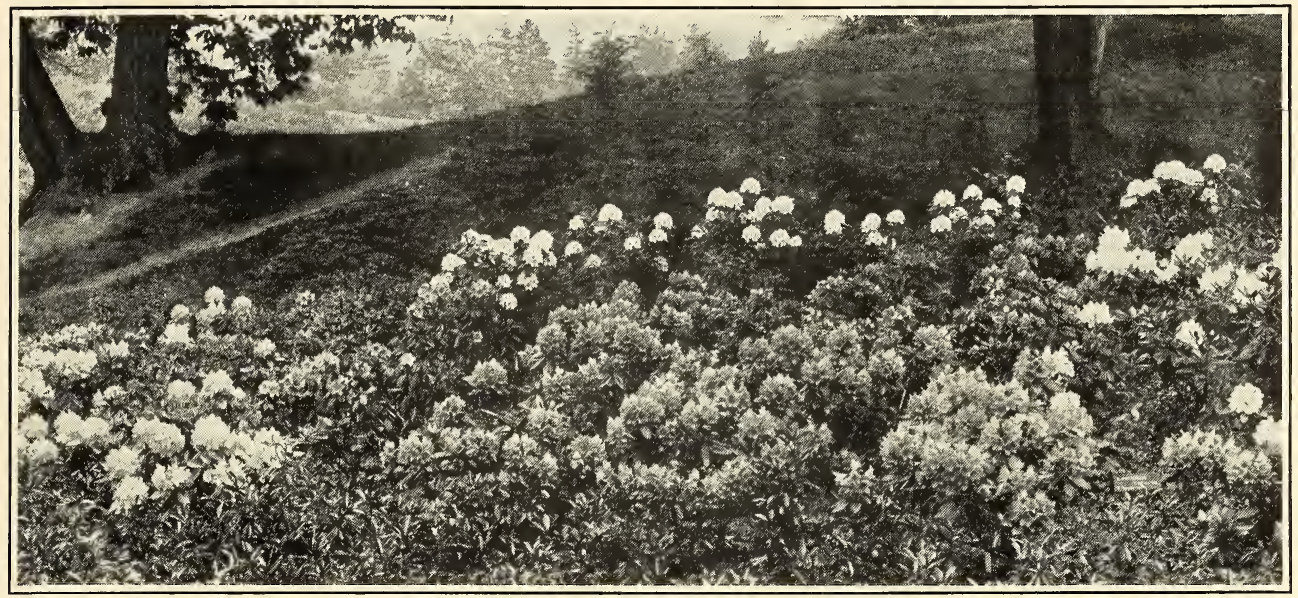

A planting of Rhododendrons, Kalmias and Azaleas

\section{Broad-leaved Evergreen Shrubs}

TO group of plants is more valuable, none more beautiful and none more especially adapted to our section than the Broad-leaved Evergreens, or Evergreen Shrubs, many of which are native here and all of which grow to finer perfection right here, than anywhere else. We are giving increasing attention to these plants because of their beauty and growing popularity. They have been too long neglected.

ABELIA, GRANDIFLORA-Marvellously combines beauty of foliage and beauty of bloom; the small, dark green, shiny leaves are immune to heat and dust, always retaining their fresh and glossy appearance through the summer; in winter, they turn to a bronze. The flowers are white, small and trumpet-shaped, sweet scented and borne in large clusters. Highly recommended for this section.

AZALEA, AMOENA-Small, bushy plants with evergreen foliage and great masses of rich, pink blooms in early spring.

AZALEA, HINODEGIRI-Small evergreen shrubs that literally cover themselves in early spring with brilliant red flowers. There is no showier plant in the garden.

COTONEASTER-Small, bushy, low growing plants with small, shiny evergreen leaves and red berries that hang into winter. They fit well into rockeries or borders of evergreen groups.

BOXWOOD. Buxus Sempervirens-A handsome shrub with deep green leaves, succeeding well in sun or shade. The old-fashioned Boxwood.

BOXWOOD, DWARF. B. Suffruticosa-Makes a pretty little shrub when planted singly, but is the very best of all for diminutive hedges-or for edging.

EUONYMUS JAPONICUS-Large leaves of waxy dark green; makes a nice plant in the garden or can be used for a small hedge.
EUONYMUS JAPONICUS, ARGENTEA—Leaves bordered with silver.

EUONYMUS JAPONICUS, AUREUS-Golden-variegated leaves.

EUONYMUS, RADICANS-A vine, very hardy and evergreen; clinging and used for covering either stone or ground, or trained on walls.

EUONYMUS, RADICANS VEGETUS-Very desirable; hardy; clings to stone or brick; has rich, green leaves and bright red berries in winter. Highly recommended.

EUONYMUS, SIEBOLDI-Almost evergreen, not quite; but valuable and always satisfactory. Makes a nice, bushy shrub with tendency to climb if support offers. A decided charm is the numerous red berries that last well into winter.

ILEX GLABRA. Winterberry-A nice, bushy shrub 3 to 4 feet high, with narrow leaves, dark green above and lighter underneath, and bearing attractive black berries in autumn.

KALMIA LATIFOLIA. Mountain Laurel-Many consider this our finest native plant. It has beautiful glossy green leaves fully covering the plant and bears great clusters of rose-colored flowers in June. Is often used to mix with Rhododendron plantings; is fine for massing and beautiful enough to stand as a single specimen anywhere. 
IV Y, ENGLISH. Hedera helix-Erergreen vines that cling to rock or stone. The foliage is dark, rich and thick. The vines live to great age and suggest the romance of old castles and ivied towers.

LEUCOTHOE CATESBAEI. Andromeda-Long, exotic looking leaves of fine green; grows especially well in shade. Small white flowers in drooping racemes in spring; but the value lies in the foliage and in the plant's adaptability to shady places.

LEUCOTHOE CALYCULATA-A very pretty native plant of spreading growth with small, bell-shaped blooms in early spring.

MAGNOLIA GRANDIFLORA-The largest and most majestic of our native evergreen trees; the leares are of immense size and the flowers are large in proportion: pure waxy white, and of most delicious fragrance. Blooms very young. All our plants are nursery grown, with fine root-systems and handled with expert care.

MAHONIA AQUIFOLIA-Holly-Leared. A native plant with purple, prickly leaves and showy, bright yellow flowers.

MAHONIA JAPONICA-Broader leares than the former, and they hold their color, while those of the Aquifolia turn bronze.
LONICERA PILEATA-A bush honeysuckle of dwarf habit, with glossy green leaves all the year; small white fragrant blossoms and attractive purple berries.

PACHYSANDRA TERMINALIS-An evergreen vine that spreads rapidly and covers the ground like a carpet. It will grow in dense shade. There is no other plant so valuable for covering the ground under trees and shrub plantings. The foliage is rich and evergreen.

RHODODENDRON, CATAWBIENSE-A native variety perfectly hardy, with glossy foliage and fine clusters of rosy-lavender flowers in spring.

RHODODENDRON, MAXIMUM-Another hardv native variety with fine leaves; blooms in early spring; the buds are pink and the flowers are white when open. Fine for planting in woodlands, for naturalistic effect, or for grouping.

RHODODENDRONS. HYBRIDS-We can supply these in assortment. Since the exclusion of European stockthe former source of the supply of very nearly all the Hybrid Rhododendrons planted in this country-these wonderfully beautiful plant :have been very scarce. That handicap is being rapidly overcome now by the propagation of Rhododendrons here at home. They are the aristocrats of the garden. Rhododendrons will not succeed in soils where lime is appreciably present. We can supply a limited number of the best Hybrids in different colors.

\section{The uninviting back-yard can be made a beautiful and enjoyable outdoor living-room for summer days}

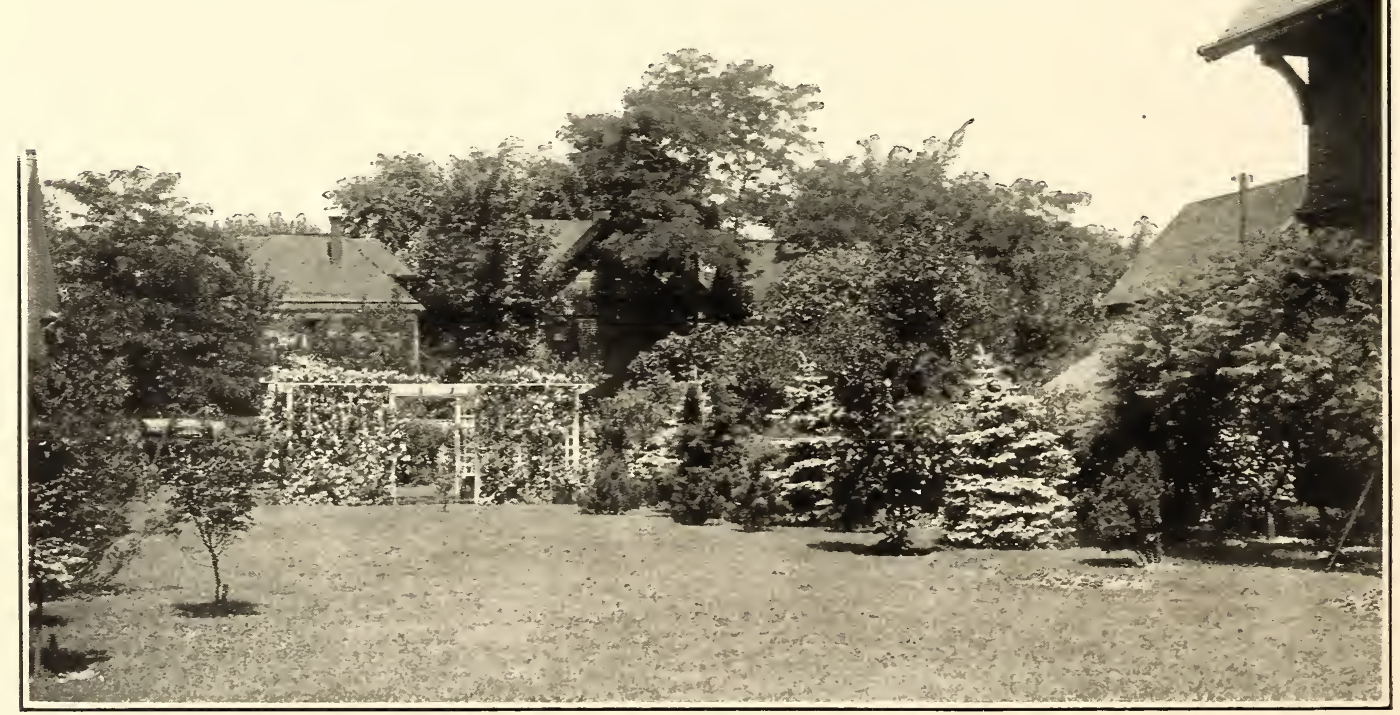




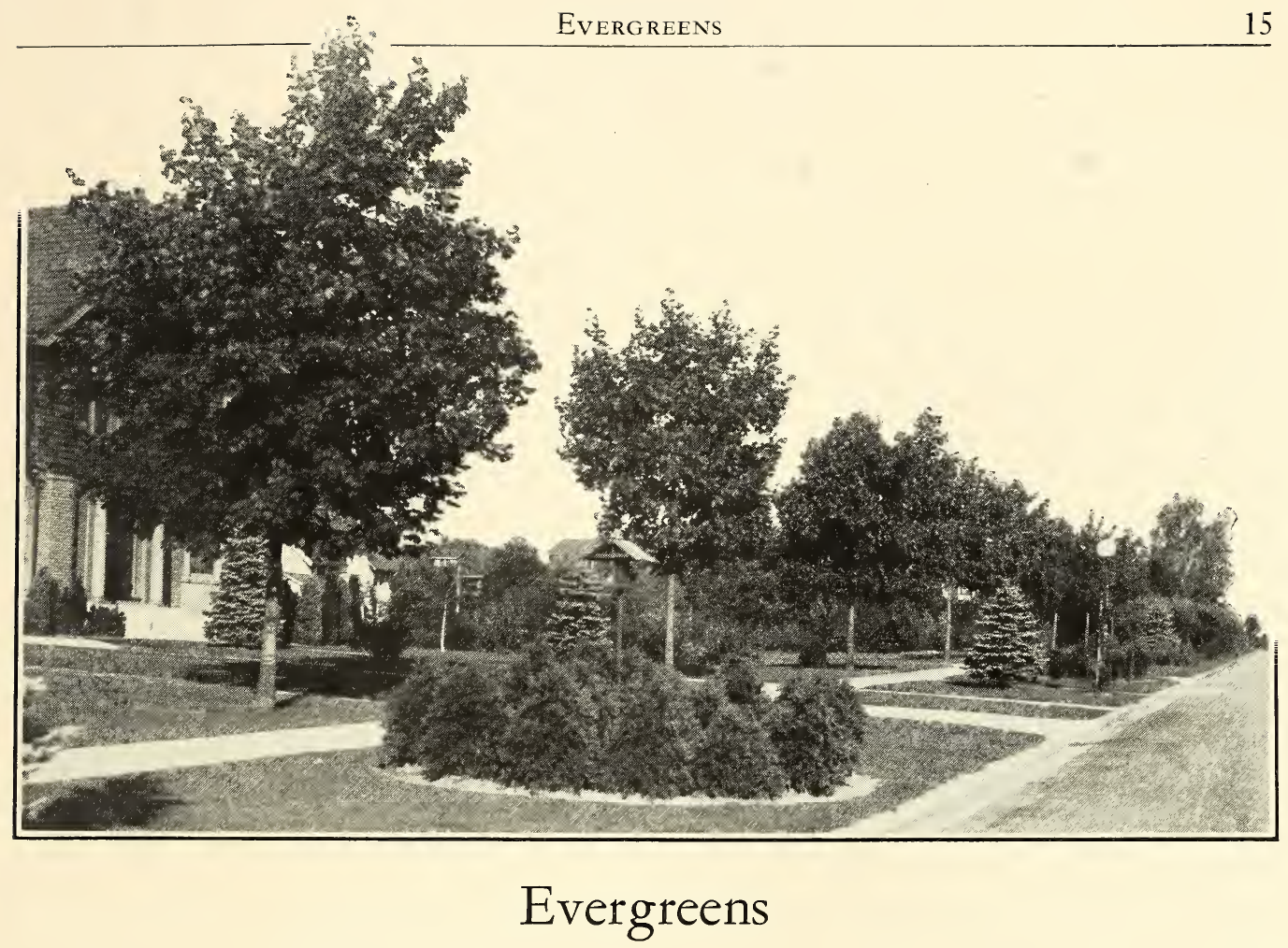

Conifers, or Narrow-leaved, Cone-bearing Evergreens

$\mathrm{TN}^{\mathrm{N}}$ this class of plants and trees, there is great range of size and shape: from tall and stately trees, to prostrate forms that hug the ground. And that makes it possible to select Evergreens for any purpose and every situation. Spruces and Pines make fine windbreaks; Arborvitae and Hemlock are ideal for hedging; the Yews and Junipers combine handsomely with the more erect Conifers in foundation plantings.

Evergreens are beautiful throughout the whole year. In summer, their fresh green makes the garden look cool and inviting; and in winter, they add a sense of warmth and life to the landscape.

Here, we are so ideally situated that we can grow, with equal perfection, the hardy Spruce, Firs and Hemlock of the North as well as the less hardy Retinosporas, the Oriental Arborvitae and the beautiful Cedrus Deodora of the South.

Conifers can be planted with reasonable safety at almost any time except winter, provided the ground is damp and warm. We are giving especial attention to the propagation of Evergreens for our section and our list includes a fine assortment. We indicate the general habit of each: L., Large-growing; M., Medium; D., Dwarf.

ARBOR VITAE, AMERICAN. M. Thuya OccidentalisA well-known native variety of upright, conical, growth and medium size, especially valuable for screens and hedges.

ARBORVITAE, AUREA NANA. D. Dwarf Golden Arborvitae-A perfect gem; the most decided dwarf, compact, regular form; ideal for small gardens. For window and porch-boxes, a favorite substitute where it is too cold for Palms and other decorative plants.

ARBOR VITAE, CHINESE. D. Biota Orientalis-A small tree with erect branches and dense, flat, light green foliage.

ARBOR VITAE, CHINESE GOLDEN. D. Biota, orientalis aurea-The most elegant and charming and therefore the most popular of the Arborvitae. The beautiful golden tint of the foliage and the compact and regular outline of its form, make it unusually attractive.

ARBOR VITAE, GLOBE-HEADED. D. Thuya Globosa -Forms a dense, round head; dwarfish in habit, hardy and desirable. 
ARBORVITAE, CONICA DENSA-A dense, low-growing form of American Arborvitae, dwarf and conical; makes a good small hedge or border; holds its green color through the winter.

ARBOR VITAE, DOUGLAS'S GOLDEN. T. occidentalis douglasi. D.-Hardy, with fine, golden foliage.

ARBORVITAE, ELEGANTISSIMA. Thuya. D.-The branches are handsomely tipped with golden yellow.

ARBOR VITAE, ELLWANGERIANA. D.-Low, spreading growth, with slender branches and thread-like foliage; extremely graceful and ornamental.

ARBORVITAE, EVER GOLDEN. D. Biota orientalis semperaurea. $\mathrm{D}$. This very distinct variety is most desirable on account of never changing its bright golden color.

ARBORVITAE, HEATH-LEAVED. Thuya ericoides. D.-Makes a dense bush only a few feet high, with distinct, heath-like foliage; very attractive.

ARBORVITAE, HOVEY'S GOLDEN. T. occidentalis hoveyi. D.-Of dwarfish habit, globular, with light yellowish green foliage; hardy and fine.

ARBORVITAE, LUTEA. M.-Peabody's Golden. Pyramidal, with gold-tipped foliage; hardy and desirable for small places or cemetery lots.

ARBOR VITAE, NOOTKA SOUND. M. Thuya Plicata. - Similar to Siberian, growth shorter and branches so disposed as to give them a plaited appearance.

ARBOR VITAE, PARSONS'. D. Thuya compacta.-Of compact habit and yellowish green foliage; its small size makes it desirable for use in small places.

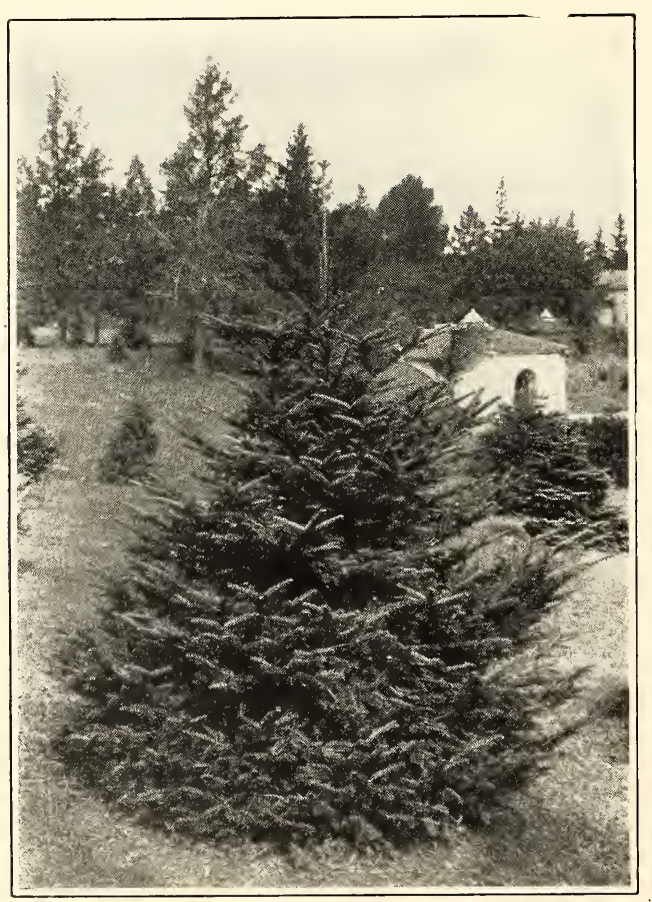

Balsam Fir
ARBORVITAE, PUMILA. D. - A very pronounced dwarf, nice and compact, with dark green foliage.

ARBORVITAE, ROSEDALE. D.-Feathery foliage like the Retinosporas, but compact and dense like the Arbor Vitae; distinct steel blue color.

ARBORVITAE, SIBERIAN. D.-Of medium size, with dark green foliage and compact growth; very hardy.

ARBORVITAE, TOM THUMB. D. - Very small and round; low, compact, growth; good in any ornamental planting, especially small gardens and cemetery lots.

ARBORVITAE, UPRIGHT. M. Thuya Pyramidalis.Of very erect habit, tall and column-like; dark green, compact and desirable; hardy.

CEDAR, DEODAR. L. Cedrus Deodora.-Tall, with wide-reaching, drooping branches and fine, feathery bluish-green foliage; not entirely hardy north of Philadelphia; the most beautiful evergreen for the South.

CYPRESS, CHAMAECYPARIS THYOIDES-White Cedar. Makes a tree from 70 to 80 feet high, with erect, spreading branches, irregularly arranged; very thin and slender, with glaucus or light green foliage.

CYPRESS, LAWSON. M. Cupressus Lawsoniana.A large, graceful tree with elegant, drooping branches; dark, glossy green foliage; one of the finest of its class.

FIR, BALSAM. Abies balsamea. L.-Tall, erect, pyramidal, with dark green foliage. Very hardy.

FIR, CONCOLOR. L.-White Fir. Tall and graceful, with handsome leaves bluish above and silver undernearh; a fine lawn tree.

FIR, NORDMANN'S SILVER. L.-A noble tree, rapid in growth and regular in outline, with rich, dark green foliage, silver beneath.

JUNIPER, COMMUNIS AUREA. D.-A fine golden prostrate, or trailing variety.

JUNIPER, EXCELSA STRICTA. D.-Compact, conical shape with gray-green foliage in summer, turning steel-blue in winter.

JUNIPER, IRISH. J. hibernica. M.--Very erect and columnar with bluish green foliage.

JUNIPER, JUNIPERUS COMMUNIS. D.-A low prostrate or trailing variety, fine for edging plantings.

JUNIPER, PFITZERIANA. D.-Of low habit, broadly spreading, extremely graceful and beautiful; light green foliage; hardy and succeeds from Chicago to the Gulf. One of the finest conifers.

JUNIPER, SABINA. D.-Low, spreading, vase-like; foliage dark green; combines well with other lowgrowing plants, affording variety by its upright, yet spreading habit.

JUNIPER, SWEDISH. J. suecica-A dense growing, pillar-like, erect variety with bluish green foliage.

JUNIPER, TAMARIX-LEAVED. Tamariscifolia. D.Prostrate and trailing; fine, bluish-green foliage; good for rockeries and edging.

JUNIPER, VIRGINIANA. M.--Red Cedar. Well known, hardy, graceful and well formed; bright, rich green. 
JUNIPER, SCORPULORUM. M.-Silver Juniper. Similar to Red Cedar, but more compact, pyramidal and with very attractive silvery blue foliage that holds the same color throughout the year.

JUNIPER, VIRGINIANA CANNARTII. M.-A variety of Red Cedar that is more pyramidal in form, with dark green foliage and odd blue berries.

JUNIPER, VIRGINIANA GLAUCA. M.-A form of the native Red Cedar with fine steel-blue foliage, compact and pyramidal; one of the best of the blue evergreens.

PINE, AUSTRIAN. L.-A rapid growing tree of great size, with long, stiff, dark green needles.

PINE, RESINOSA. M.-Red Pine. Quick growing, symmetrical, with bright green foliage.

PINE, SCOTCH. P. sylvestris. L.-Of unusually rapid growth, with rugged branches and bluish foliage.

PINE, WHITE. P. strobus. L.-Very hardy; the handsomest of the pines, with abundant silvery-green foliage; grows quickly and in the poorest soils.

RETINOSPORA FILIFERA. M.-Bright green, threadlike foliage and of weeping habit.

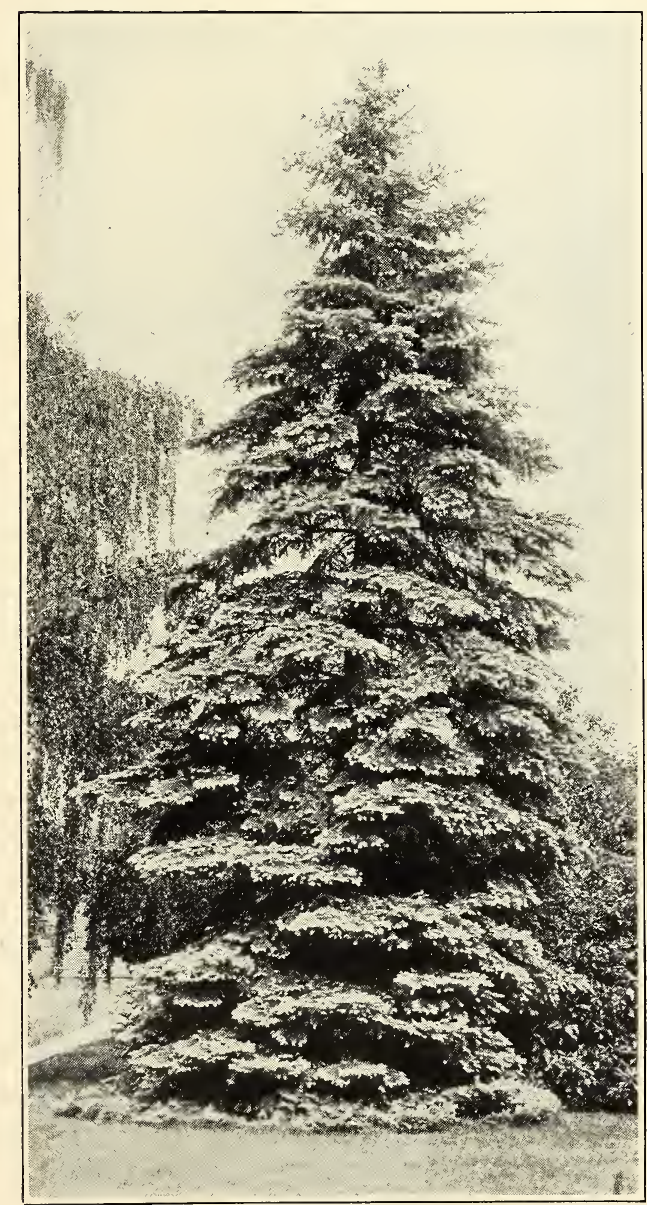

Norway Spruce

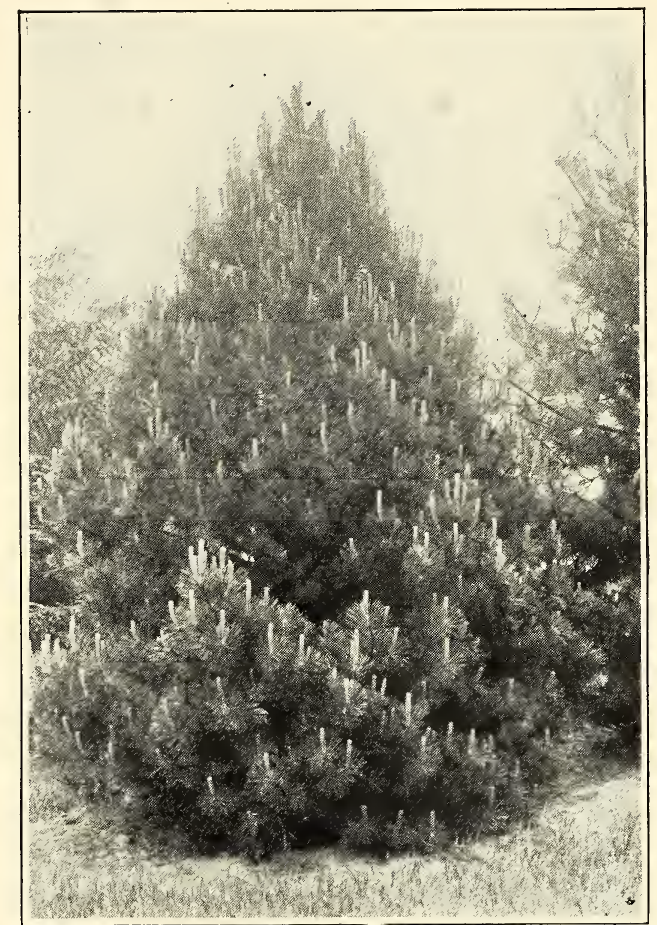

Austrian Pine

RETINOSPORA FILIFERA AUREA. M.-A golden branched form of above.

RETINOSPORA OBTUSA. M.--Distinct, with bright green fern-like branches, that droop gracefully.

RETINOSPORA PISIFERA. M.-Has bright green, pendulous branches.

RETINOSPORA PISIFERA AUREA. M.-Like Pisifera, but with rich, golden yellow foliage.

RETINOSPORA PLUMOSA. M.-A very compactgrowing variety with small, light green leaves and short, slender branches.

RETINOSPORA PLUMOSA AUREA. M.-A distinct and striking variation of the Plumosa and valuable in this section; the tips of the branches have a beautiful golden yellow hue.

RETINOSPORA PLUMOSA ARGENTEA. M.-Another variation, in which the young shoots are tipped and sprinkled with silver.

RETINOSPORA SQUARROSA VEITCHII. M.-Soft and feathery foliage in round, compact form; beautiful silvery grey.

RETINOSPORA SQUARROSA SULPHUREA. M.Like the former except that in spring and early summer, it has a distinct yellowish cast.

SPRUCE, BLACK HILLS. Picea canadensis albertiana. L.-A type of White Spruce, of great hardiness, resistance to drouth and admirable for the lawn, or sheltering windbreaks. Rich, dark green foliage. 


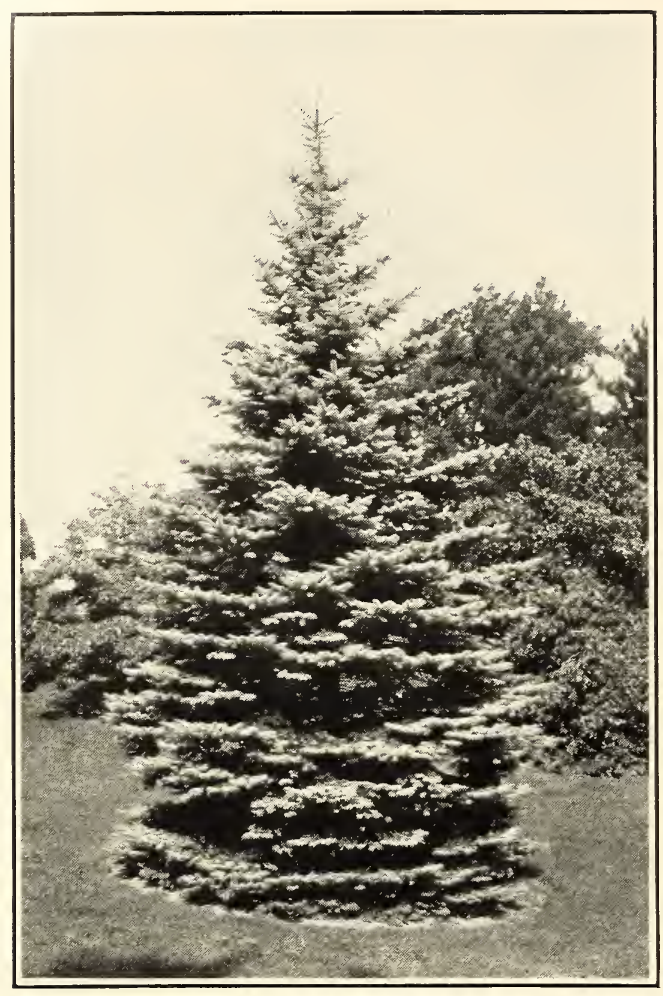

Colorado Blue Spruce

SPRUCE, COLORADO BLUE. A. pungeus. M.-A rare and beautiful tree with rich blue foliage; shapely, graceful and striking; the blue color is in spring and summer only and does not last during winter, when it turns bluish green.

SPRUCE, DOUGLAS. Abies douglasi. M.- Shapely, with spreading branches; leaves light green above, silver beneath; rapid-growing and valuable, but the foliage browns badly in some localities.

SPRUCE, KOSTER'S. A. pungens kosteri. M.-A distinct variety of above, which holds its blue color throughout the year. Very rare and scarce.

SPRUCE, HEMLOCK. A. canadensis. L.-One of the most beautiful of all conifers. Perfectly hardy, graceful with long, drooping branches and rich green foliage. Makes a beautiful ornament on the lawn or can be planted in hedge-form and sheared to perfect lines. For an all-around evergreen, there is nothing better.

When planting Evergreens, selection should be carefully planned and with definite purpose in mind. Is it to be a foundation planting along the side of the house and about the porch? Then the Arbor Vitae, Retinosporas and Yews, edged off with dwarf and trailing Junipers, are the plants. Pines and Spruces are out of place there. In any group planting, the relative height of varieties at maturity, should be remembered. In planting single specimens, the ultimate spread is important.
SPRUCE, NORWAY. Abies excelsa. L.-Of rapid and lofty growth. After reaching 15 or 20 feet, the long branches become decidedly drooping and touch the ground, making a beautiful tree on the lawn. Or it can be planted for screening or for a shelter against wind. Has very dark, rich green foliage.

SPRUCE, ORIENTALIS. M.-Erect and pyramidal, with short, closely set dark green, shiny needles.

SPRUCE, WHITE. A. alba. L.-A very pretty tree that attains a height of 40 to 50 feet, compact and conical, with soft, light green foliage; hardy and desirable.

YEW, or TAXUS. M. T. BACATA.--English Yew. A small, bushy tree with dark green, glossy foliage; suitable for clipping into formal shapes.

YEW, BREVIFOLIA. D.-Very low and spreading, with rich dark green short foliage; very hardy and desirable for rockeries or edging evergreen plantings.

YEW, CANADENSIS. D.-Low-growing, but bushy and spreading with short pale green leaves that take on a reddish tint in autumn.

YEW, CUSPIDATA. D.-Very desirable and valuable on account of its entire hardiness in severe northern winters; upright, with good foliage and recommended as the most dependable of the Yews.

YEW, IRISH. T. FASTIGIATA. M.-Of close, erect habit and dark green foliage.

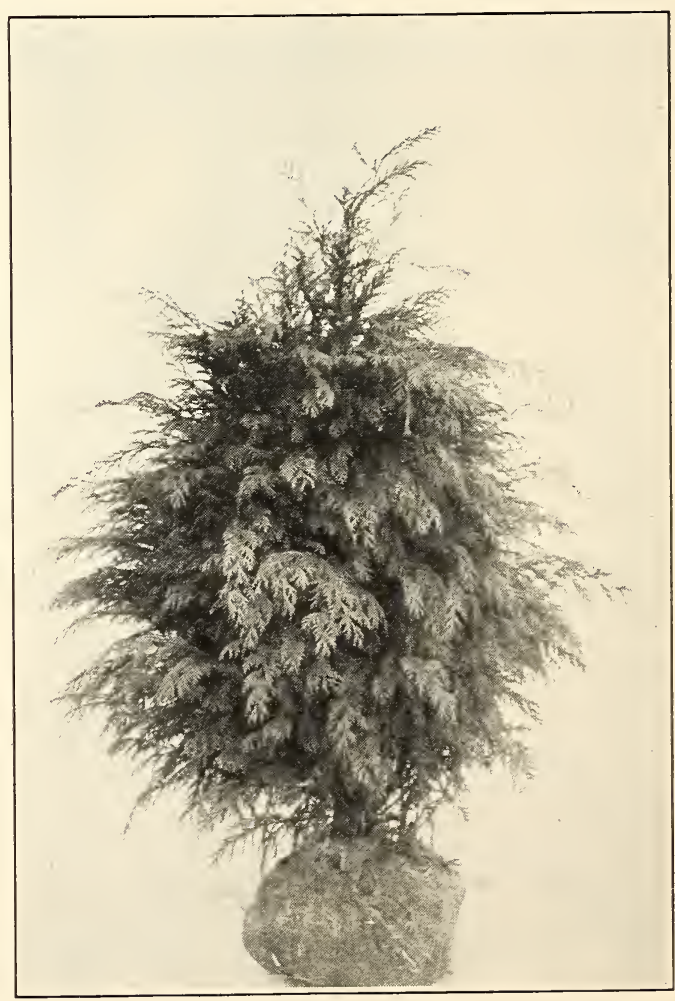

Retinospora Pisifera 


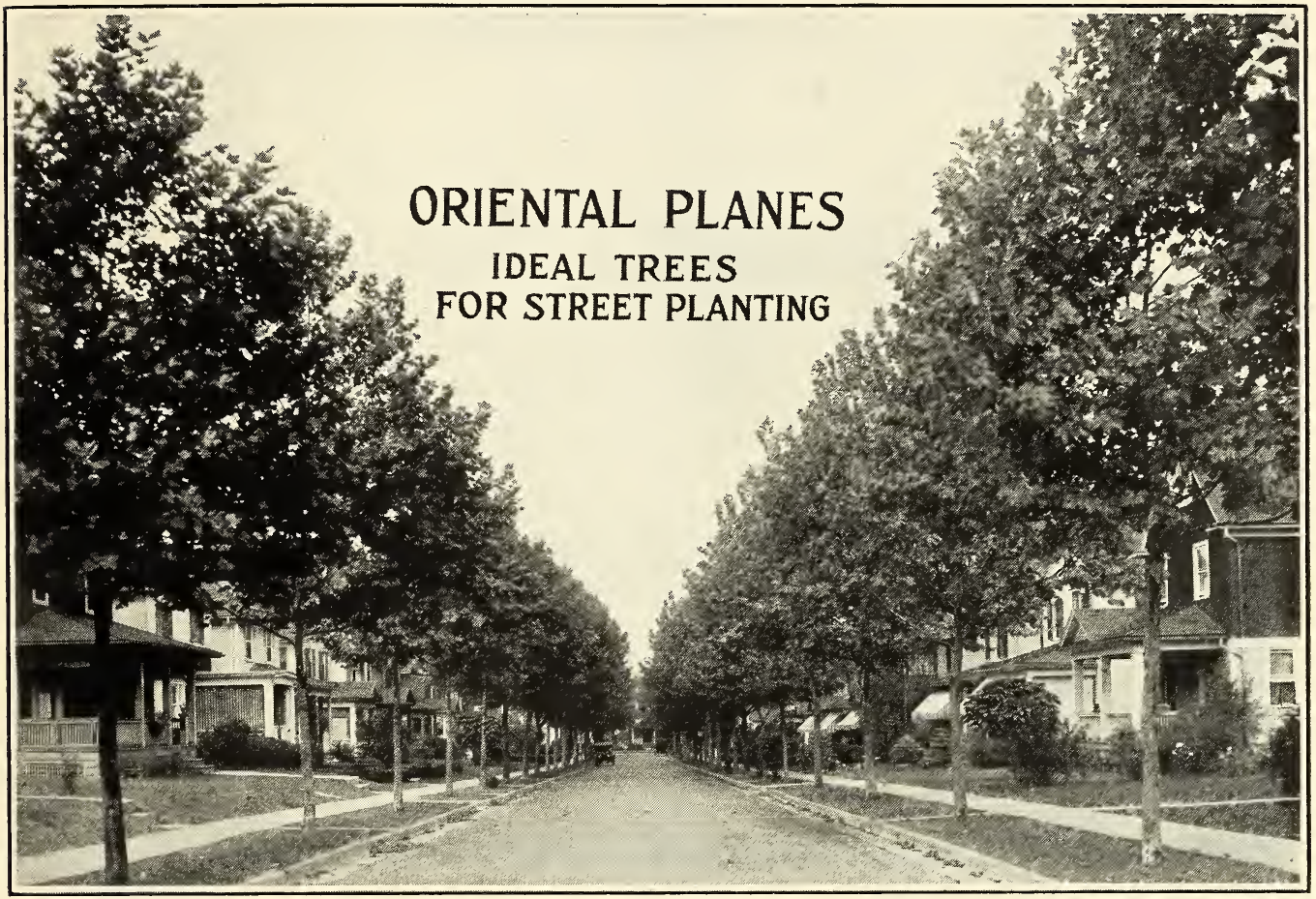

\section{Shade, Ornamental and Flowering Trees}

THEY serve many purposes - and therefore should be selected and planted with careful thought of the purpose to be served and the situation and surroundings in which they are to be placed. In that respect, our Landscape Service Department can help with suggestions.

We indicate generally the proper situation for each variety and its chief point of beauty or usefulness: $\quad \mathrm{S}-$ Suitable for Street planting;

$\mathrm{L}-$ Best on the Lawn, as a specimen tree;

F - Has especially attractive or colored foliage;

B - Blooms conspicuously or has colored berries.

AMELANCHIER CANADENSIS. B.--Of erect and narrow growth, one of the finest early-flowering trees, the white flowers, produced in April, being followed by small, purplish fruits.

ASH, AMERICAN WHITE. Fraxinus Americana-A native tree of large size, wich pale green leaves. The best Ash.

ASH, MOUNTAIN. European. Sorbus aucuparia. B.-A small tree with dense and regular head; in the North, covered from July till winter with great clusters of brighi scarlet berries, but here and southward, it drops them earlier.

BOXELDER. Acer negundo. Ash-leaved Maple. L.Very rapid growing, makes a round, neat head and has noticeably light-green leaves.

BEECH AMERICAN. Fagus ferruginea. L.-A tall and pyramidal tree, branching from the ground up, beautiful as a lawn specimen.
BEECH, PURPLE-LEAVED. F. sylvatica purpurea. L. F. - The Copper Beech is similar in growth but the leaves, reddish at first, take on a rich copper tint in summer. The Beeches do better farther North; our hot summers are trying to them.

BIRCH, WHITE. Betula alba. L.- Erect and inclined to make two or three main trunks from the ground; at maturity, these bend outward and downward in a graceful fashion. The great charm is the silvery white bark, especially attractive in winter; effective along streams.

BIRCH CANOE. B. papyracea. L.-Erect and tall-growing, with large leaves and conspicuous white bark. Easily grown.

CATALPA SPECIOSA. S. B.-A very tall-growing tree of irregular habit. Immense leaves of dark green and in July has attractive white flowers in large panicles. Hardy and long-lived. 


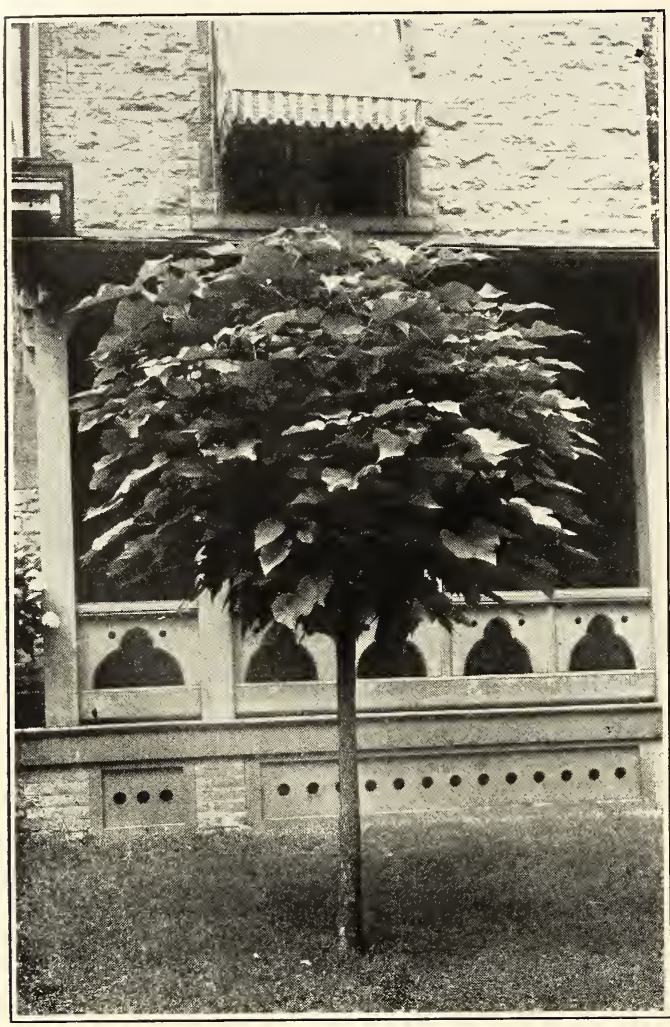

Catalpa Bungeii

CATALPA BUNGEII. L.-Very formal small trees, with small, round heads grafted on stems at about 5 feet; they do not grow taller. Planted in pairs or in rows they are an attractive part of any formal design.

FLOWERING CRAB APPLES. Malus or Pyrus. B.-A valuable group of small trees, all having conspicuous flowers, in the case of some varieties, followed by small, bright-colored apples more ornamental than edible.

FLOWERING CRAB APPLE, ATROSANGUINEA. L. -Bears great quantities of single, rosy-red flowers, followed by ornamental little apples.

FLOWERING CRAB APPLE, BECHTEL'S. L.-One of the very best and the best known; has large, double flowers like a miniature rose, of the most beautiful pink, literally covering the tree in spring; makes a very neat, compact tree and as wonderfully beautiful a specimen as can be placed on the lawn.

FLOWERING CRAB APPLE, FLORIBUNDA. L.-As the name indicates, is very floriferous, producing masses of flowers that are red in bud, light pink when open and of delicious fragrance; rather strong growing, making a tree rather larger than most Flowering Crabs.

FLOWERING CRAB APPLE, ATROPURPUREA. L.Like the last named, but with buds and open flowers of a deeper color.
FLOWERING CRAB APPLE, PARKMANII. L.--Loosegrowing rather than compacr, with semi-double rosypink flowers. Very attractive.

FLOWERING CRAB APPLE, SCHEIDECKERII. L.Small, shapely and compact tree with double, rosypink flowers that are very lasting.

FLOWERING CHERRIES. Cerasus. L. B.-These are extremely ornamental trees that bloom in early spring. The flowers are single and double, white and pink. We can offer a limited number or trees, including both Standard and Weeping varieties. Very scarce and rare and in demand wherever their great beauty is known.

CORNUS FLORIDA. L. B.-Our native White-flowering Dogwood, whose dainty single white blossoms appear in early spring before the leaves are out.

CORNUS FLORIDA RUBRA. L. B.-A red-flowering variety of the former; similar in every way except that the flowers are rosy-pink to red; a fine companion tree for the white-flowered variety.

ELM, AMERICAN. Ulmus Americana. L. or S.-The most beautiful of all our native shade trees; growing to great size and long-lived, sturdy, yet supremely graceful, its towering head spreads and the wide branches droop beautifully. Fine as a street tree, the tops often meeting and completely shading the street. Grows everywhere.

FRINGE TREE. Chionanthus virginica. White Fringe. L. B.-A native small tree with ash-like leaves and drooping racemes of white flowers, resembling an elegant fringe.

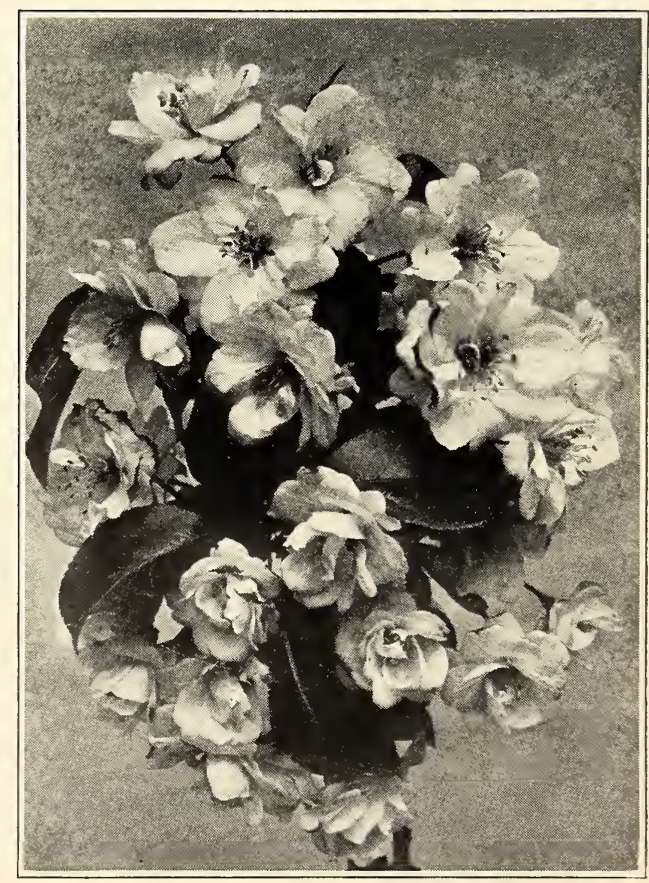

Bechtel's Double-flowering Crabapple 
HAWTHORN, CRATAEGUS OXYCANTHA.-The single white Hawthorn of English hedges, but not so valuable here, for the purpose.

HAWTHORN, DOUBLE WHITE. L. B.-Makes a small tree, widely branching, with attractive small, very double flowers.

HAWTHORN, DOUBLE PINK. L. B.--Similar, but with double pink flowers.

HAWTHORN, DOUBLE RED. L. B.--Bright red, very double flowers.

HAWTHORN, COCCINEA. L. B.-Small and shrubby, with single white flowers followed by scarlet fruits.

HERCULES CLUB. Aralia spinosa. L.-A small sized tree, inclined to sucker and form a clump, with rough, prickly stems bearing large panicles of white flowers in midsummer; good for massing or screen planting.

HORSE CHESTNUT. Aesculus hippocastanum. S. B.White-flowering. A tall-growing tree of regular outline, pyramidal, with attractive white flowers; does best in the North; here, the hot sun burns the leaves.

HORSE CHESTNUT. AE. rubicunda. Red-flowering. L. B.-Fine in foliage and flower; darker green in leaf than the white-flowered variety; does better here.

JUDAS TREE. Cercis canadensis. Red Bud. L. B.-A fair-sized tree, branching from the ground and growing irregularly yet gracefully, with every branch covered in early spring before the leaves appear, with small delicate pink flowers.

JUDAS TREE. C-japonica. Japanese. L. B.-The flowers are larger than those of our native Red Bud, of a light rose color and in the same profusion. Encirely hardy and very beautiful.

LARCH, EUROPEAN. Larix europaeus. L.-A beautiful and rapid-growing tree, exactly like the cone-bearing evergreens except that it drops its foliage in winter. Desirable in every way except that it is not evergreen.

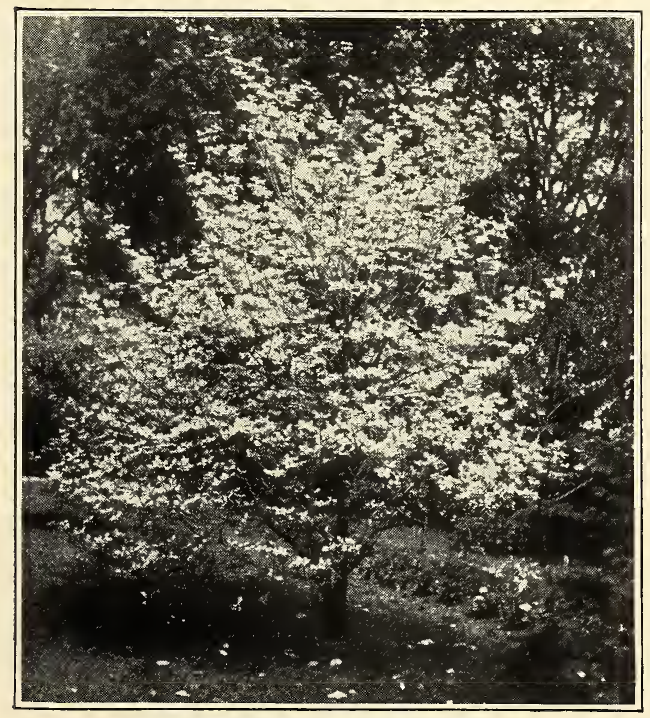

Canus Florida - Flowering Dogwood

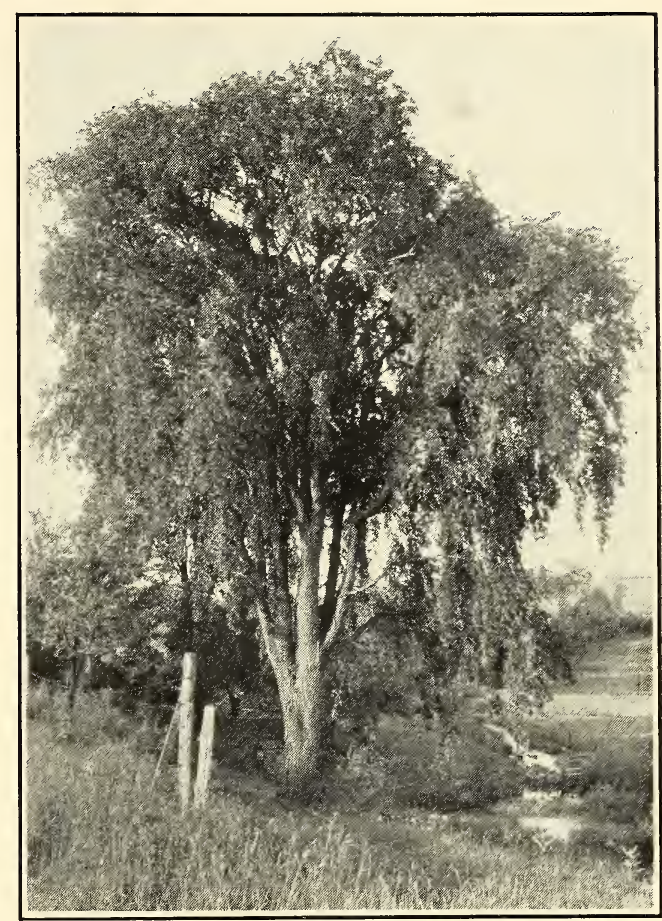

American Elm

LINDEN. American Basswood. Tilia americana. S.A large, fast-growing tree of erect growth, with compact, rounded head, large leaves and fragrant flowers. Makes a fine tree for street or avenue planting; rather formal and precise in outline.

LINDEN, EUROPEAN. T. europaea. S.-A fine pyramidal tree, very much like our own Basswood, but does not grow so tall.

LOCUST YELLOW. Robinia pseudacacia. B.-A valuable native tree of rapid growth and large size, with soft and graceful foliage of refreshing light green; bears quantities of white or yellowish flowers of great sweetness, in drooping racemes like a wisteria.

MAIDEN HAIR TREE. Salisburia adiantifolia. Gingko. S.-Small leaves like Maidenhair fern. Makes a beautiful avenue tree, tall, graceful and imposing.

MAPLE, NORWAY. Acer platanoides. S.-One of the most beautiful street trees; tall, compact, rounded, with broad, deep green leaves, hardy and long-lived, it is one of the most popular of all shade trees.

MAPLE, SCHWEDLER'S. A. platanoides schwedler. S. F.-Similar to the Norway Maple, but has purplish crimson leaves in spring, changing to bronze on maturing. Very hardy and desirable for ornament or shade.

MAPLE, SUGAR. A. saccharinum. S.-A well-known native tree of stately growth, fine form and foliage, desirable for lawn or street planting. It is also the source of our Maple sugar and syrup. 
MAPLE, SCARLET OR RED. A. rubrum. S. F.-A native tree of moderate size, producing very small, red blossoms, and in autumn, the leaves change to a brilliant scarlet.

MAPLE, SILVER-LEAVED. A. dasycarpum. S.-The quickest-growing of the Maples; not so compact as the Norway type-rather spreading and looser-with fine bright green leaves, silver underneath. Fine for street, park, or lawn planting; produces shade quickly and is very popular and widely planted in the South.

MAPLE, WIER'S CUT-LEAVED. A. dasycarpum wieri laciniata. L.-For ornament rather than shade; like the Silver Maple, but with deeply dissected leaves and of decidedly weeping habit, with side branches touching the ground. A very beautiful lawn tree.

MAPLE, JAPANESE. A. palmatum (polymorphum). L. F.-These are of a distinct and different type, hardly of tree dimensions-shrubs, rather; the foliage is the great charm, the leaves being colored in the different varieties, from light green to dark purple, some finely and deeply dissected; and the foliage of all is dense and handsome. Planted singly, they are always conspicuous; in groups, they blend attractively.

MAGNOLIAS, ACUMINATA. Cucumber Tree. L. B.A very quick growing tree of great ultimate height, with attractive greenish yellow flowers. A native of hardiness and great value.

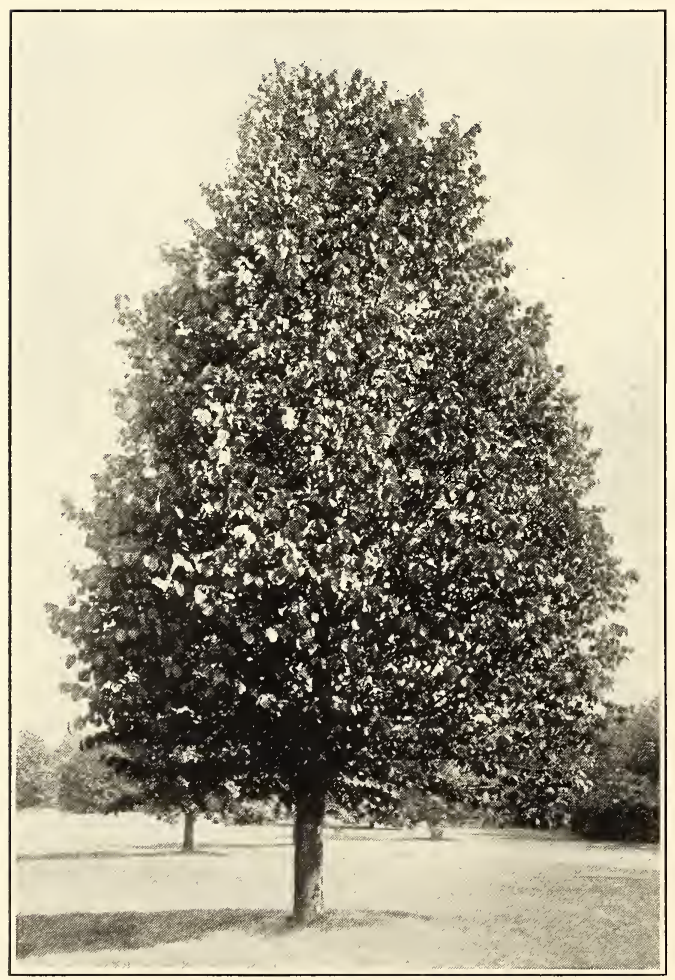

Linden

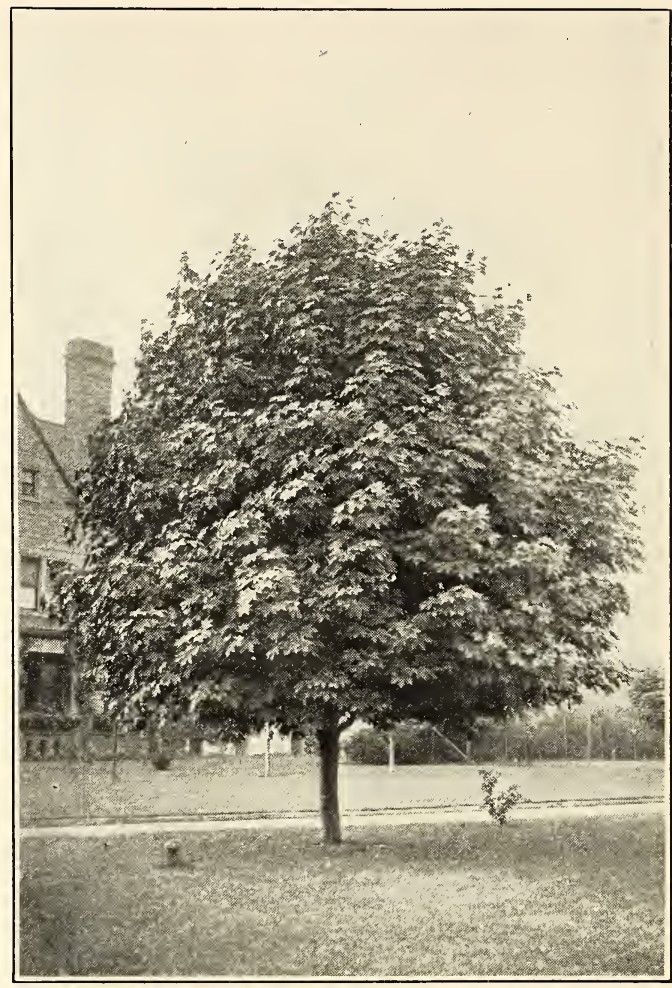

Norway Maple

MAGNOLIAS. L. B.-These are all admirably adapted to the South, though many of the deciduous varieties are very hardy and succeed in the colder parts of the North. In the case of all of them, the leaves are large and rich green, the blooms of all are most fragrant, of great delicacy and among the most beautiful of flowers.

MAGNOLIAS, GRANDIFLORA-See page I4.

MAGNOLIAS, PURPUREA. L. B.-Japanese Purple. A small tree, or rather large shrub, with large leaves and large, fragrant flowers, dark purple on the outside and white within.

MAGNOLIAS, SOULANGEANA. L. B.- Shrub-like and branching when young, but making in time a fairsized tree; the flowers are white and purple, 3 to 5 inches across and fragrant; blooms late; is hardy and very handsome.

MAGNOLIAS, TRIPETELA. L. B.-Umbrella Tree. Of rapid growth, making a small-sized tree with immense and tropical-looking leaves and creamy-white flowers, 4 to 6 inches across.

OAKS. Quercus. L. or S.-Are of many varieties and different characteristics. They are all very long-lived and make large trees, sturdy and imposing.

OAK, PALUSTRIS or PIN OAK. Q. palustris. L. or S. -Erect and tall-growing, rather compact with somewhat drooping branches and graceful form. A favorite tree for avenue planting. 


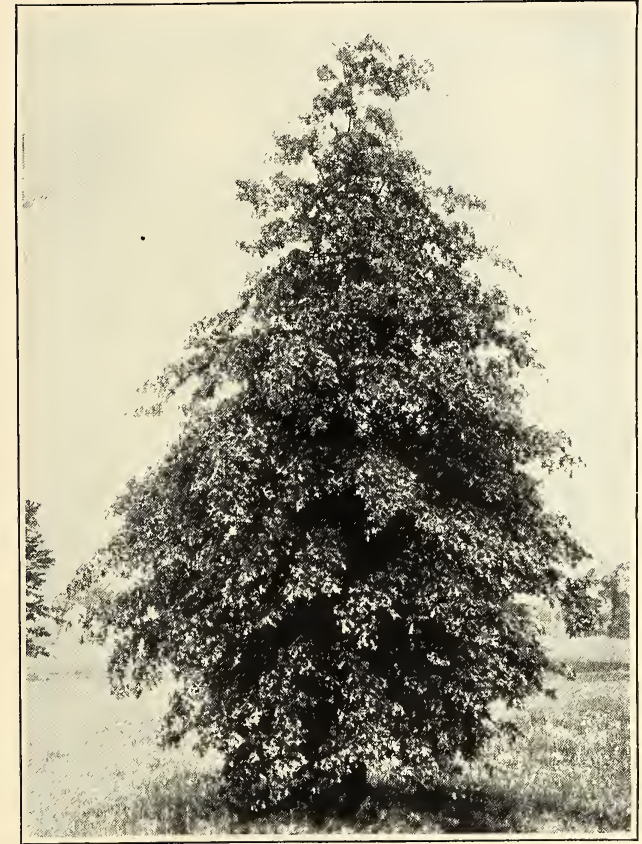

$P$ in $\mathrm{Oak}$

OAK, RED. Q. rubra. L. or S.-One of the largest of the Oaks, with a rounded, spreading head and large, bright green leaves that turn to a rich, dark red in autumn. Fine for street and avenue planting; makes a noble and stately tree on the lawn, but needs plenty of space and must stand alone; therefore, suitable only for large grounds. We recommend this as one of the most valuable of the Oaks.

OAK, SCARLET. Q. coccinea.-Makes a large tree of 5o to 60 feet, well-shaped, with fine green leaves that take on the most brilliant scarlet color in autumn. One of the most popular of the Oaks, for street and avenue planting or for large grounds.

OAK, WHITE. Q. alba. L. or S.-A native variety of noble proportions and widely-spreading branches; rugged in appearance.

OAK, WILLOW. Q. phellos. L.-Of good size and attractive appearance; very distinct in foliage, the leaves being small, narrow and willow-like; does best in moist situations.

ORIENTAL PLANE. Platanus orientalis. S.-Popular for its quick growth, its fine shape, its unusually large leaves and their lasting until late in the season. Especially valuable for city street planting, because vigorous, healthy, free from disease or pests and immune to heat, dust and smoke.

PAWLONIA. P. imperialis. F.-Empress Tree. A remarkably rapid-growing tree with blue, fragrant, trumpetshaped flowers; but the striking feature is the immense, tropical-looking leaves, like erect elephants' ears.

PEACH, DOUBLE FLOWERING WHITE. Persica vulgaris alba flore pleno. B.-The growth is that of ordinary peach trees, smaller, though, with very double, pure white flowers; non-fruiting.
PEACH, DOUBLE FLOWERING RED.-Similar, with fine, bright red flowers.

PEACH, DOUBLE PINK-With double, pale rosecolored blooms.

POPLAR CAROLINA. Populus monilifera. S.-The best to plant where quick shade is wanted: the fastestgrowing of all. Tall, branching, with good leaves. Sometimes planted as a "filler" between slower-growing, more permanent shade trees and then removed when the latter have grown up.

POPLAR, LOMBARDY. P. fastigiata. L.-Grows straight up and makes little width: tall and shaft-like, reaching, at maturity, a height of 80 to too feet. Is impressive where it fits into the picture: along avenues or water courses, as a very tall screen or background to accentuate the proportions of other, lower-growing trees.

TULIP TREE. Liriodendron tulipifera. L. B.-A beautiful native tree ot pyramidal form and large size, large, smooth, shining leaves and greenish-yellow, tulipshaped flowers. Young trees of small size transplant best.

SWEET GUM. Liquidambar styraciflua. L. F.-A Southern native tree of upright growth, making a fine, round head; has queer cork-like bark; the leaves resemble those of Maples and in autumn take on the most gorgeous red, yellow and bronze colors.

WILLOW, GOLDEN. Salix vitellina. L.-A handsome tree with golden yellow bark that is very conspicuous in winter.

WILLOW, WISCONSIN. S. blanda. L.-The largest and best of the tall weeping willows; makes a large tree with a spreading head and long, drooping branches. In any low spot, particularly near a pond or water course, is a great addition to the landscape.

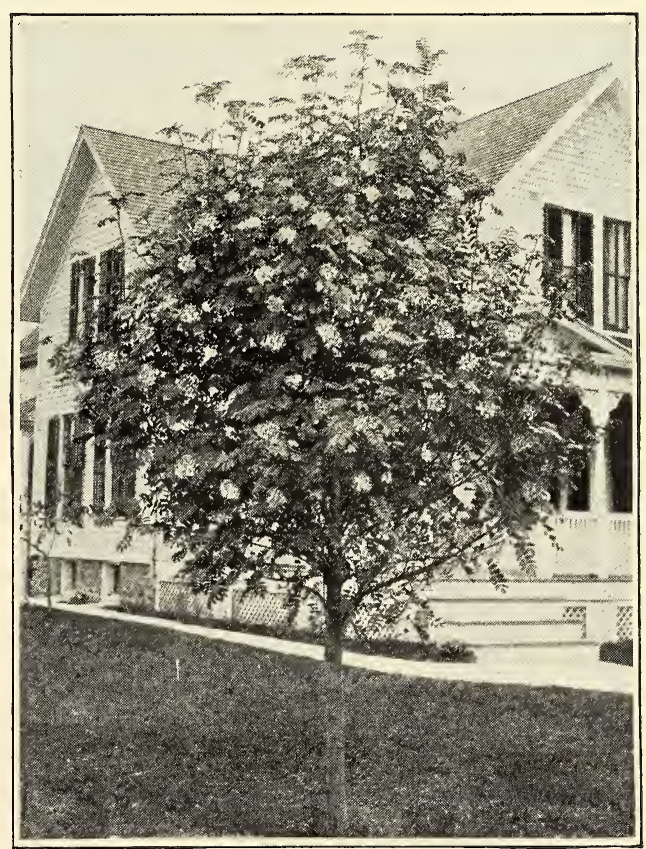

European Mountain Ash 


\section{Weeping Trees}

BIRCH, Weeping, Cut-leared. Betula alba pendula.-A charming tree in the Northern States, but does not show so much beauty South, except in very farorable locations; of very graceful, drooping habit, with silvery white bark and delicate, cut foliage. Most effective and picturesque.

CHERRY, Dwarf Weeping. Cerasus pumila pendula.-A grafted, round-headed weeping tree.

CHERRY, Japanese Weeping. Cerasus Japonica pendulaHas feathery, graceful foliage, white flowers and red fruit.

ELM, Camperdown Weeping. Ulmus Camperdown pendula.-A picturesque weeping form of Scotch Elm, grafted on stems from which it throws out branches that spread and finally touch the ground; the large, dark green, luxuriant foliage is most attractive.
ASH, Weeping. Fraxinus excelsior pendula.-A tree of medium size, with stiff, twisted, pendulous branches.

MOUNTAIN ASH, Weeping. Sorbus aucuparia pendula. - The branches of this distinct variety are of a straggling, pendant habit; a rapid grower.

MULBERRY, Teas' Weeping.-The top is grafted on a straight stem and spreading slightly, grows downward in a fine, fountain-like form, the long, slender branches touching the ground on all sides; with rich and abundant foliage and perfectly hardy, this is one of the best weeping trees.

WILLOW, Common Weeping. Salix Babylonica.-One of the most graceful and beautiful of the weeping trees; it is of rapid growth, attaining very large size and while it reaches its finest development in damp or moist soils, it grows fairly well in any good soil.

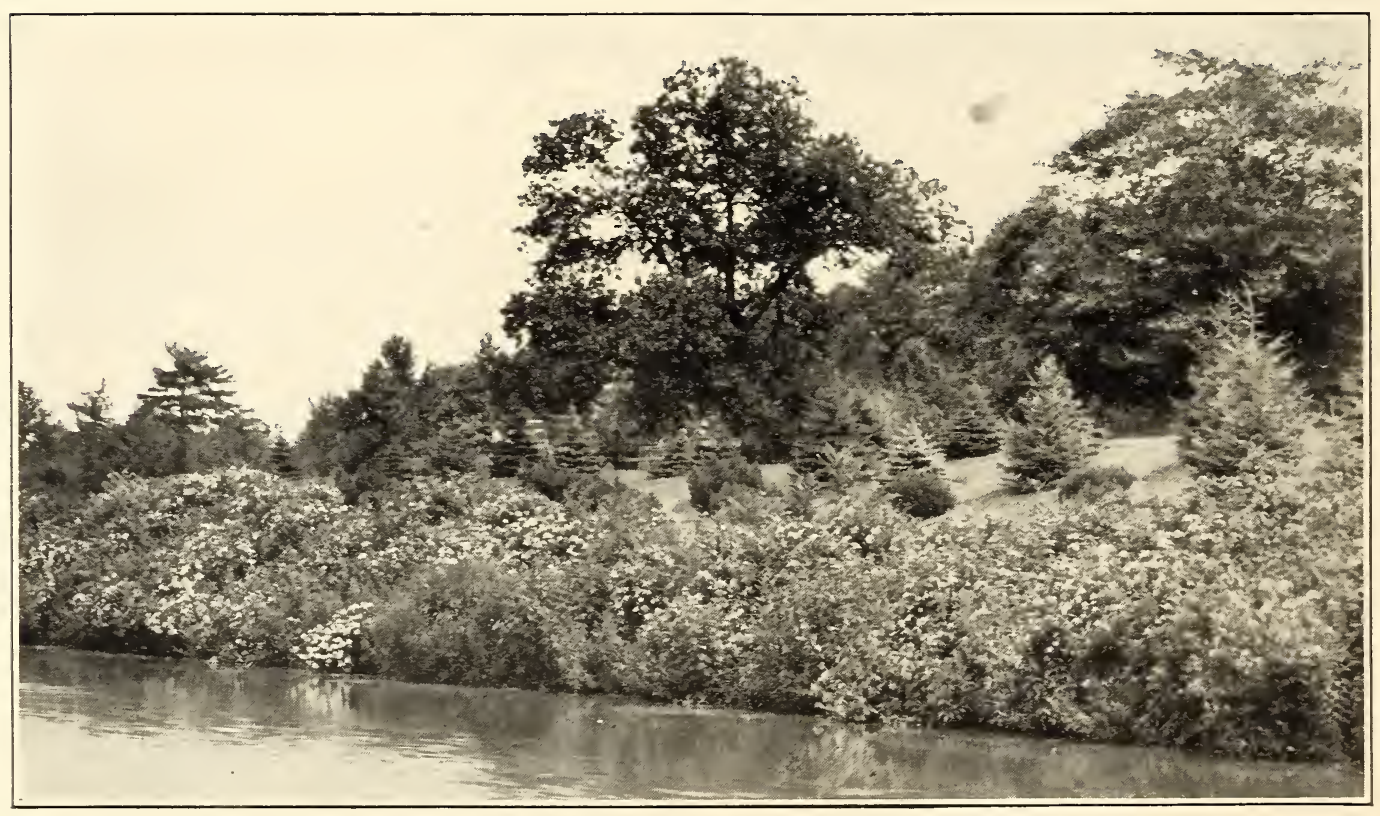




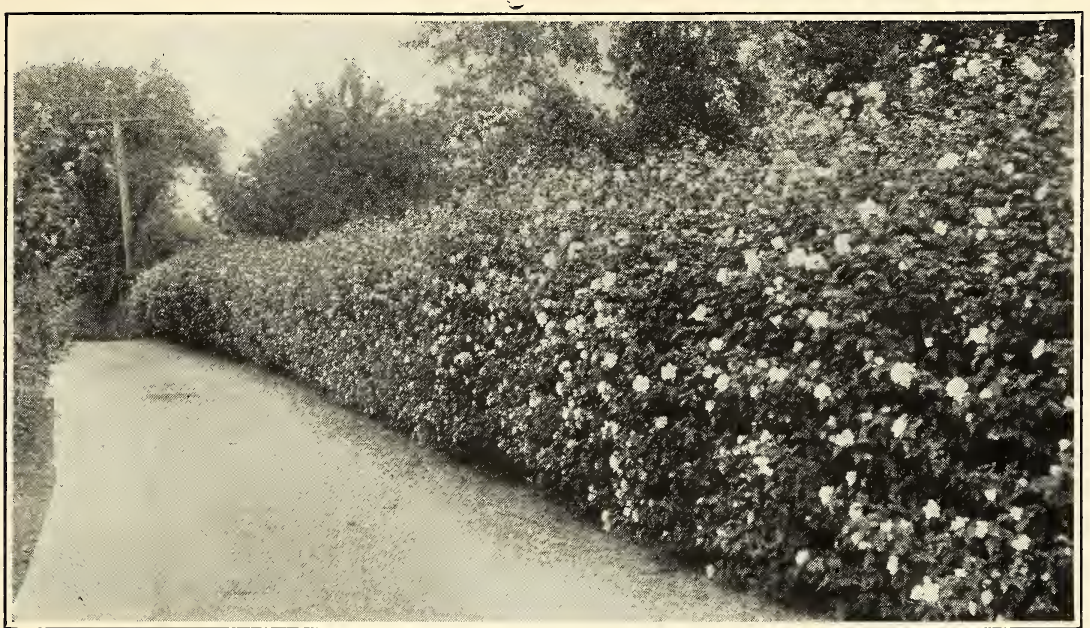

Altheas make a good bedge, especially attractive in midsummer when in bloom

\section{Hedges}

IEDGES are of various forms and serve many purposes; there is the tall screen or shelter, a use to which the Norway Spruce lends itself admirably. There is the lower hedge that serves as ornament and secures privacy as well; and American Arborvitae and Hemlock are excellent for that. And then there are the purely ornamental hedges of flowering plants like Japanese Quince, Spirea Van Houtte and Altheas. Barberry and Privet make small, formal hedges that clipping will keep in shape and hold down to any desired height.

To secure a good hedge, it is necessary to plant well. Dig a wide, deep trench and work the soil thoroughly into the roots. Settle the ground firmly, so that each plant will be set as solidly as a post, then mulch heavily with some coarse manure for a distance of a foot or two on either side, according to the size of the plants. This is especially necessary with Evergreens, and all exposure of the roots to the sun and air must be absolutely avoided.

\section{Deciduous Flowering Shrubs Suitable for Hedges}

ALTHEA-Very popular in some localities, as an ornamental hedge with large, attractive flowers in midsummer; can be pruned into any shape and is very showy either when the entire hedge is of one color or when different colors are combined. Plant 18 inches apart.

BERBERIS THUNBERGI-Beautiful, compact plants with light green leaves turning to red in autumn and with red berries in early winter; bears clipping well, makes a good formal hedge of small size or, when allowed to grow naturally, a larger hedge of graceful round habit and is unaffected by heat, dust, drought or cold. Plant 18 inches apart.

\section{The Best Evergreens for Hedging Purposes}

ARBORVITAE, American-One of the most desirable evergreen hedge-plants. Although a fast grower, it can be kept trimmed to any height desired. Best adapted for screens or windbreaks. Of very attractive appearance. Plant 18 inches apart.
PRIVET, California-An ideal hedge plant, with glossy, dark green leaves; easily held at any desired height by clipping and a smooth, even surface maintained; succeeds almost anywhere, including the seashore; almost evergreen. Plant 6 inches apart.

JAPAN QUINCE. Cydonia japonica-Bright scarlet flowers in early spring; thereafter, good foliage; grows to five or six feet. Plant 18 inches apart.

SPIREA, Van Houtte-The arching branches are literally covered with white bloom in early spring, bending and reaching the ground in a fountain-like effect; resembles a great snow bank.

SPRUCE, Hemlock-Desirable and very ornamental; can be sheared and kept compact and bushy and with an even surface. Plant 2 feet apart.

SPRUCE, Norway-Makes a tall, dense, compact hedge to take the place of a fence. Plant 2 feet apart. 


\section{Ornamental Vines and Creepers}

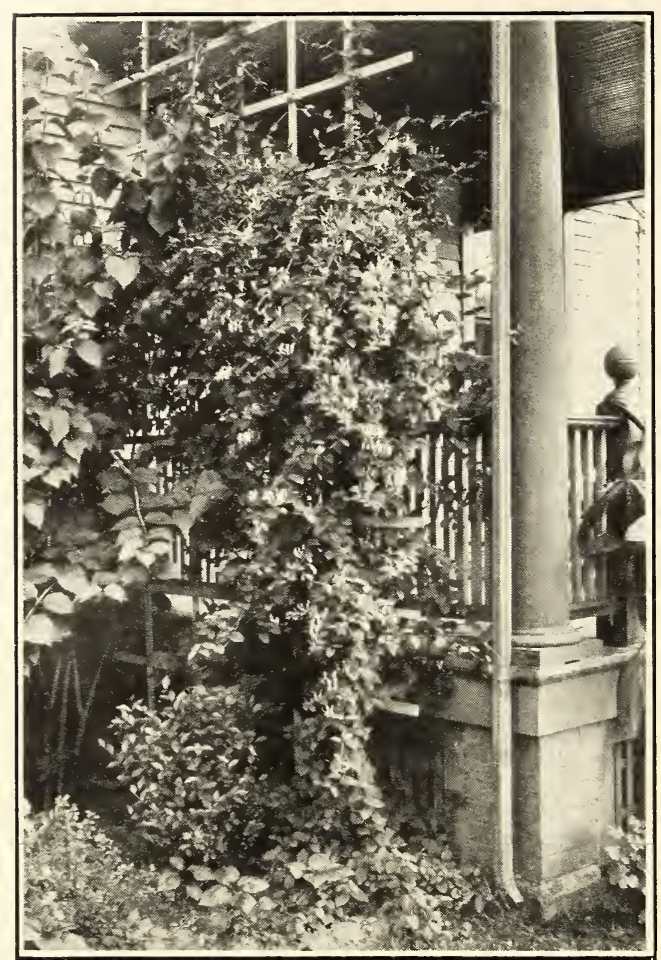

Hall's Japan Honeysuckle

AKEBIA QUINATA-Pretty, five-petaled leaves of dark green and odd purplish flowers in clusters; fragrant.

AMPELOPSIS QUINQUEFOLIA-Virginia Creeper. A native vine of vigorous growth and abundant large foliage that turns rich crimson in autumn; fine for arbors, tree-trunks or fence-covering.

AMPELOPSIS VEITCHII-Boston Ivy. Large, threepetaled leaves of dark green, taking on beautiful autumnal tints. The great value of this vine is that it is hardy, self-supporting and clings to brick and stone, forming a thick mat on the wall.

ARISTOLOCHIA SIPHO-Dutchman's Pipe. The leaves are very large and overlap; a fine screen for porches.

CLEMATIS-Favorite vines for trellises, pillars and porches. They are slender-branched but grow rapidly and with their handsome flowers, make a great show.

CLEMATIS, PANICULATA-The best known and most popular. Has small, creamy-white, deliciously scented flowers in great profusion in August. Entirely hardy.

CLEMATIS HYBRIDS-These are the large-flowering varieties, all of great beauty, not so vigorous or rankgrowing as the Paniculata but with very large individual flowers in July.

CLEMATIS, DUCHESS OF EDINBURGH-Double white.

CLEMATIS, HENRYII-Extra large, single white.
CLEMATIS, JACKMANII-The best of all; large, velvety, violet-purple flowers in great profusion.

CLEMATIS, MADAME EDOUARD ANDRE-Large, single, red flowers.

EUONYMUS RADICANS-See Evergreens on page I3. HONEYSUCKLES. Lonicera-All vigorous and rampant growers, suitable for covering porches and arbors. HONEYSUCKLE, HALL'S JAPAN. L. halliana-White flowers, changing to yellow; very fragrant; blooms all summer; foliage especially good and practically evergreen in the North; entirely so here. Altogether the best of the climbing Honeysuckles.

HONEYSUCKLE, SCARLET TRUMPET. L. sempervirens-Red Coral Honeysuckle. A native, strong grower that produces scarlet, inodorous flowers through the summer.

IVY, English. Hedera helix-See page I4.

JESSAMINE, YELLOW. Jasminum nudiflorum-Golden yellow flowers very early in spring.

JESSAMINE, WHITE. J. officinati-A popular climber, with very fragrant white flowers.

TRUMPET FLOWER. Bignonia radicans-A rapidgrowing vine with large, trumpet-shaped scarlet flower.

WISTARIA, CHINESE-One of the most elegant and rapid-growing of all the climbing vines; attains very large size, sometimes growing 15 feet or more in a single season; bears long racemes of pale blue flowers in spring and sometimes again in autumn.

WISTARIA, DOUBLE PURPLE-Similar in habit, but with double flowers of a deeper blue color.

WISTARIA, WHITE-Like the others, but with pure white single flowers.

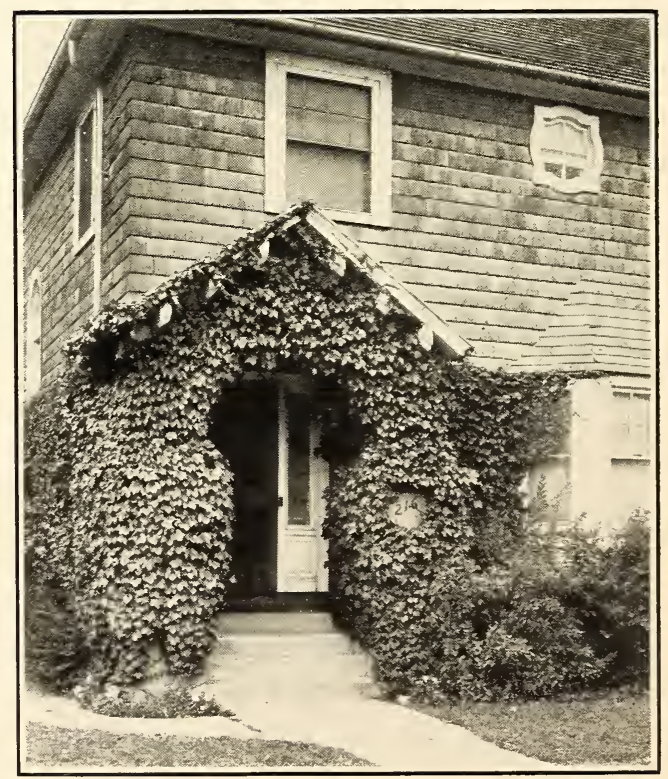

An attractive use of Ampelopsis Veitcbii 


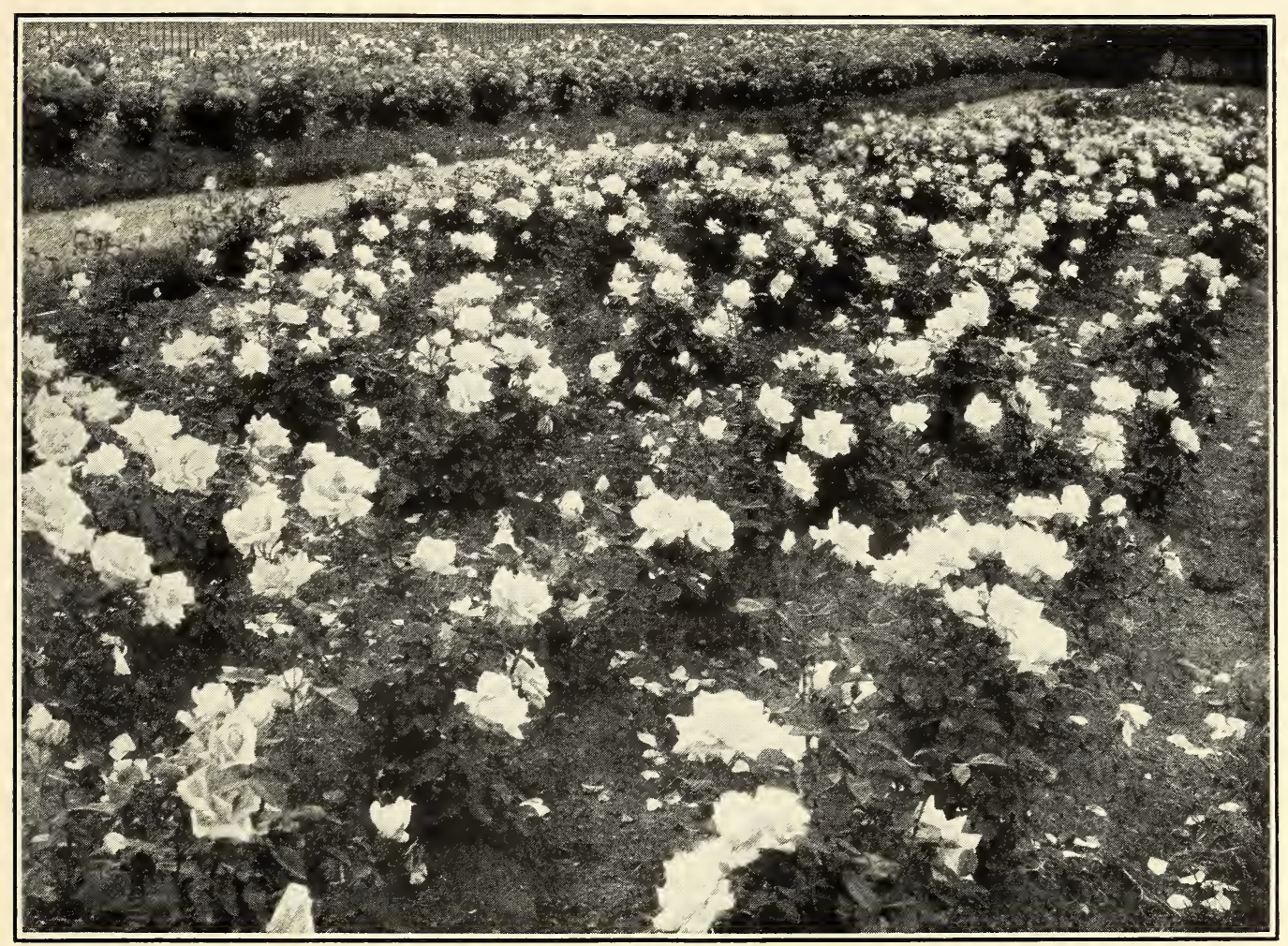

$A$ bed of the beautiful White Killarney in bloom

\section{Roses}

TEA, Hybrid Tea and Monthly-blooming Roses. The varieties in this general class are 1 marked by delicacy of texture, grace of form, fragrance and such wide range in colors as cannot be found in any other group of roses. They are everblooming in habit and in bloom from spring until frost. Some of the Teas are very tender; some of the Hybrid Teas are remarkably hardy, succeeding with but slight protection in Northern New York. With us here, they are by all odds the most valuable roses we have.

ALEXANDER HILL GRAY-Lemon yellow, deepening to golden yellow on opening. Large, full blooms with pronounced pointed center; free-flowering and highly tea-scented. One of the best for the South.

BON SILENE-Bright crimson-rose; large, beautifully formed buds with very long petals. A favorite in the South.

BRITISH QUEEN-A pure white rose, rarely exhibiting any suggestion of either cream or pink, so often found in nearly all other white roses. The buds are fine formed, the flowers full and double. Wherever British Queen grows well, it is a remarkable variety for color, size and form.

CATHERINE MERMET-Bright flesh color, full and beautiful, of fine form and one of the loveliest grown. Has been called by a famous grower, "the perfect rose."
COLUMBIA - Originally propagated for florists' growing under glass, Columbia has become popular as a garden variety-a hothouse rose that does equally as well outdoors. Large, double, finely formed blooms of deep pink; very vigorous and healthy and altogether a superior pink garden rose.

CRIMSON MAMAN COCHET-Grows vigorously and produces a great wealth of finely formed, fragrant blooms; buds are long, full and pointed with large petals; the color is a rich, bright red.

CRUSADER - One of the latest new roses; large and full blooms on strong stems; rich, velvety crimson.

DUCHESSE DE BRABANT-Flowers rather loose when fully open, but are rich and peculiarly colored: rosy pink, shaded with amber and salmon; makes a bushy plant and produces more blooms than any other throughout the summer. Fine for massing. 


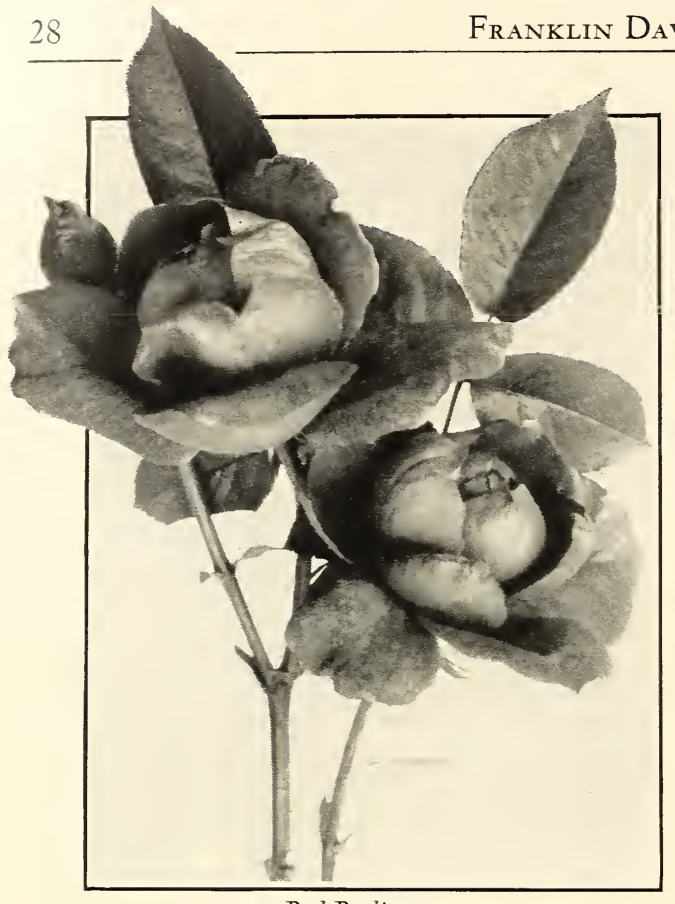

Red Radiance

FRANCIS SCOTT KEY-Fine, rich red; blooms of large size, very double, graceful and beautiful. One of the comparatively new roses.

GOLDEN OPHELIA-Long, pointed buds and rather full flowers of a bright golden yellow, without the pronounced pink of the original Ophelia. A healthy, vigorous rose that does well in the garden and blooms profusely.

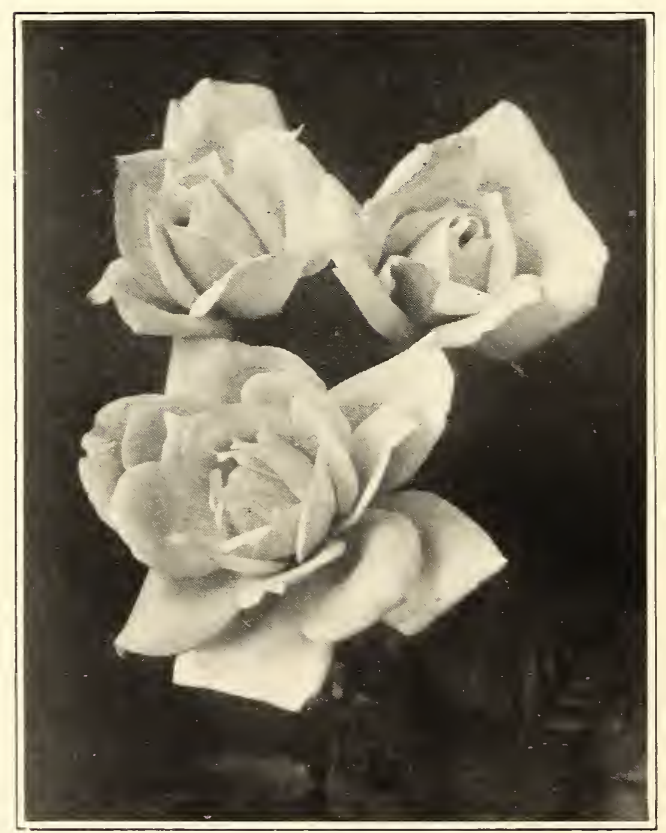

Sunburst
GRUSS AN TEPLITZ-An intense, dazzling red, almost scarlet. The buds and half-opened flowers are especially fine; on opening fully, the flowers are not full enough, but the dazzling color and the constant blooming make up for that. Easily the most outstanding variety in any garden.

HADLEY-Deep, rich, velvety crimson; buds are well formed and the blooms are large and double; especially fine fragrance.

HOOSIER BEAUTY-Glowing crimson-scarlet with darker shadings; velvety petals forming long buds and flowers of good substance. A good, vigorous grower, producing a flower on every stem; very fragrant.

HELEN GOULD-Rosy crimson; fine in bud or when open; full and double; grows well and blooms incessantly; one of the best for the South.

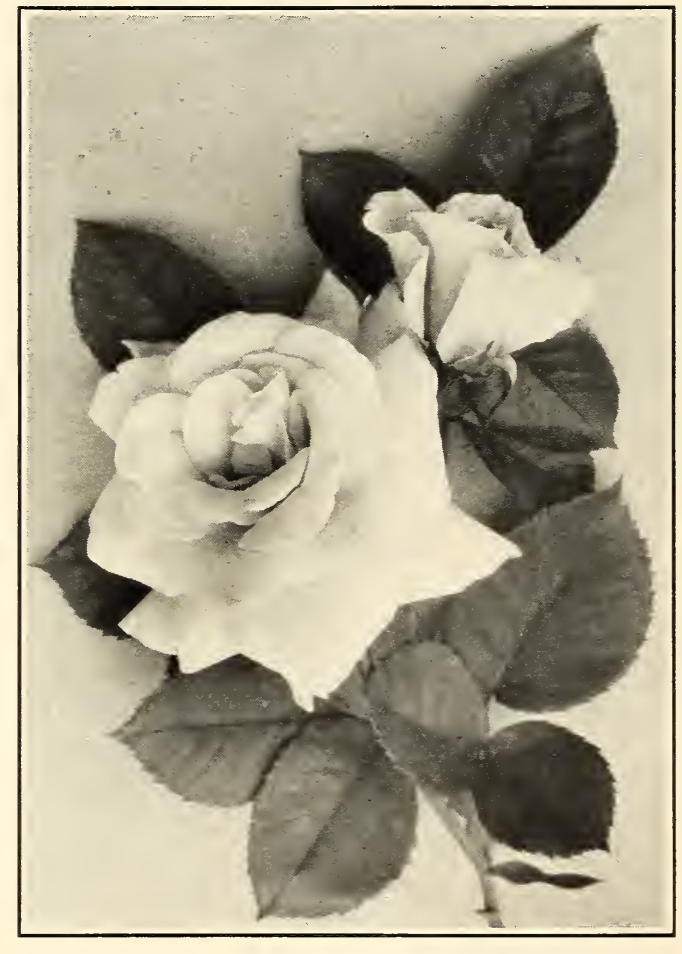

Opbelia

HERMOSA-Belonging to the Bengal, or China, race, and not of the Tea type, Hermosa is everblooming and the most popular bedding variety. The color is a rosy pink and the flowers are quite double and borne in great profusion.

IRISH FIREFLAME-Old gold, copper and orange shades and tinged with rich crimson; large, single flowers of sweet fragrance and never out of bloom.

ISABELLA SPRUNT-An old favorite and a grand rose for the South, with its strong, clean growth and its perfectly formed flowers of bright canary-yellow. 
JONKHEER J. L. MOCK-A remarkable rose with petals in two colors; the inside of the petals is a clear, silvery pink; the outside, a rich crimson; the buds are large and compact, the flowers full and showy. The general effect is that of a glorified La France. The growth is very strong and the plant blooms throughout the summer even in the driest weather.

KAISERIN-Long pointed buds and graceful, double flowers of creamy white and deliciously fragrant; one of the hardiest of the pure Tea roses.

KILLARNEY - Brilliant pink; long buds of large and waxy petals and open flowers good, but not very full; best in bud and half open; a superb rose for the garden, hardy for its class and continuous in blooming.

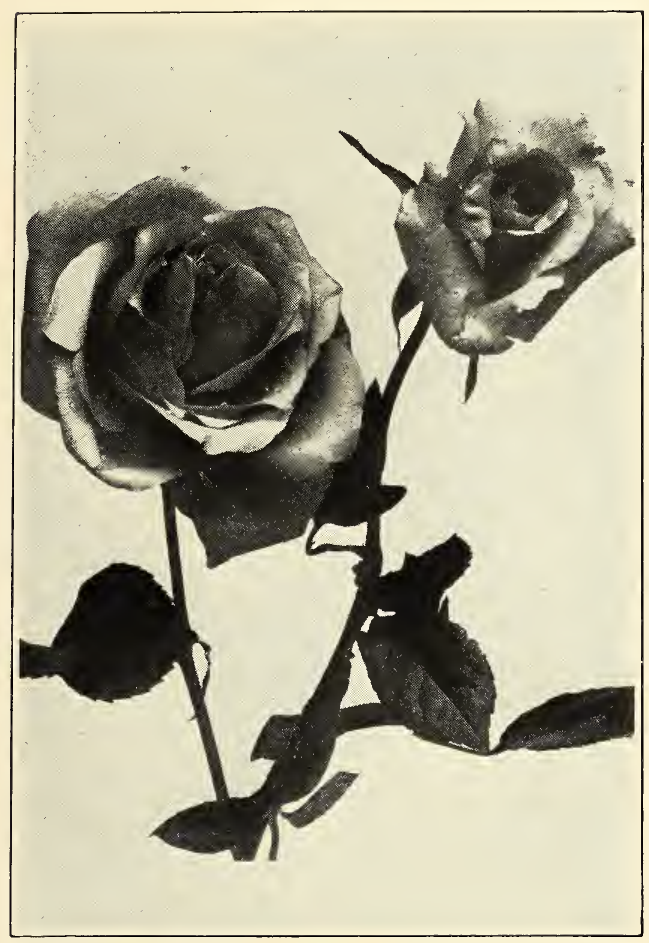

Papa Gontier

KILLARNEY BRILLIANT-Like the older Killarney, but with a livelier, more brilliant pink color.

KILLARNEY, WHITE-Similar to the Pink Killarney, but white.

KILLARNEY, DOUBLE WHITE-Like the White Killarney from which it sported, but with a purer white color and double the number of petals.

LADY HILLINGDON-One of the best of the favorite yellow roses. The color is deep apricot to orange; long, pointed buds; very free-flowering.

LA FRANCE-One of the earliest, if not the earliest, monthly roses. Silvery pink in color, with a fragrance unequalled by any other. La France needs feeding and severe pruning to give its best.

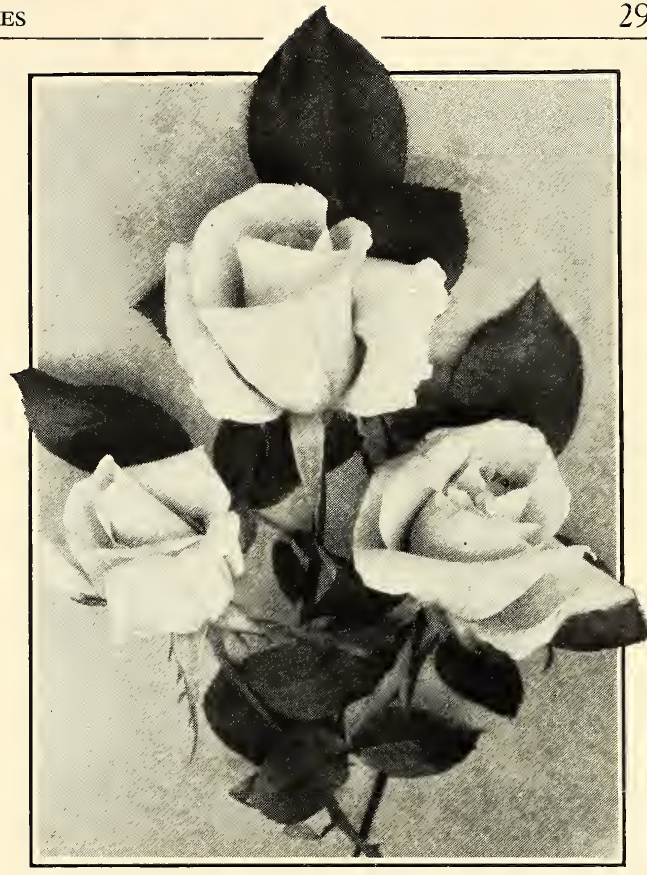

Madame Butterfly

MADAME BUTTERFLY-One of the best of the new roses. It is hardy in its class, makes a good, strong growth and blooms constantly. The buds are perfect in shape, the open flowers, full and double; the mingling of shades of yellow, apricot and pink, is most attractive. In three years, this has become one of the most largely planted roses in the country. It grows and blooms and produces a constant succession of wonderfully beautiful buds and blooms.

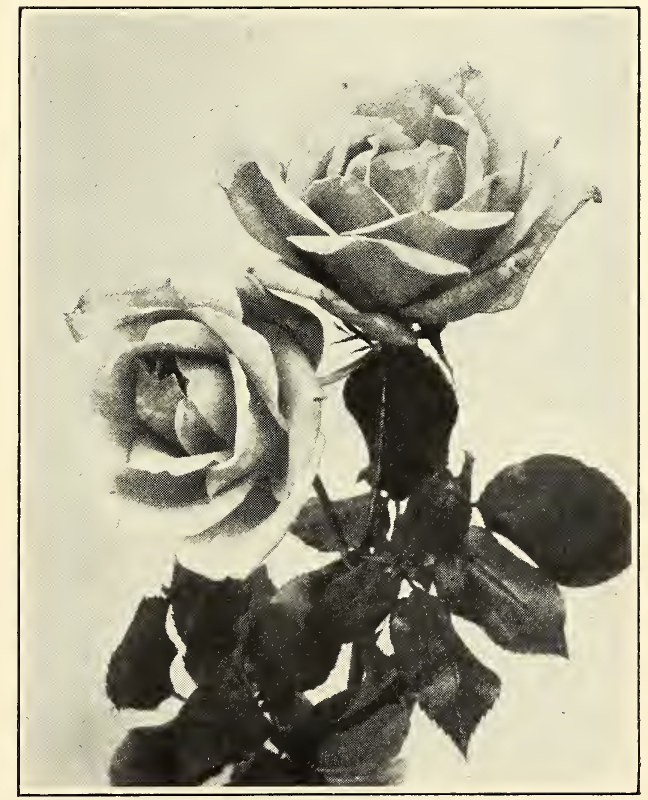

Jonkbeer J. L. Mock 


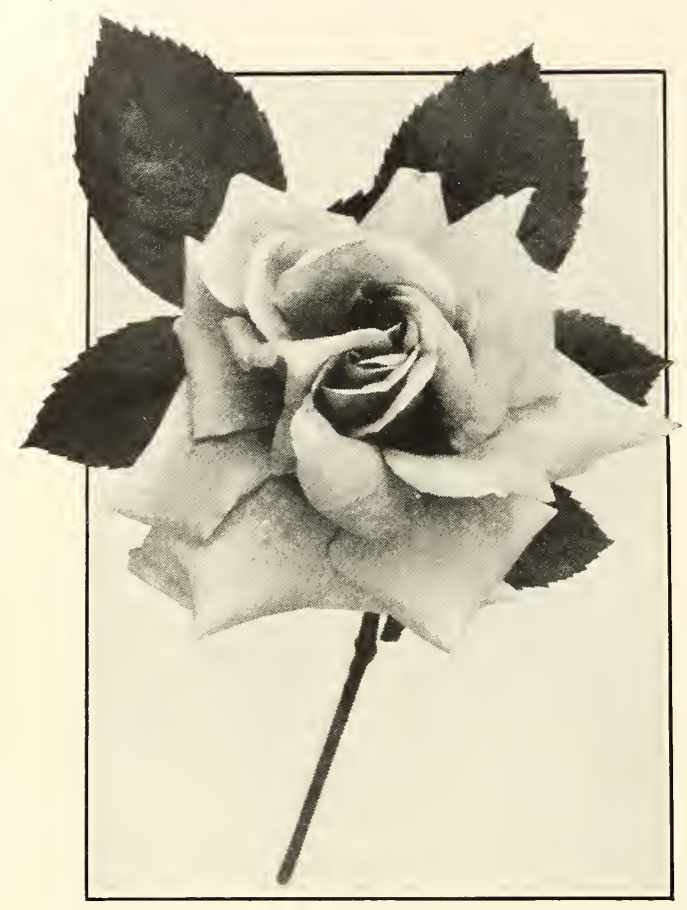

My Maryland

MAMAN COCHET-The Cochet roses are favorites wherever grown and they are nowhere more beautiful than here. Exquisite in bud, half open and full blown; very double; deep, rosy pink, the inside of the petals, silvery rose.

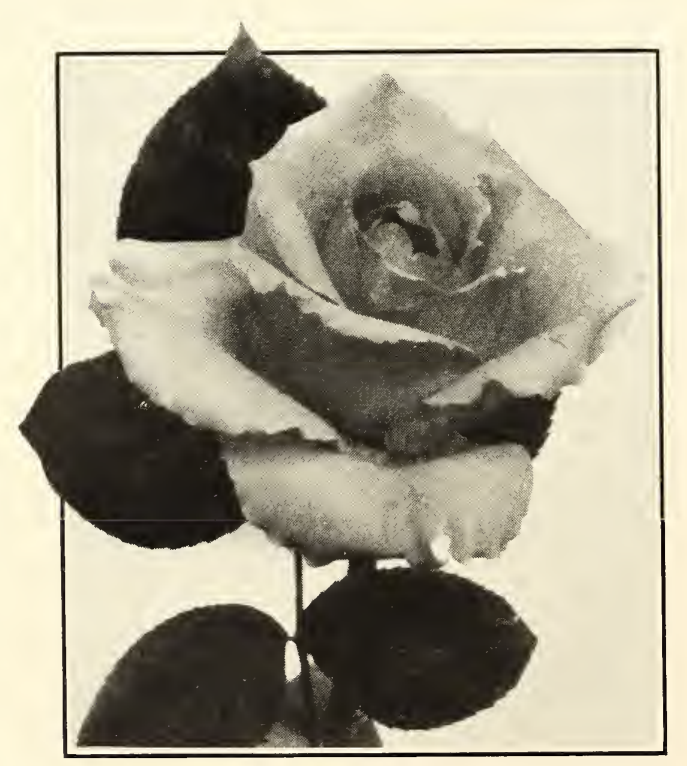

Hadley
MAMAN COCHET, WHITE-Similar in all respects to the Pink Maman Cochet, differing only in color; it is white and its exquisite buds and full double open blooms are always a delight.

METEOR-A free-blooming rich, dark velvety crimson rose of vigorous habit. Half open buds are remarkably fine.

MY MARYLAND-A salmon-pink of a very pleasing shade; long stems and long, pointed buds, very full in bloom and exquisitely fragrant.

NATALIE BOTTNER or Yellow Kaiserin-Delicate, creamy yellow; large, full and double; strong, healthy grower, blooming monthly.

OPHELIA-Brilliant salmon-flesh, shaded with rose on outer edges of petals, with center of pink and yellowish tints beautifully blended; fine in bud or open; fragrant; grows well and blooms constantly. One of the finest garden roses.

PAPA GONTIER-Deep crimson, passing to glowing crimson. Perfect in bud and when half open; makes a remarkably vigorous growth and blooms constantly; one of the very finest roses for the South.

PERLE DES JARDINS-Clear, golden yellow flowers of large size and good shape and substance; very fragrant; popular in the South.

RADIANCE-Rosy pink; fine, large buds and cup-shaped blooms, full and double; hardy, strong grower, flowering in great abundance through the entire season. One of the best roses for garden culture; always satisfactory.

RED RADIANCE-One of the best everblooming garden roses and hardy enough for New York. A bright, cheerful red; good buds and in cupped shape, the petals give the open bloom an effect of decided fullness; grows well, blooms continuously from spring till frost and ranks with the very best north or south.

RENA ROBBINS - White or lemon, with orange center; large blooms on stiff stems; a good bedding variety.

RHEA REID - Good sized blooms, very double, with inner petals shorter than outer petals; especially fine in bud; deep, brilliant red, fragrant and free blooming.

RICHMOND-Brilliant scarlet-crimson; very pointed center which holds until the bloom is wide open; makes a good growth and is very persistent in blooming.

SAFRANO-Saffron and apricot shades; perfect in bud; an old Southern favorite.

SUNBURST-Fine, rich golden yellow; long, pointed buds and large full flowers on strong stems; vigorous and free-blooming for a yellow rose, with blooms of unusual size in this class.

WILLIAM R. SMITH-Creamy white with shadings of pink; perfectly shaped in bud and bloom; branches freely, makes a strong growth, blooms abundantly and is especially good as a bedding rose in the South. 


\section{Hardy Hybrid Perpetual Roses}

$A^{S}$ a race, these are older than the newer Hybrid Teas, and while they have been elbowed out of the way by the monthly blooming roses, yet they are fast regaining whatever they lost of popularity. Their many fine qualities should make sure and permanent their place in the garden. They are all perfectly hardy, make taller and stronger growth than the Hybrid Teas; they bear flowers of great-sometimes immense-size and include rich and wonderful colors. They require little pruning and no protection here. They bloom in great profusion in June, usually again in the fall after rains and some bloom at intervals through the summer.

AMERICAN BEAUTY-Large, full and double; reddish crimson in color and very fragrant. While American Beauty is a good garden rose, it must not be expected that outdoor blooms make the long stems or reach the perfection of those grown by florists in hothouses.

ANNE DE DIESBACH - Clear, bright carmine; very large and finely shaped; full and fragrant.

FRAU KARL DRUSCHKI-Classed as a Hybrid Perpetual because of its absolute hardiness, this variety has nearly every characteristic of the Hybrid Tea class. The buds are pointed, of great size and set in a frame of close-growing foliage making each flower a bouquet. White, with a tinge of pink on the outer petals, while the open flower is pure white. The grow th is exceeding vigorous, the foliage rich, dark green; and no rose blooms more constantly or in greater profusion.

GENERAL JACQUEMINOT-The tavorite old Jack Rose, known and loved everywhere and still one of the finest of the red roses.

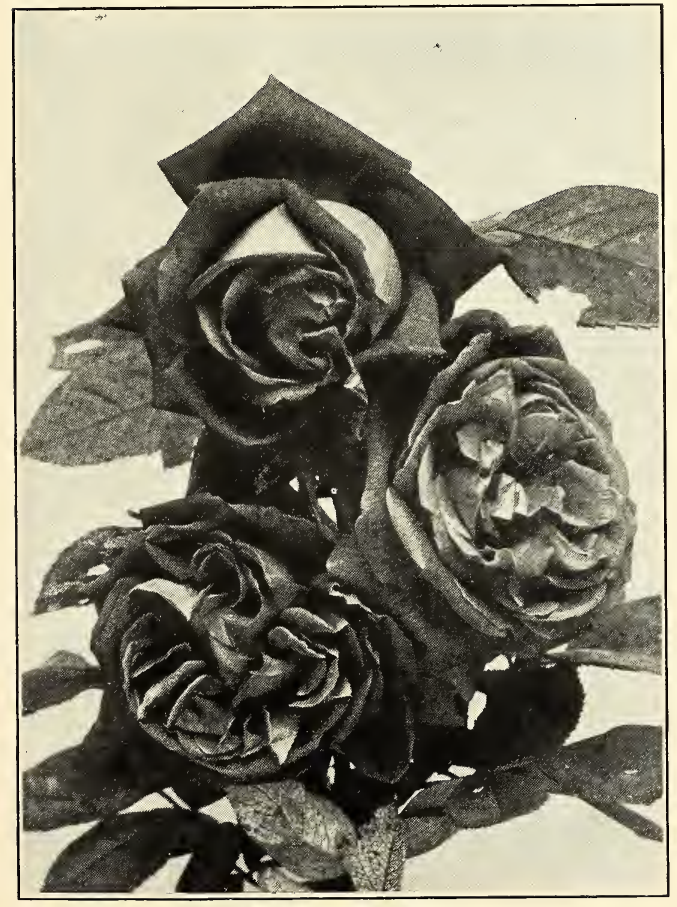

Marshall P. Wilder

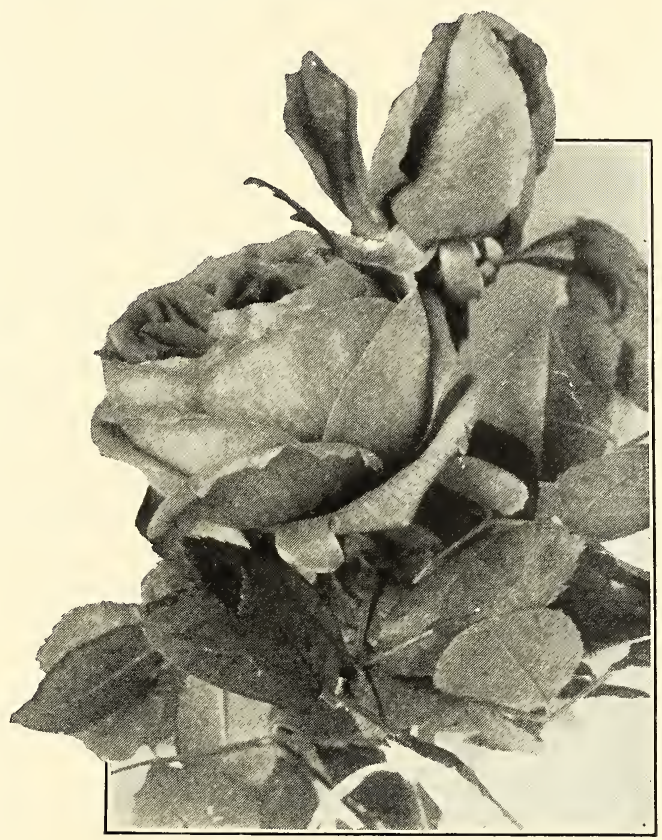

American Beauty

MADAME CHARLES WOOD-A splendid crimson, extremely double, full and of large size. A very free bloomer.

MAGNA CHARTA-Extra large, full flowers, very double, finely formed and bright cherry red in color. Grows very tall and makes numerous long, strong shoots from the ground. Excellent in every way.

MARSHALL P. WILDER-Deep, rich, glowing red; extra large and full flowers, borne freely on strong stems.

PAUL NEYRON-The largest individual rose in cultivation; finely shaped, double, rosy pink. A fine old favorite.

PRINCE CAMILLE DE ROHAN-Sometimes called The Black Prince. Very dark, velvety red, shaded with maroon, glowing in the sunlight.

ULRICH BRUNNER-Extra large, full, globular flowers of rich crimson, flamed with scarlet.

VICK'S CAPRICE-An oddly marked variety whose pink petals are striped with white and red. 


\section{Climbing Roses}

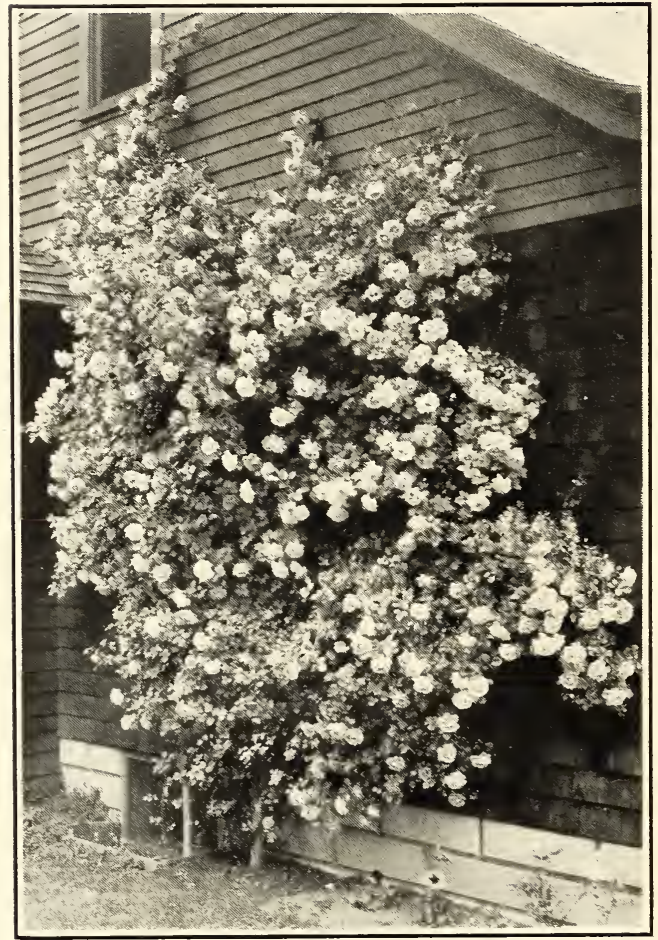

Climbing American Beauty

CLIMBING AMERICAN BEAUTY-A seedling of the well-known American Beauty with crossings that give it the climbing habit, a brighter red color, a longer blooming season, without any loss of hardiness or other desirable qualities in the parent. The individual blooms are of a size and quality rare in climbing roses.

BALTIMORE BELLE-Pale blush, changing to carmine, rose and white; double; a vigorous grower and an old friend in many old-fashioned gardens.

CLOTH OF GOLD-One of the best Climbers for the South and often seen on verandas; clear golden yellow; buds and blooms of good size, full and well formed. An old favorite here.

CRIMSON RAMBLER--When in bloom, it is a great sight, with its immense clusters of brilliant red blooms. Makes a remarkably strong, quick growth and is probably the most popular of the Rambler roses.

DR. W. VAN FLEET-A hardy climbing rose with individual flowers of great size and beauty; double, finely formed and of a clear, flesh pink color; fragrant. Very vigorous, with healthy, bronze-green foliage. Recommended highly.

DOROTHY PERKINS - A Rambler of Wichuriana foliage and vigor, ideal for covering old fences or training on trees, old stumps or arbors. Bright pink flowers in immense clusters. One of the best.
EMPRESS OF CHINA-Esteemed for its remarkably quick and strong growth; the flowers are produced in quantity, a soft, dark red changing to a lighter red or pink.

EXCELSA-A bright red variety, otherwise of the same habit and characteristics as Dorothy Perkins. The foliage is especially good; rich green, and does not mildew.

GARDENIA--Bright yellow, fading to cream on opening; very lasting foliage; hardy and free flowering; has been called the "Hardy Marechal Niel."

LADY GAY-Delicate shell-pink. The individual flowers are very full and compact and are borne in great clusters that droop with their weight of beauty. Perfectly hardy, with fine, healthy foliage; fine for growing on trellises, porches, or arbors.

MRS. ROBERT PEARY - Ivory white, pointed buds and good double blooms, identical with Kaiserin, its parent, except in habit of growth; hence its other name, Climbing Kaiserin.

PAUL'S SCARLET CLIMBER-A comparatively new variety that has created a veritable sensation on account of its vivid, intense scarlet color: the brightest red in any climbing rose. Of good strong habit, branching freely; the flowers are of medium size, tairly double, borne in clusters during an exceptionally long season. REINE MARIE HENRIETTE-A climbing Tea rose and in the South, wherever hardy, it is superb, the flowers having the size, form and color of the best bush roses; color, rich, cherry crimson. One of the finest roses grown.

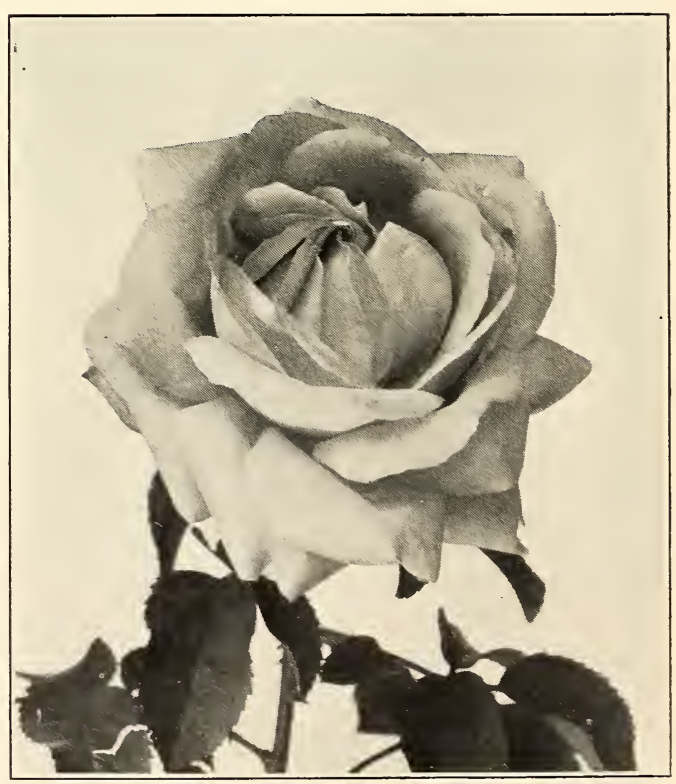

Dr. Van Fleet 
SEVEN SISTERS - Large clusters in which the individual flowers vary from rosy-red to blush-white.

SHOWER OF GOLD-Deep golden yellow and orange flowers in large clusters; a strong plant with foliage of Wichuriana type.

SILVER MOON-Clear, silvery-white with prominent yellow stamens; flowers of great size, slightly cupped and single; fragrant and free-blooming; a vigorous climber that has become very popular everywhere.

TENNESSEE BELLE-Bright pink flowers in clusters.
WHITE DOROTHY PERKINS-Similar to the pink variety of the same name, but pure white; hardy, vigorous and blooming in great trusses of small, double white blossoms.

WHITE RAMBLER - Hardy, of Rambler type with semidouble flowers in large clusters.

YELLOW RAMBLER - Hardy yellow roses are rare and those of the Rambler class are desirable where hardiness is a requisite. The blooms are a golden yellow, fragrant and borne in clusters.

\section{Wichuriana, or Memorial Rose}

A distinct and valuable species of prostrate and rapidcreeping growth largely used for covering the ground, stumps of trees, pillars, posts, trellises, rocky slopes and embankments. For the last named purpose, nothing is better; it lies flat on the ground and makes roots along the whole length of its branches; it is therefore ideal on retaining walls and embankments. Hardy, and will survive the severest winters, remaining green up to Christmas. The flowers are single, pure white with pronounced yellow antlers and delightfully fragrant.

\section{Rosa Rugosa (Japanese Rose)}

Large, single flowers of white or red, followed by very large and quite ornamental red fruits in late summer and autumn. The growth is rough and sprawling; the leaves are large, rich and glossy and unaffected by mildew or insects, the foliage alone being sufficient reason for planting Rugosas in clumps or shrubbery groups or as hedges. They are admirably suited to all these uses. Hardy everywhere, with abundant foliage that stays green and freshlooking all summer.

\section{Moss Roses}

Who does not love the old Moss Roses? Their mossy buds are the very symbol of beauty and romance. They are all perfectly hardy and long-lived and are among the charms of many an old garden. We offer both White and Crimson.

\section{Baby Ramblers}

These are called Baby Ramblers, but they are not ramblers: they are like the ramblers in blooming in large clusters; they are very dwarf, bushy, compact little bushes, perfectly hardy, with dark green foliage and bloom continuously through the season. The colors are Red, White or Pink.

\section{Tree Roses}

These are budded on single stems at 3 or 4 feet high and make pretty litcle standards with bushy heads. They are very popular in European gardens. We have Tree Roses in assorted colors and the best varieties for growing in treeform.
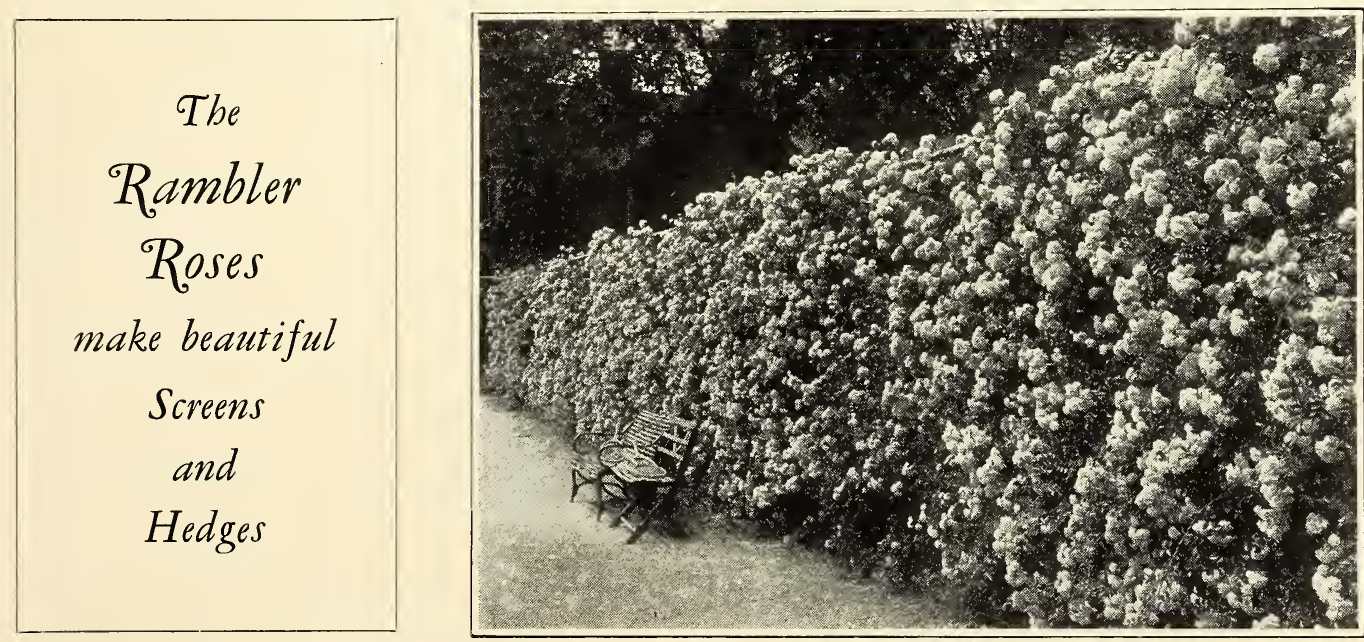


\section{F R U I T DEPAR T M E N T Apples}

$T$ HE Apple is the staple fruit of America, growing almost everywhere except in the South1 ern Gulf Coast, where only a few varieties fruit well. This selection of varieties, carefully made out of many years' experience, includes the best of the staple varieties; yet all are not recommended as equally desirable nor suitable for all sections. Special adaptability to certain localities is mentioned below.

\section{Summer Apples}

EARLY HARVEST-Large, round, yellow with nearly white flesh; tender, juicy and crisp with a rich, subacid flavor. A moderate grower, but prolific bearer. Has no superior among early apples. June and july.

EARLY RIPE-Large, yellowish white with white flesh, juicy and sub-acid. Fine for the table or for cooking. Tree hardy and vigorous. Coming immediately after Early Harvest, its large size and handsome appearance make it a profitable orchard varietv. First of July.

RED ASTRACHAN-Fairly large, covered with bright crimson; rich, juicy, acid but excellent when fully ripe. The best early red apple. July.

RED JUNE-Bears early and is very productive. Fruit of medium size, dark crimson with tender, fine-grained white flesh, juicy and sub-acid. June and July.

STARR - Very large, showy fruit of pale green often with a handsome blush on the sunny side; very early, ripening the first week in July and will keep in good condition until September. A good shipper for so early an apple. Pleasant, sub-acid flavor and excellent for cooking. Tree vigorous, early-bearing and produces a crop every year.

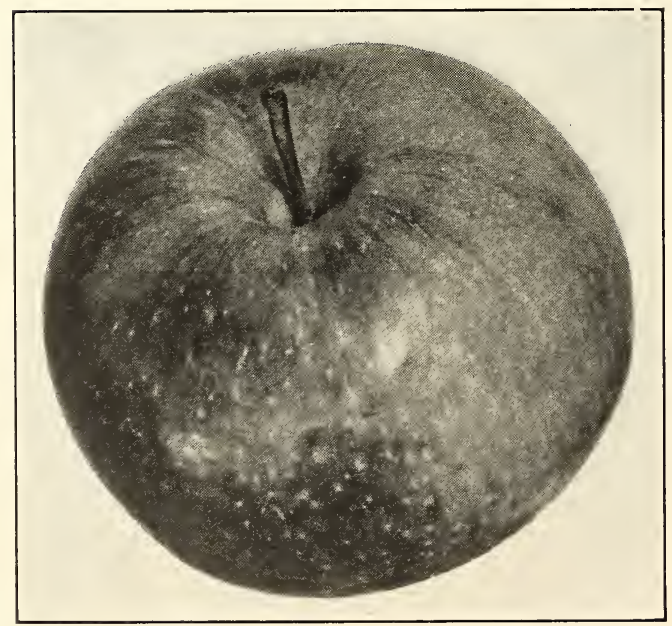

Red Astrachan
WILLIAMS-Large, red, handsome; an excellent eating apple and good for cooking; mid-season; always marketable.

YELLOW TRANSPARENT-Good medium size, pale yellow when ripe; bears young, makes a vigorous, upright growth and is very prolific. Among the earliest, ripening in July.

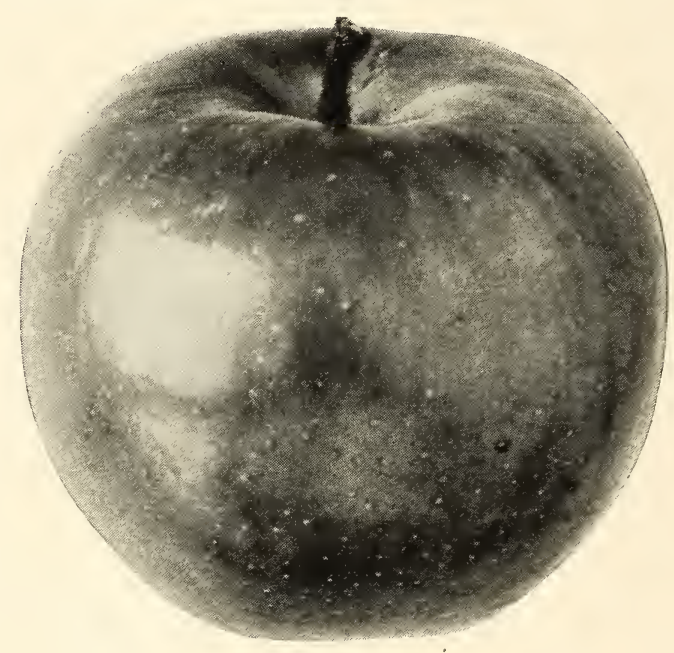

Starr

\section{Autumn Apples}

FALL PIPPIN-Very large, round, yellowish green, turning rich yellow when ripe; excellent quality. Succeeds almost everywhere. September to December.

GOLDEN SWEET-Rather large; rich yellow; juicy, tender and'sweet. August.

GRAVENSTEIN-Large, roundish; striped with red; flesh tender, juicy, very rich, sub-acid, of high flavor; handsome; excellent quality. Does well everywhere. August.

MAIDEN'S BLUSH-Pale yellow, with a fine, evenly shaded red cheek; of large size; flesh tender, sprightly, with a pleasant sub-acid flavor; makes a handsome, spreading tree that bears large crops. August to October.

SUMMER RAMBO-Very large, yellow, striped with red; mild, sub-acid, with a pleasant flavor. September. 


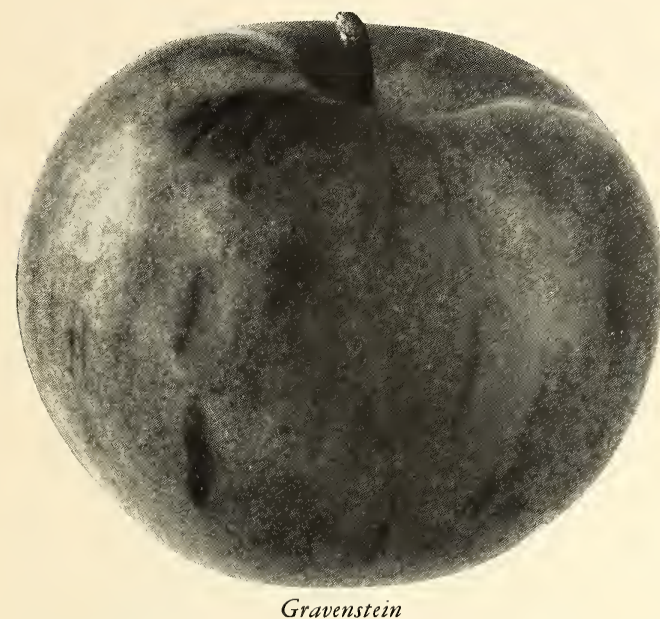

OLDENBURG (Duchess)-Medium to large, very handsome golden yellow nearly covered with streaks of crimson; flesh tender, juicy, pleasant. Tree very hardy, vigorous and bears heavily. August.

SMOKEHOUSE-Large, with red streaks on yellow ground; flesh yellowish white, firm, juicy, crisp and rich with a fine, sub-acid flavor; very productive; unsurpassed for cooking. September to December.

\section{Winter Apples}

BALDWIN-Large, roundish, yellow almost covered with red; crisp, rich, juicy, sub-acid; a vigorous grower, bearing heavily. Succeeds well in western Maryland and the mountains of Virginia, but drops its fruit too early in or near the tide-water section. October to January.

BANANA-Medium to large; golden yellow, beautifully shaded with crimson; flesh yellow, fine-grained, subacid and of high quality. A remarkable keeper; tree hardy, strong grower, early bearer. A profitable market variety. November to May.

BEN DAVIS-Large, handsome, striped; tender, white flesh; tree a healthy, vigorous grower and a regular, heavy bearer. While not of dessert quality, yet one of the most profitable market apples. Will keep until mid-summer.

BONUM-Large; light to dark red; flesh yellow, firm, sub-acid; of fine quality, an excellent eating apple, one of the best for the South. We recommend it highly. October to January.

DELICIOUS - A high quality eating apple, of unsurpassed flavor. Brilliant red in color, peculiarly ribbed at the nose; flesh yellow, remarkably juicy and of mild, delicious flavor. Tree, vigorous and hardy. Commands highest prices and recommended as a perfect dessert apple. December to March.

GANO-Like Ben Davis, but more highly colored. A good keeper.
FALLAWATER-Large, yellowish green with a dull red cheek; flesh greenish white with a mild, slightly sub-acid flavor; tree a strong grower and a good bearer. One of the dependable varieties. November to February. GRIMES' GOLDEN-A high quality apple, of rich, spicy and refreshing quality; medium to large, deep golden in color, with yellow flesh. Tree, hardy, vigorous and productive. January to March.

JONATHAN-Small to medium, round, uniform, with yellow skin nearly covered with dark red; very tender and high flavored; deservedly popular; keeps well. November to April.

LADY - A wonderfully beautiful little apple, used, because of its small size and bright coloring, more for decorative purposes at Christmas. Very small, clear yellow, with a pronounced and handsome red cheek; a great bearer.

McINTOSH-Large, roundish, nearly covered with bright red; flesh white, tender and juicy; excellent quality. Tree is very hardy and a strong grower. November to February.

NORTHERN SPY-Medium to large, rather flattened, striped and nearly covered with dark crimson on the sunny side; flesh white, fine-grained, tender, slightly sub-acid. Both leaf and blossom buds open a week later than most other apples. A variety of high quality, but we do not advise its planting south of Pennsylvania, except in the mountain regions. November to February.

NORTHWESTERN GREENING-Large, smooth, greenish yellow; flesh fine-grained, firm and juicy, of good quality. Extremely hardy; a late keeper. January to April.

PARAGON-Large, deep red; sub-acid; an abundant and early bearer. A seedling of Winesap which it resembles in many ways, but superior to that old favorite. Is a strong grower, bears early and abundantly. Has few equals as a winter apple. December to April.

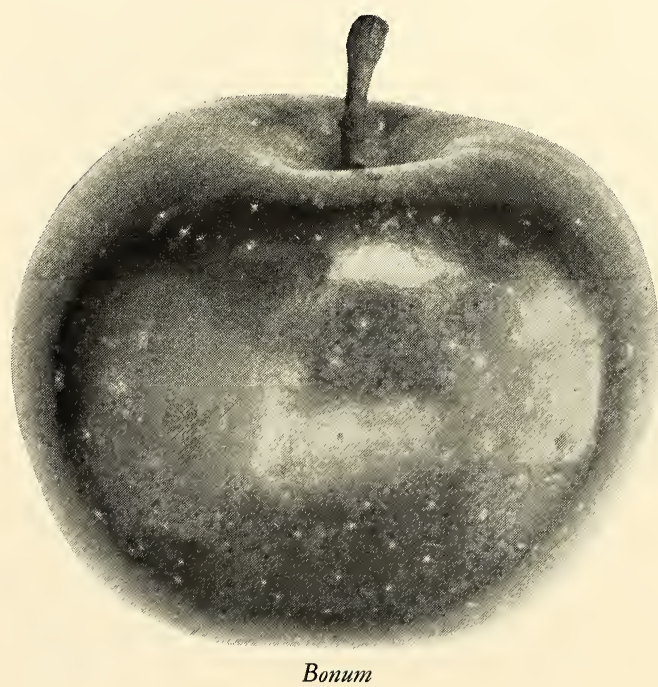




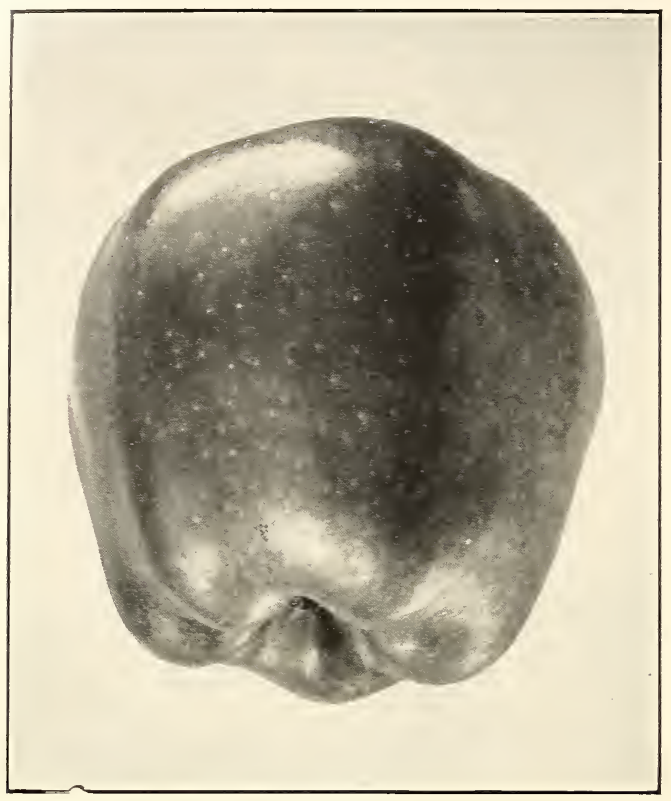

Delicious

ROME BEAUTY - Large, rellow, striped and splashed with red. On account of its size, beauty and great productiveness, is a profitable market variety. Bears regularly and can always be depended on for a full crop. November to January.

STARK-Large, with greenish skin, partly covered with red; mild sub-acid. Tree makes a strong growth, is hardy and bears annually; a profitable orchard variety and a long keeper.

STAYMAN'S WINESAP-Large, bright red, of fine quality. An improvement in every way, on the original Winesap and one of the finest apples in cultivation. In size, flavor, color and keeping quality it far surpasses Winesap and is fast displacing that older variety. Tree, a strong grower, irregular and drooping in habit and adapts itself readily to different soils and situations.

WEALTHY-Of medium size, whitish yellow ground, shaded with deep red, striped or entirely overlaid with red; flesh white, fine-grained, stained with red; tender, juicy, and of very good quality. Extremely hardy.

WINTER PARADISE-Large, roundish and regularly formed; skin fair and smooth, dull green when picked, with a brownish blush; flesh white, juicy, sprightly and sweet; productive and of excellent quality. Norember to February.

WINESAP-Of medium size, slightly oblong in shape, uniformly covered with fine, dark red except for an occasional yellow ground when shaded; flesh yellow, firm, crisp, with a rich, high flavor. Winesap stands among the finest of all apples; it is a high quality table variety; it has few equals as a cider-producer; it is one of the best keepers; and it bears regularly and abundantly. We recommend it highly, as a superior apple.
YELLOW NEWTOWN-Large, round, somewhat irregular; smooth, yellowish green, turning yellow when ripe; flesh yellow, firm, juicy, acid but rich and extremely agreeable. No apple stands higher in the marker than New town or brings so high a price; and in no part of America are apples grown that equal the Newtowns of the Piedmont region and some parts of the ralley of Virginia. It needs a deep, warm soil to bring it to perfection.

YORK IMPERIAL-Of medium size; greenish yellow nearly covered with bright red; flesh tender, crisp, juicy, aromatic; bears enormously and hangs long on the tree; a good keeper, retaining its flaror to the last.

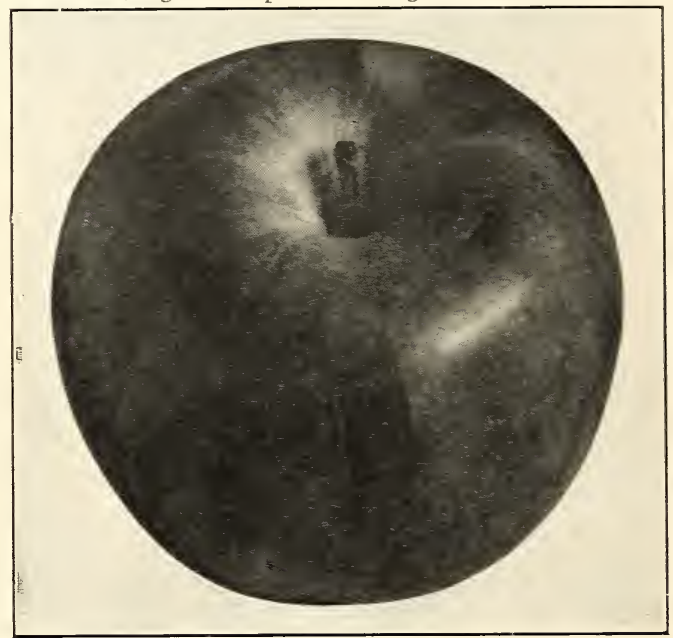

Stayman's Winesap

\section{Crab Apples}

All are small, acid, rery ornamental and useful for making jellies, preserves and sweet-pickles.

GENERAL GRANT-Large for a Crab; round, dark red; September.

HEWES - Famous as a cider apple; immensely productive; small, striped, rery juicy. October to December.

HYSLOP-A large Crab, produced in clusters; dark, rich red; good for cooking or for cider.

RED SIBERIAN-Very small, but beautiful; yellow with a brilliant scarlet cheek; very productive, bears young and is esteemed for cooking. September to October.

TRANSCENDANT-Largest fruit of any Crab; golden yellow with brilliant red cheek; sub-acid, mild, pleasant and agreeable as an eating apple when ripe; tree grows rapidly and produces good crops. Recommended as the largest, handsomest and best Crab. September.

WHITNEY-Large and striped; pleasantly sub-acid; tree extremely hardy, vigorous and productire. August.

YELLOW SIBERIAN-Very small, pretty yellow fruits that are ornamental and also fine for cooking or preserving. The tree is shapely and handsome and in bloom or in fruit, is well worth a place in any planting of ornamental trees. 
Varieties Best Suited to Tidewater Virginia and Eastern- and Western-Shore Maryland Summer Varieties

Red June

Early Harvest

Bonum

Fallawater

Ben Davis

Delicious

Red June

Early Harvest

Bonum

Maiden Blush

Ben Davis

Delicious

Fallawater

Gano

$\begin{array}{ll}\text { Early Ripe } & \text { Red Astrachan } \\ \text { Gravenstein } & \text { Starr }\end{array}$

For Late Summer and Autumn

Gravenstein Summer Rambo

Maiden Blush

Oldenburg

For Late Autumn and Winter

$\begin{array}{ll}\text { Jonathan } & \text { Paragon } \\ \text { Lady } & \text { Stayman Winesap }\end{array}$

Yellow Transparent Williams

Wealthy

York Imperial

Varieties Best Suited to Piedmont, Virginia

$\begin{array}{cc}\text { Early Ripe } & \text { Summer Varieties } \\ \text { Gravenstein } & \text { Red Astrachan } \\ \text { Starr }\end{array}$

For Late Summer and Autumn

Smokehouse Oldenburg Wealthy

Summer Rambo

For Late Autumn and Winter

$\begin{array}{ll}\text { Grimes } & \text { Paragon } \\ \text { Jonathan } & \text { Paradise Winter } \\ \text { Lady } & \text { Sweet } \\ \text { Newtown Pippin } & \text { Rome Beauty }\end{array}$

Stayman Winesap

Stark

Winesap

York Imperial

Varieties for the Valley of Virginia and West Virginia and Western Maryland

Carolina Red June

Early Ripe

Oldenburg

Fall Pippin

Baldwin

Bonum

Ben Davis

Delicious

Early Harvest

Red Astrachan

Bonum

Fall Pippin

Baldwin

Ben Davis

Grimes

Jonathan

\section{Summer Varieties}

$\begin{array}{ll}\text { Early Harvest } & \text { Starr } \\ \text { Red Astrachan } & \text { Yellow Transparent }\end{array}$

For Late Summer and Autumn

$\begin{array}{ll}\text { Fallawater } & \text { Maiden Blush } \\ \text { Gravenstein } & \text { Smokehouse }\end{array}$

For Late Autumn and Winter

Fallawater Lady

Gano Newtown Pippin

Grimes

Jonathan

Paragon

Winter Paradise

Varieties Best Suited to Pennsylvania and the West

Summer Varieties

Starr
Williams

Early Ripe

For Late Summer and Autumn

Fallawater Maiden Blush

Gravenstein

Oldenburg

For Late Autumn and Winter

$\begin{array}{ll}\text { Northern Spy } & \text { Rome Beauty } \\ \text { Paragon } & \text { Stark }\end{array}$

Varieties Best Suited to the South

Summer Varieties

Red June

Early Harvest

Yellow Transparent

Early Ripe

Starr

For Late Summer and Autumn

Bonum

Gravenstein

Fall Pippin

Oldenburg

For Late Autumn and Winter

Ben Davis Paragon Stayman Winesap York Imperial Jonathan Stark Winesap

Rome Beauty

Stayman Winesap

Winesap

York Imperial

Yellow Transparent

Smokehouse

Wealthy

Stayman Winesap

York Imperial 


\section{Pears}

WHILE Pear trees will succeed in most soils, they do best in heavy loam or clay soils. Standard trees - that is, those budded on pear roots-are best for orchard planting; Dwarf trees-or pears budded on Quince roots-are recommended for the home grounds and small gardens. Nearly all varieties of Pears should be gathered two weeks before maturity and ripened in the house, when their juiciness and flavor will be greatly increased.

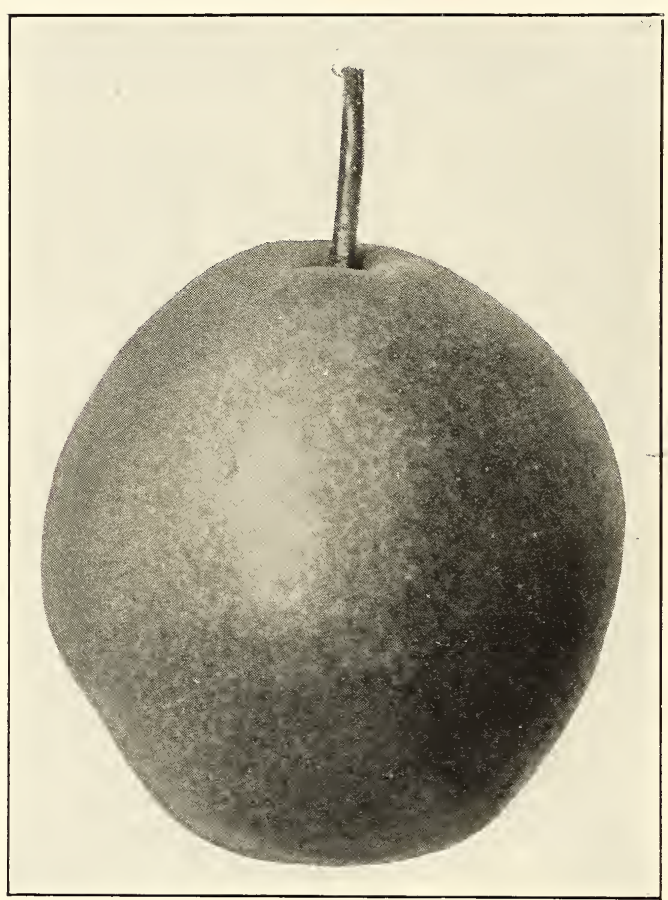

Garber

\section{Summer Pears}

BARTLETT - Large and beautifully shaped; yellow, with a soft blush on the sunny side; flesh white, very finegrained and buttery, sweet, very juicy, with a highly perfumed, vinous flavor. Bears young and well; one of the best pears. July and August.

CLAPP'S FAVORITE-A firsi-rate early variety, ripening a week or ten days before Bartlett which it resembles in appearance; large, with yellowish green smooth skin, dotted and shaded with red next to the sun; flesh yellowish white, juicy and melting; of very good quality. Last of July.

KOONCE-Early; a vigorous grower and good bearer; handsome yellow fruit but not of first quality; dependable and desirable.

MANNING-Small, yellow with red cheek; flesh white, juicy, melting, sweet and sprightly; tree hardy and very productive. August.

\section{Autumn Pears}

ANGOULEME. Duchesse-Very large; dull, greenish yellow, streaked and spotted with russet; flesh white, buttery and very juicy, with a rich, pleasant flavor. Especially recommended as a dwarf. September to November.

ANJOU--Large, greenish, sprinkled with russet, often shaded with dull crimson; flesh whitish, buttery, melting, with a high, rich, vinous excellent flavor; very productive; does well also as a dwarf. October and November.

BLIGHTPROOF-A valuable ironclad against blight. Of Sand Pear type; large to very large, smooth, beautiful yellow; flesh tender and juicy; tree an upright, strong grower; bears young and enormously; an annual bearer. August and September.

FLEMISH-Large, pale yellow, nearly covered with light russet, becoming, at maturity, reddish brown on the sunny side; flesh yellowish white, not fine-grained, but juicy, melting, sugary and rich; tree is hardy and bears early and abundantly. The fruit should be gathered earlier than most pears, and house ripened. September.

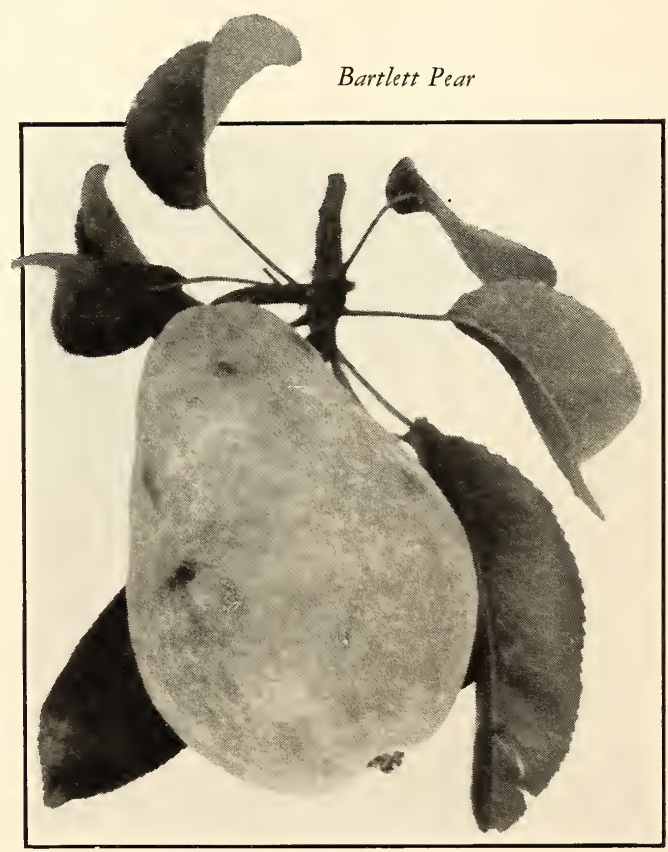




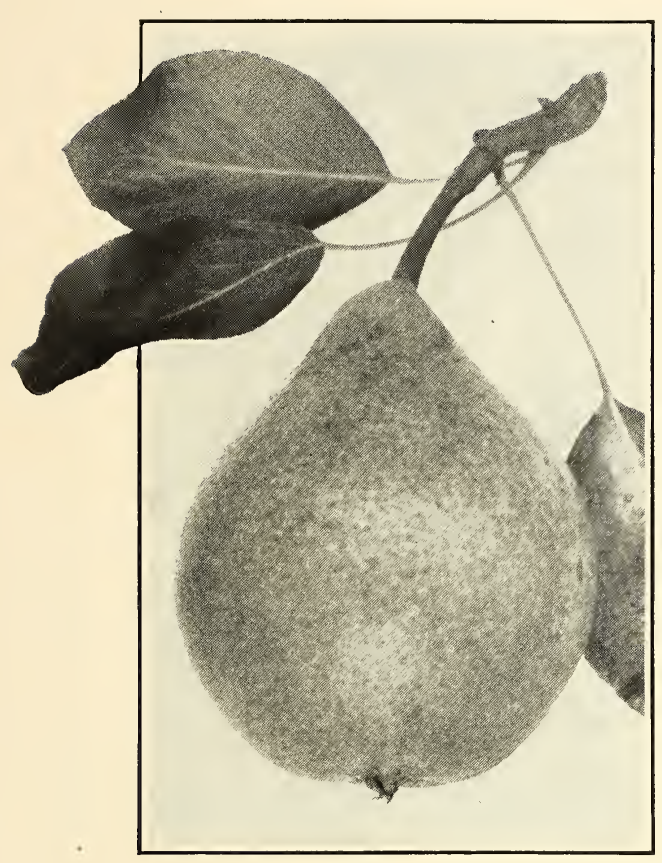

Clapp's Favorite
GARBER-Resembles Kieffer, but larger and of better quality; tree a strong grower, bears early and heavily; an excellent canning variety. September and October.

KIEFFER-Medium to large, golden yellow with red cheek; tree very vigorous, bears young and yields an abundance of fruit every year. When gathered before maturity and house ripened, becomes of good quality. The best for canning. Should be planted always as a Standard. Makes an ornamental tree.

SHELDON-Of medium size, yellow on greenish russet, with a highly colored cheek; flesh coarse, but melting, juicy and with a brisk, highly perfumed flavor; very productive; grown only as a standard. October.

SECKEL - Small; brownish green at first, becoming dull yellowish brown with russety red cheek; flesh whitish, buttery, rich and melting with a peculiarly spicy flavor and aroma. The healthiest and hardiest tree among pears and accepted everywhere as the highest standard of quality in the fruit. August and September.

\section{Winter}

LAWRENCE-Large, yellow covered with brown dots; flesh whitish, slightly granular, sometimes buttery, with a very rich, aromatic flavor; tree healthy, hardy and productive. November and December.

To aid the inexperienced in making their selections, we have carefully prepared the following lists-one for cultivation as standards on Pear stocks, the other to be grown as dwarfs on the quince root:

Anjou

Angouleme

Bartlett

Anjou

\begin{abstract}
Blight Proof
Clapp's Favorite

Flemish Beauty
\end{abstract}

\section{For Standards}

$\begin{array}{ll}\text { Garber } & \text { Kieffer } \\ \text { Harvest } & \text { Lawrence } \\ \text { Koonce } & \text { Manning }\end{array}$

For Dwarfs
Seckel Sheldon

\section{Quinces}

Q UINCES make delicious preserves and marmalade; and very often quinces are added to other preserved fruits, just to give them the delightful quince flavor that every housewife knows. Quinces are easy to grow and bear regularly. Any well-drained soil is suitable.

$\mathrm{MEECH}-\mathrm{Pale}$ orange, of large size; fragrant, with fine flavor; productive and begins bearing early.

ORANGE-Attractive orange color; flesh cooks without toughness and is of fine flavor. Fruit keeps very late; highly prized; one of the most popular.
CHAMPION-Large, greenish yellow with tender flesh of delicate flavor; cooks as tender as apples; bears young and abundantly and keeps late.

\section{Figs}

THIS is one of the most highly-prized Southern fruits. But the trees are tender and unable to withstand severe cold. We know of several places in Baltimore, where Figs are grown and fruited, the branches being laid upon the ground before winter and well-covered with earth; then, lifted in the spring. For that matter, Figs have been fruited in Philadelphia and even in Rochester, N. Y., by laying and winter-covering them. But all that calls for timely care and taking pains. We recommend their planting only where Figs can stand outdoors without protection during winter.

We offer young trees of Celestial, Brunswick, Brown Turkey, Early Violet, White Genoa and White Marseilles. 


\section{Peaches}

BEAUTY, fragrance and delicacy of flavor make the peach the favorite orchard fruit. In commercial importance, it ranks next to the apple; in some sections, it ranks first. The trees are not so long-lived as apples and pears, but they come into bearing almost at once. As with apples, there is an almost endless list of varieties, constantly being added to. We grow and test these novelties, but we do not offer them until their value has become thoroughly established. Our list below contains only varieties of proved merit in this section.

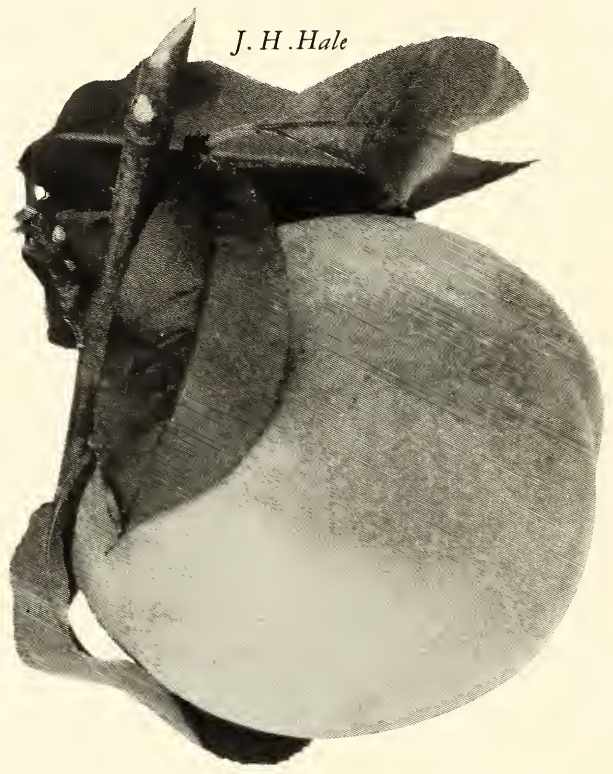

BELLE-Very large; skin white, with red cheek; flesh white, firm and of excellent flavor; fruit uniformly large and showy; tree a rapid grower and very prolific; ripens July i to is.

BEERS' SMOCK-Large, yellow, oblong; like Smock, but larger and a few days later; flesh firm and red at seed; freestone; one of the very best. October I.

CARMAN-Large, roundish, pale yellow with red cheek; flesh white, tender and melting; rich, sweet and of superior flavor; middle of July and the best of its season; a fine shipper and profitable market variety. Very hardy.

CHAMPION-Large creamy white with red cheek; flesh white, rich and juicy; freestone; good shipper. July.

CHAIRS'-Very large, yellow with red cheek; flesh yellow, firm and of good quality; tree a strong grower and good bearer. Early September.

CRAWFORD, EARLY-Large, golden yellow; flesh very juicy, rich, slightly sub-acid and of high quality; tree exceedingly vigorous and productive; a perfect freestone and a magnificent peach. First of August.

CRAWFORD, LATE-Very large, deep yellow with dark red cheek; flesh deep yellow, red at seed; melting, rich, of superb flavor; freestone; vigorous and productive. Very high quality. August I5.
ELBERTA-Large, yellow, with red cheek; freestone; juicy and well flavored; of uniform size and even ripening, the best known market peach. Early August.

FOX-Large, white with red cheek; flesh melting, sweet and good; fine for canning. First of September.

GREENSBORO-Beautifully colored crimson on yellowish white; juicy and good. June.

HALE (J. H. Hale) - Very large; fine, even yellow; perfectly round; excellent quality; variable, but fine where it does well. Last of July or early August.

HEATH CLING - Very large, pale yellowish white with faint blush; flesh greenish white, melting, exceedingly juicy with a rich, high and luscious flavor. Tree hardy and vigorous; fine for preserving; keeps late. The best clingstone. September I5.

HILEY-Very large; white with fine red cheek; of good quality; tree a moderate grower, but fruit buds are extremely hardy; a good shipper; freestone. July.

IRON MOUNTAIN-Large, white-fleshed freestone; hardy; last of August.

KRUMMEL-Large, nearly round; yellow with red cheek; flesh fine-grained and delicious; does equally well north and south. September ro to 25 .

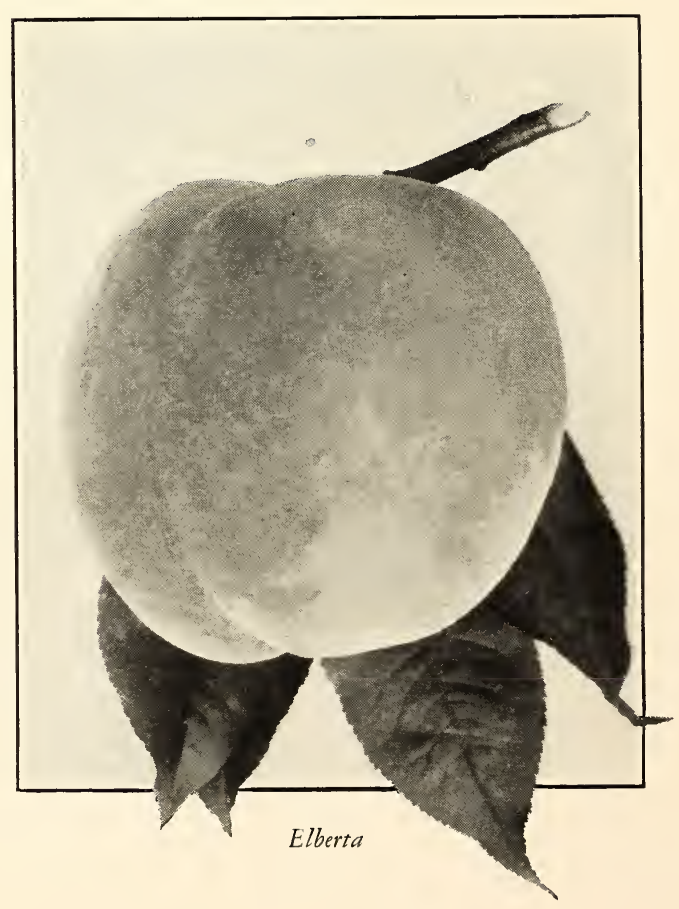


MAYFLOWER-Medium size, red all over; freestone with creamy white flesh. The earliest of the peaches. June.

MOUNTAIN ROSE-Large, roundish; white skin nearly covered with light and dark rich red; flesh white, slightly stained at pit; juicy, sweet and separates freely from the stone. Early July.

OLDMIXON FREE-Large and handsome; yellowish white with deep red cheek; flesh white, but red at the stone; tender, rich and excellent; productive and successful generally. Middle of August.

RAY-Large, creamy white, deeply tinged with crimson and yellow shadings; unusually handsome, of excellent quality, juicy, delicious and a good keeper; a strong grower; altogether a most satisfactory variety. August Io to 25 .

REEVES-Large, roundish, rich golden yellow with deep red cheek; a handsome peach of fine quality, especially recommended for home use. First of September.
SALWAY-Large, yellow, handsomely mortled with red; flesh deep yellow, juicy and melting; freestone; very productive. September.

STUMP — Large, creamy white with attractive red cheek; flesh white, juicy and of high flavor; productive. Middle of August.

WHEATLAND-Large, roundish, yellow with red cheek; very hardy; productive, of fine quality. August.

WONDERFUL-Large, uniform as to size and shape; fine golden yellow, partly covered with red; flesh yellow, rich, high flavored; freestone. October.

\section{The Best for Commercial Orchards}

$\begin{array}{lcc}\text { Elberta } & \text { Belle of Georgia } & \text { Hale } \\ \text { Carman } & \text { Hiley } & \text { Crawford Late } \\ \text { Champion } & \text { Chairs' Choice } & \end{array}$

\section{Nectarines}

NECTARINES require the same soil, situation and handling as Peaches. They are close kin to the peach, but have a smooth skin like the plum. The flavor is quite distinct, however.

ELRUGE-Medium, greenish yellow with dark red cheek; flesh pale green, melting, very juicy with a rich, high flavor and unsurpassed quality. August.

BOSTON-Large, yellow with red cheek; flesh yellow, sweet and delightful. Freestone. August.

\section{Persimmons}

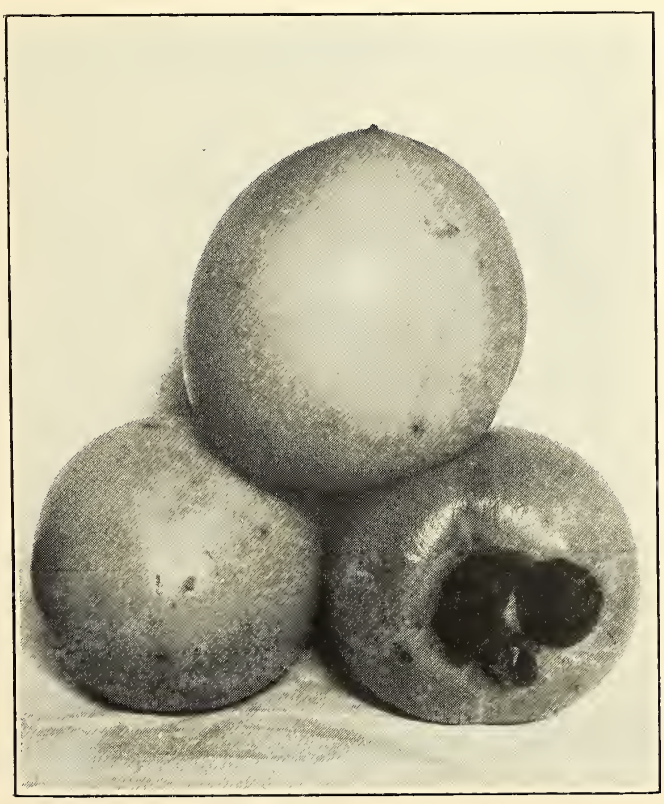

Tane NashiJapanese Persimmon
AMERICAN PERSIMMON-Our native Southern persimmon; fruit small, with flat seeds and very rich and luscious after frost.

JAPANESE PERSIMMON-This is one of the best fruits introduced in the South. The varieties are all many times the size of our native persimmon, more of the size and shape of tomatoes. The trees are small and bushy but wonderful bearers. The fruit should be gathered when fully matured (to protect it from the birds that are attracted to it when ripe), and then houseripened in a cool, dry, dark place. The skin is thick and the fruits can be kept until after Christmas. They have been kept till March. The trees are not entirely hardy north of the Potomac.

TANE-NASHI-Is large, conical and pointed; seedless; the commercial variety supplied the Eastern fruiterers by California.

TSURU-Long, slender, pointed; ripens late.

YEDDO-ICHI-Large; is edible as soon as fully ripe, and before softening; rub off the bloom, and if the dots are very dark and pronounced, the fruit is ripe and edible, though still hard. Is dark-fleshed. The yellow-fleshed varieties must be soft before eaten, and are nearly always seedless; the others have seeds.

YEMON-Very large, flat, tomato-shaped, almost foursided; seedless. 


\section{Plums}

PLUMS are not particular as to soils, but they do best in rather heavy soils. They bear 1 annually and the fruit is of such delicate texture and flavor and adapted to so many uses, as to make Plums especially desirable in every home orchard.

\section{Japanese Varieties}

A VERY valuable race of Plums, combining many desirable qualities of flavor, size and appearance. They succeed over a much wider range of territory than any other plums, make a strong growth, are hardy and bear regularly.

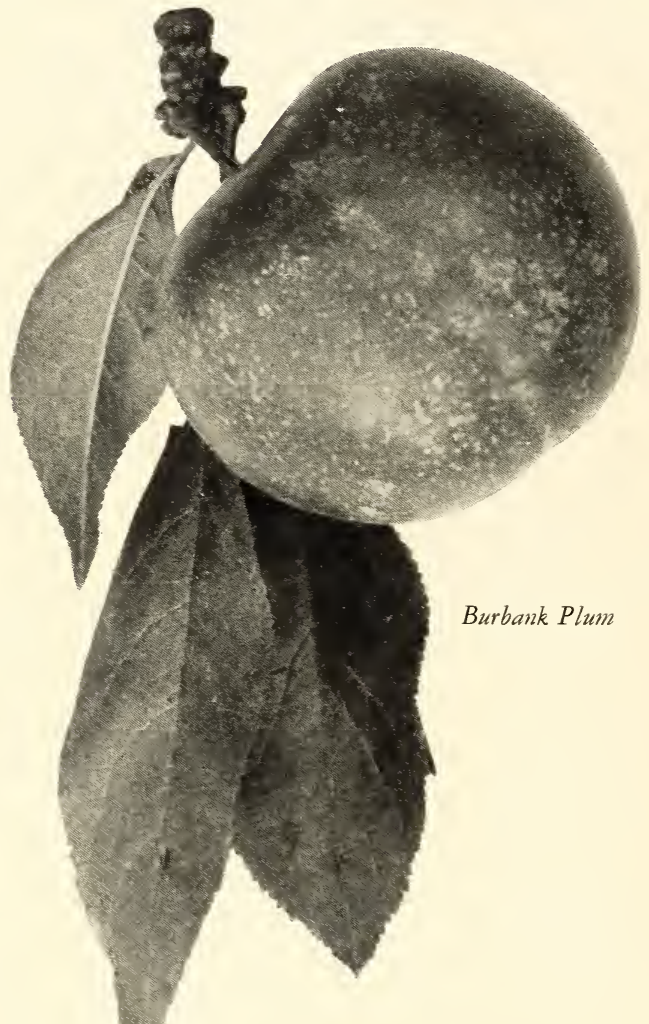

ABUNDANCE-Lemon-yellow ground, nearly covered with very light red; flesh yellow and very juicy; subacid with apricot flavor; bears early, regularly and heavily; hardy, of delightful taste. August I.

BURBANK-Large, cherry-red with deep yellow flesh, very sweet and pleasant; tree makes a strong, irregular growth and bears very young, often the second year. September I.

HALE-Large, clear yellow, nearly covered with red; flesh deep yellow, juicy and of rare quality; tree vigorous and a tremendous bearer; last of August.

OGON-Large, golden yellow; freestone; firm, sweet flesh; good for canning; tree vigorous. Last of July.

RED JUNE-Large, bright red; juicy and sweet; tree vigorous and hardy; very early, middle of July.

SATSUMA - Large, round, skin and flesh both dark purplish red; small seed; flesh firm, fine flavored; very hardy, strong grower. August.

WICKSON-Very large, red when fully ripe; flesh firm, juicy and sugary; keeps well and is one of the best in this group; ripens September 15 to 20.

\section{A Native Variẹty}

WILD GOOSE-A native American variety. Bright red, very handsome, juicy, sweet and rich in flavor. Recommended for home orchards. July.

\section{The Best European Plums}

BRADSHAW-Very large, dark violet-red, juicy and good; tree very vigorous and productive. July.

GERMAN PRUNE-Long, oval, purple; flesh green, sweet and pleasant; freestone; especially esteemed for drying and preserving. August.
GREEN GAGE-Small, yellowish green, with pale green flesh, very juicy and rich, unequalled in flaror; the very best for canning or cooking. August.

SHROPSHIRE-An improvement over the old Damson very large, dark purple; fine for preserving; vigorous and an enormous and regular bearer. September.
MULBERRIES-Make good shade trees with fine pyramidal heads and large leaves; but they should be planted away from the house; the berries, as they fall, attract flies; but the fruit is fine food for chickens and hogs; in their quarters is where Mulberries should be planted.
DOWNING, HICKS are the best large-fruited, everbearing varieties; WHITE ENGLISH has small, sweet fruit and makes a compact tree. 


\section{Cherries}

CHERRIES do well almost everywhere. They prefer a light, gravely or sandy soil, well drained and do not do well on wet or damp ground. They group themselves into two very distinct classes: The Sweet Cherries are larger, heart-shaped, and make larger, more spreading trees; the Sour Cherries are smaller, round, and make the smaller trees and of more compact growth.

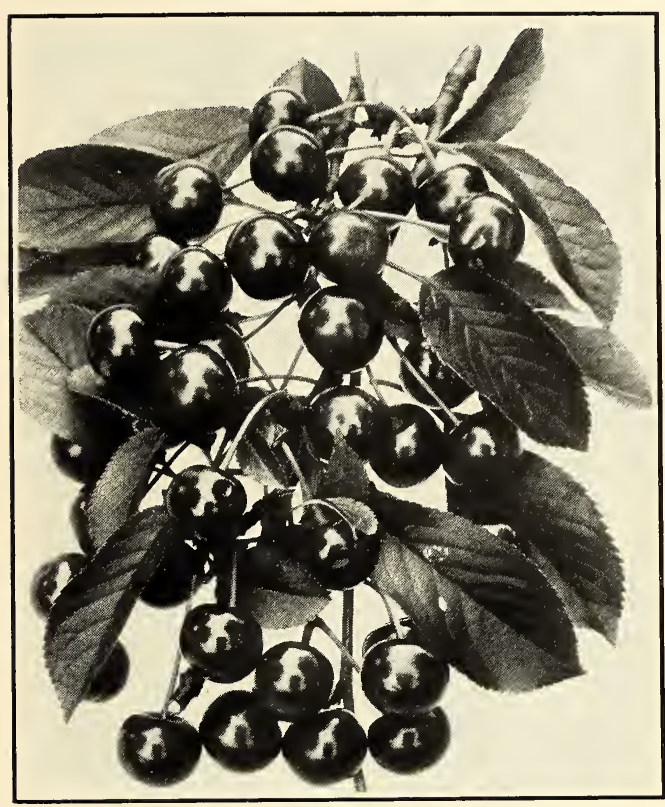

Richmond

\section{Sweet Cherries}

BLACK TARTARIAN-Of extra large size, often an inch in diameter; very dark, almost black when fully ripe, with dark flesh, firm, rich and fine in flavor; tree vigorous and very productive. A very popular early variety. June.

GOV. WOOD - Large, bright yellow, shaded with bright red; sweet, rich, delicious; strong tree, bearing heavily. June.

NAPOLEON-Of very largest size, pale yellow, amber in shade, dotted with deep red and with a bright red cheek; flesh very firm, of delicate flavor. This is the Cherry shipped East from the Pacific Coast as Royal Ann, early each spring. Ripens here in June.

SCHMIDT-Very large, deep black; flesh dark, tender, juicy and of fine flavor; very productive. July.

WINDSOR-Large, liver-colored fruit with firm flesh of fine quality; tree very hardy; a valuable late variety. July.

YELLOW SPANISH-Very large, often an inch in diameter; pale yellow with a handsome red cheek; fine, rich flavor; great size, beauty and productiveness make this a favorite variety. July.

\section{Sour Cherries}

DYEHOUSE-Medium size, bright red; sprightly, subacid; good quality.

LARGE MONTMORENCY-Fruit large and the finest flavored of any in this class; hardy and prolific.

MAY DUKE-Medium size; dark red; melting, rich and juicy; an old favorite.

MONTMORENCY - A beautiful, large, red, acid Cherry; very hardy and prolific. June Io.
MORELLO-Above medium size, dark red, turning almost black; flesh juicy, rich, subacid; makes a small tree. July.

RICHMOND-Medium size; red; flesh melting, juicy and at full maturity, of a rich, acid flavor; fine for cooking; commences ripening last of May and hangs long on the tree. Recommended for the home orchard.

\section{Apricots}

$\mathrm{T}$ HESE small, golden yellow fruits coming, as they do, a month or more before the earliest peaches, have a distinct and delightful flavor of rare delicacy. They are freestone and have small pits, are prized for dessert or for drying and canning. Apricots are hardy and bear annually. We suggest planting them with a west or north exposure.

ALEXANDER - Very large, oblong; yellow, flecked with red; sweet and delicate. July 12.

BUDD-Large; pale yellow with red cheek; sweet and juicy; the best late variety. August I.
EARLY GOLDEN-Small; pale orange with orange colored flesh; juicy and sweet. Last of June.

MOORPARK-Yellow; red cheek; firm flesh; rich, luscious flavor; one of the largest and finest. July. 


\section{Nut-Bearing Trees}

ALL over the country, there is a rapidly growing interest in nut culture. The demand for

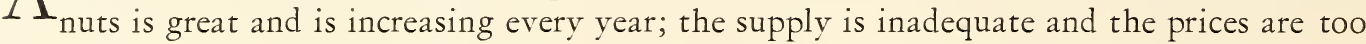
high. Palatable and nourishing as they are, nuts should be a common article of food here, as in Europe.

The nut-growing area of the United States has been gradually widened by acclimated varieties and trees, until today they grow Pecans in Iowa and English Walnuts in New York. Nut trees should be more generally planted; they are good for shade; their productiveness increases with age; they are long-lived; the wood of some, like Black Walnut, is worth more than mahogany. They do not yield returns at once, but the returns are sure and substantial.

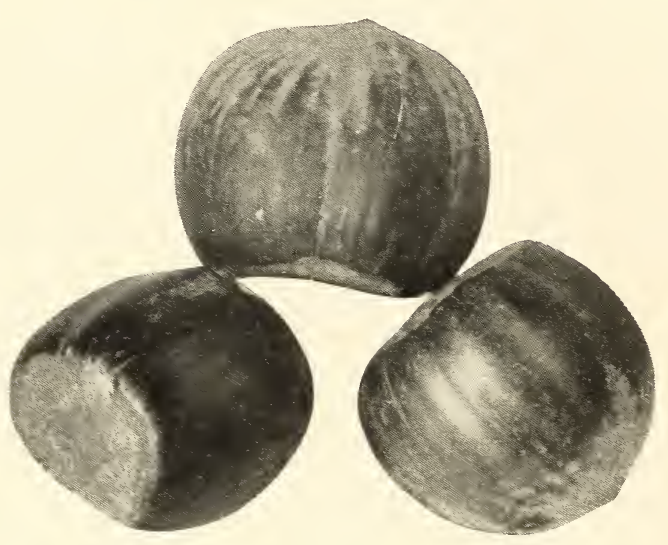

Filberts

BUTTERNUT. Juglans cinerea-A handsome, rapidgrowing tree with luxuriant tropical-looking leaves; nuts smaller than those of Black Walnuts.

CHESTNUT, AMERICAN SWEET. Castanea americana. -Makes a stately tree with fine leaves, good for shade and bears small nuts of sweetness and flavor far beyond the quality of the larger European Chestnuts.

WALNUT, AMERICAN BLACK. Juglans regia-Thick, hard shells; meat of delicious flavor, in demand by candy-makers.

WALNUT, ENGLISH. J. regia-Fine shade trees with paper-shell nuts.

WALNUT, JAPAN-Makes a large, spreading tree with large leaves; nuts are borne in large clusters, have shells thicker than English Walnuts, not so thick as Black Walnuts; of excellent quality.

WALNUT, CORDIFORMIS-A Japanese variety; makes a large, spreading tree; nuts small, fairly thin-shelled.

WALNUT, SIEBOLDIANA-Japanese. Extremely hardy; makes a good shade tree; nuts fairly thin-shelled, in clusters, of good quality. Bears young.
PECANS, PAPER-SHELL-No nuts have so fine a flavor. Within the last few years, Pecans have come into their own; they command now the highest prices paid for any nuts, home-grown or imported. We grow VAN DEMAN, SCHLEY and STUART, all "Jumbo" nuts with thin shells; also Paper-shell Seedlings.

FILBERTS or HAZELNUTS-Make large bushes, 6 to 8 feet high, with beautiful foliage and very ornamental; the nuts, like very small chestnuts, have a far finer, richer flavor. Make fine, useful hedges that are very ornamental.

ALMONDS-Grow like peach trees. Everybody knows what Almonds are like. We have the Hard-Shell and Soft-Shell or Ladies' Almond.

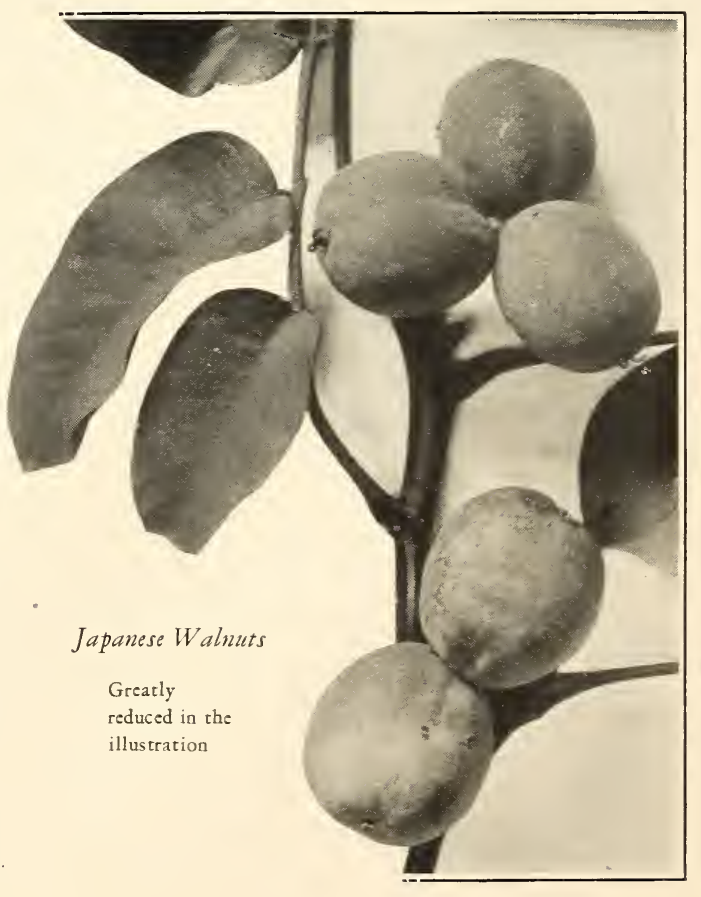




\section{Grapes}

$\mathrm{T}^{\mathrm{T}}$ is so easy to grow Grapes, that no home should be without at least a few vines. They 1 grow readily along fences, are ideal for covering arbors and take up so little room that city homes without space for fruit trees, can always find a place for a Grape vine or two. Suitable varieties, of course, need to be selected, and those in our list are kinds that we can recommend. Grapes are so refreshing and delightful to the taste, so welcome an addition to the breakfast or dinner table, so useful in making jellies, preserves and wholesome beverages, that no home grounds, however small, should be without a few vines.

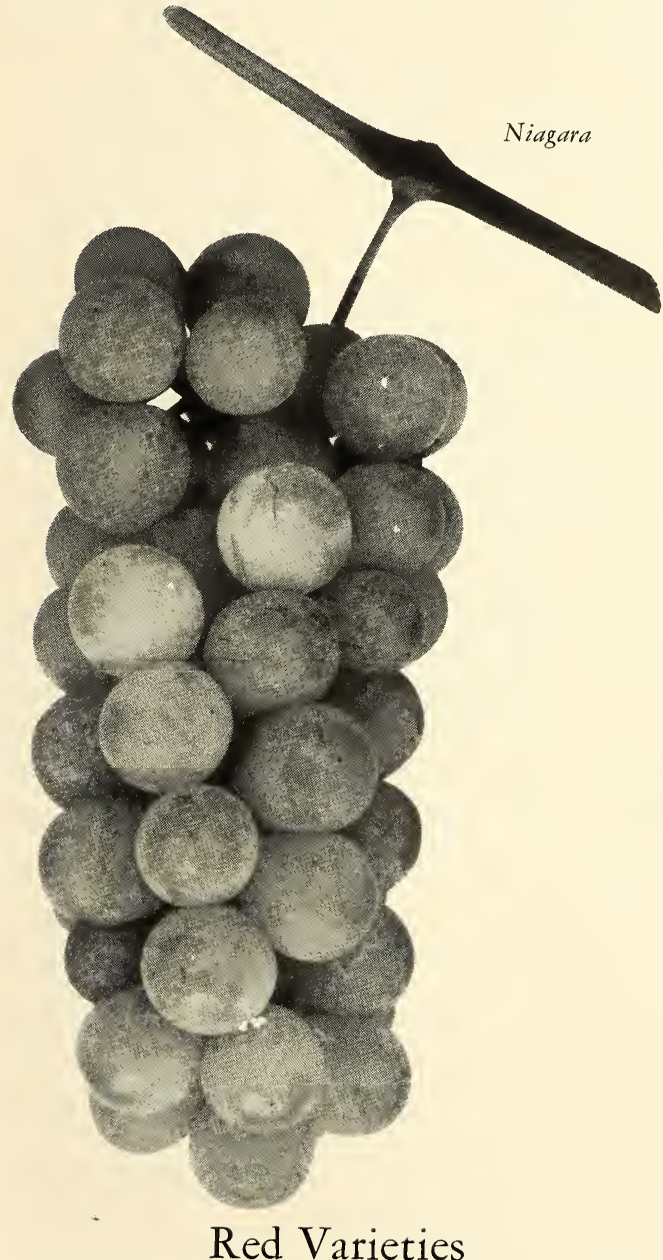

BRIGHTON-Bunch large and beautifully formed; berries medium to large; red when first ripe, changing to reddish purple if allowed to hang long on vine; very sweet and tender; vine vigorous and productive.

CATAWBA-Bunch and berry large; dark red when ripe; very juicy and rich. One of our best Grapes, succeeding well in the valley and Piedmont regions of Virginia. DELAWARE-Bunches of medium size, but very compact; berries rather small, beautiful light red in color; of delicate and delicious flavor; exceptionally sweet.

\section{Black Varieties}

CONCORD-Bunches large and compact; berries large, round, black, juicy and fine; grows vigorously and bears wonderfully. No Grape is better known, more generally popular, nor planted so largely in so wide a territory; succeeds wherever grapes are grown and nowhere to greater perfection than right here.

MOORE'S EARLY-Bunch medium; berry quite large; black. The vine is very hardy, healthy, vigorous and a great bearer.

\section{White Varieties}

NIAGARA-Bunches large and long, with large berries of greenish white, yellowish white when full ripe; tender and sweet but must be dead ripe for best quality; remarkably vigorous, hardy and productive. The leading white grape everywhere.

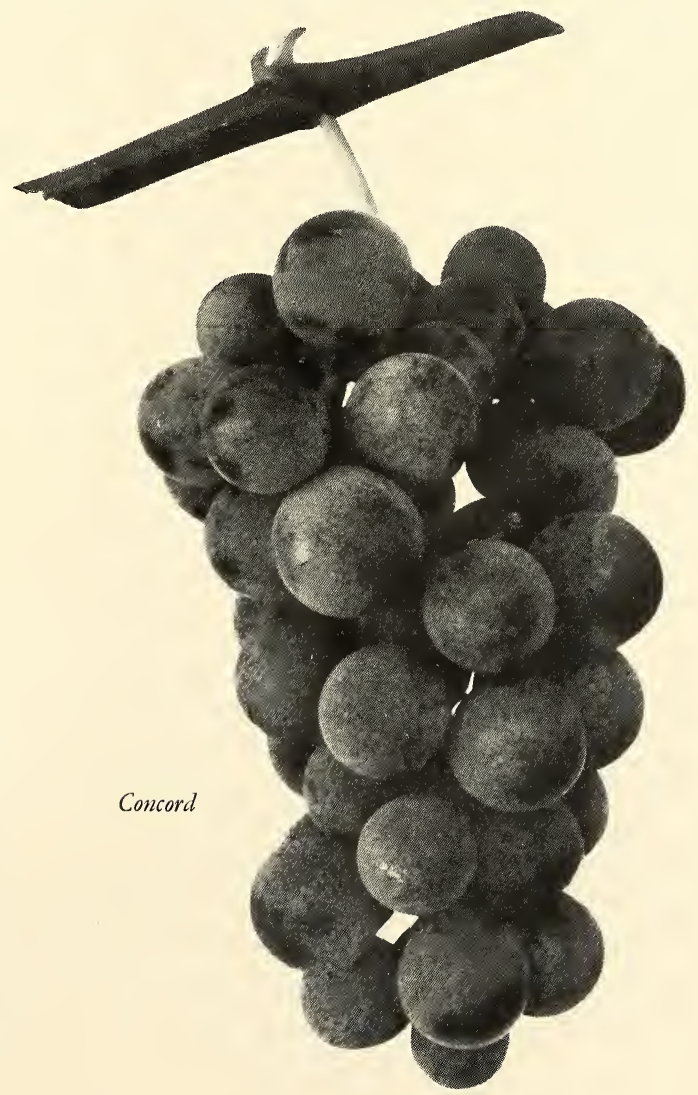




\section{Blackberries}

RLACKBERRIES should be set 5 by 2 feet apart; if the soil is rich, a foot farther each way. Good fruit always sells well and Blackberries make such fine jam and yield such refreshing juices that wherever space permits, a few bushes, anyway, should be planted.

BLOWERS - Superb in every way; of immense size, hardy, productive and fine quality. One of the very best.

ELDORADO-Hardy, vigorous and productive; berries large, of good quality and borne in clusters; sweet and melting, hardly any core; keeps well.

EARLY HARVEST-Medium size, good quality, firm and attractive; valuable for extreme earliness.

RATHBUN-Large, sweet and of high flavor; makes a neat compact bush and is absolutely hardy; firm, with small seeds and no hard core.

SNYDER - Of medium size and good quality; extremely hardy and able to withstand the hardest winters.

WILSON-Very large, productive, early; ripens evenly for one harvesting; popular for market and a favorite home variety.

\section{Wineberry}

Something like the raspberry in bush and fruit; hardy, grows vigorously and bears an abundance of berries of a pretty amber color changing to crimson when ripe; of distinct, sprightly, subacid taste; excellent for canning, jellies and pies. Is immune to rust, very ornamental and ripens over a long season beginning in July.

\section{Logan Berry}

Very large berries, crimson, of mild, pleasant taste. Loganberry juice is a favorite beverage; the fruit makes good jam and delicious pies.

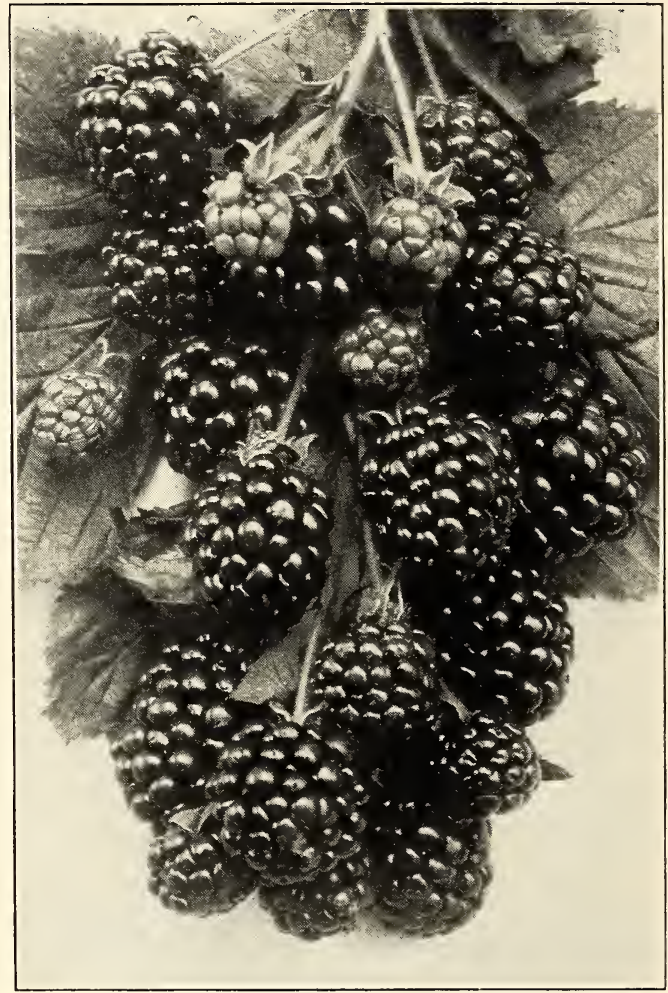

Blowers Blackberries

\section{Currants}

URRANTS come in with the raspberries but last long after raspberries are gone; in fact, none of the small fruits will hang on the bushes without injury, as long as Currants will. They do best in good soil, well cultivated; but they can be tucked away in the corner or among the trees and will give a good account of themselves.

CHERRY-Very large, red berries; bush makes a strong growth and bears moderately; fine for preserving.

FAY-Large in size and rich red in color; of good flavor and very prolific; one of the best.
RED CROSS-Long clusters with berries of good size and excellent quality.

WHITE GRAPE-Bunches moderately long and berries large and less acid than the red currants; very produstive; the best white variely.

\section{Gooseberries}

THE market demand for the fruit has increased the demand for Gooseberry bushes for planting; and they are good things to plant, whether the fruit is grown for sale or for use at home.

DOWNING-Large, whitish green berries. The bushes are strong-growing, upright and very productive. One of the best.

INDUSTRY-Immense, dark red berries of excellent quality; an enormous bearer.
HOUGHTON-Rather small berries, but an enormous bearer; pale red with tender flesh and sweet, pleasant taste.

PEARL-Large, greenish white berries; bush, a strong grower that bears heavily. 


\section{Raspberries}

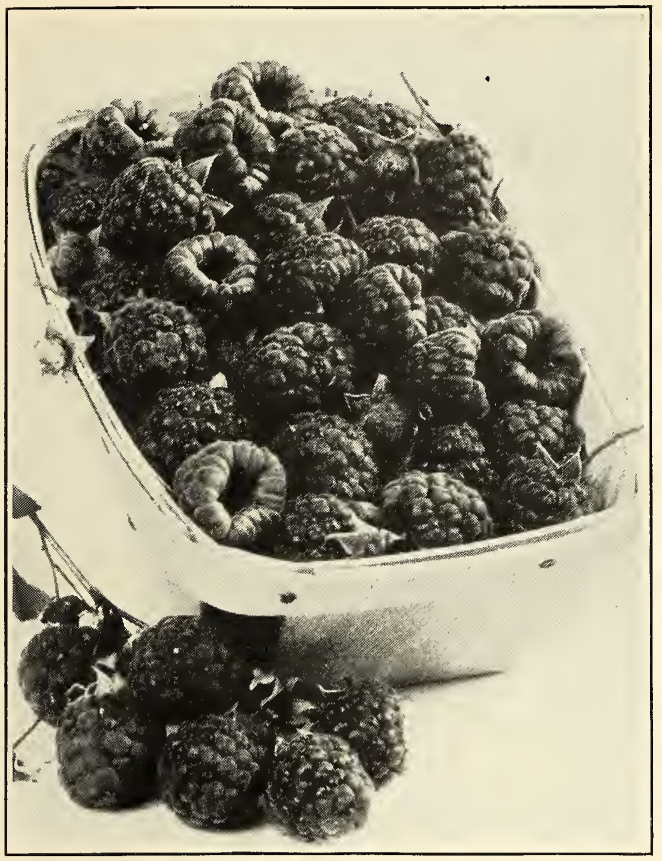

St. Regis Fruitbearing

CUMBERLAND-Black. Berries very large, firm and of good quality; unsurpassed for hardiness and yield; midseason.
COLUMBIAN-Dark purple. Berries of largest size, moderately firm and of good quality; bushes are vigorous and wonderfully productive. Columbian is the best of all raspberries for canning, preserving or drying.

CUTHBERT-Red. Berries are large to very large; moderately firm, with high, sprightly flavor; strong grower, with abundant, healthy foliage. Cuthbert succeeds almost everywhere and is especially recommended for the cotton states.

GREGG-Black. One of the largest of the black raspberries; firm, moderately juicy and sweet; grows and bears well; ripens late and matures all its fruit at once, making harvesting easy.

KANSAS-Black. Large berries of fine quality; early, hardy, vigorous, productive.

MILLER-Red. Very large berries with small core, bright red color that does not fade; early, heavy bearer; very popular.

MUNGER-Black. Resembles Gregg but ripens a week later; large, juicy; a favorite canning and cooking variety.

ST. REGIS-Red. Ripens with the earliest and while the principal crop is in the spring, St. Regis has the peculiar habit of maturing its fruit on new canes all through the summer and until October. Bright red color, good size, excellent quality and continuous fruiting habit make St. Regis an ideal berry for the home garden.

\section{Asparagus}

$\mathrm{E}$ ARLY Asparagus is a great delicacy; it must come fresh from the garden; the embalmed Asparagus that comes in tins, is not for the discriminating palate. Asparagus roots cost little; an Asparagus bed is permanent; its yield is great and lasting. Every vegetable gadren should have its own Asparagus bed.

Directions for Plantinc. Give land a heavy top dressing of manure, plow deep, harrow, roll and run rows 4 or 5 feet apart, about 12 inches deep, then put in 2 or 3 inches of thoroughly rotted manure mixed with bone or bone and potash; then a little good top soil on that and ground is ready for plants, which should be 12 inches apart, being careful to spread roots out well with top up. Cover with 2 or 3 inches of soil. When plants come up, work the earth to them gradually from both sides and from time to time as plants grow, until the ground is level. The middles between the rows should also be worked shallow and grass and weeds kept out. In the fall, after one or two frosts, cut the tops off and burn them, then cover patch with stable manure. Early in the spring, work this manure in the ground, adding, if necessary, some commercial fertilizer on both sides of rows. Salt spread broadcast early in spring, 5 to to bushels to an acre, is a benefit.
BARR-Very large, early and prolific.

COLUMBIAN-Throws large, white shoots that do not color up.

CONOVER - A staple, standard variety; often ready to cut the second year after planting.

DONALD-Delicate greenish-white stalks, tender and of good size.

GIANT-Good size, early, prolific, long-lived; a profitable market variety in the South.

PALMETTO-The earliest; slender stalks, tender, delicious.

WASHINGTON-A new variety, recently disseminated by the Department of Agriculture. Large, tender, productive and rust-resistant. 


\section{Strawberries}

THE Strawberry bed for home use should be planted in rows I 8 inches apart and the plants $I_{\text {I } 2}$ inches apart in the rows. with walking space left between every three rows, to permit gathering the fruit without treading on the plants.

In the Spring, the plants should be mulched with clean straw to keep the fruit clean, and the runners should be pinched off, to encourage fruiting instead of making new plants.

Most Strawberry varieties are bi-sexual, but not all. We list here only varieties that have perfect, or self-fertilizing flowers.

New Strawberries - and "new" fruits of other kinds-are constantly being introduced with great promises; where they appear to have merit over older kinds, we get them for trial. It is better for amateurs to plant the varieties that have been thoroughly tested and their value demonstrated. What pays and pleases your neighbor, is apt to do well for you.

The commercial fruit-grower does not need this admonition nor more than the condensed descriptive matter below. In one of the greatest Strawberry-growing sections of the country, these varieties are too well-known as producers and money-makers, to require much to be said about them.

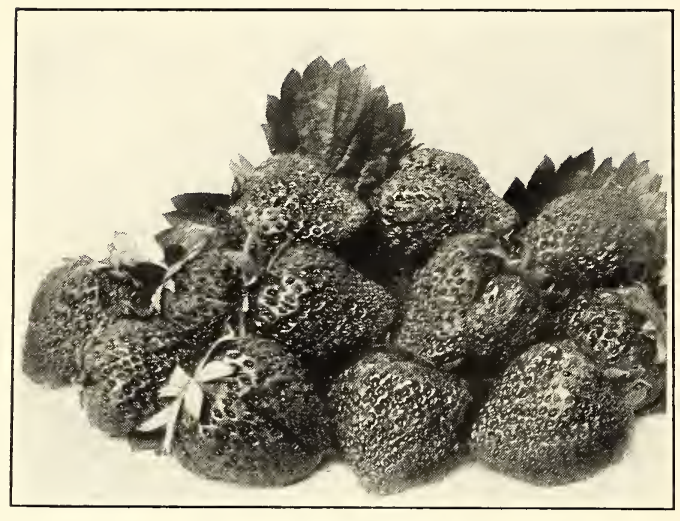

Strawberries

PROGRESSIVE-Everbearing. Medium to large and dark red in color; every bloom matures a berry; the plants bloom and mature another crop of berries during August, September and October.

\section{Horse-Radish}

No garden should be without its Horse-radish. As a relish for meats it is unsurpassed. The land should be rich, well manured, plowed deeply, harrowed and free from lumps. As it is a great vegetable to spread, plant in a roomy space by itself. Make rows 15 inches apart, set plants 12 inches from each other. Plant shoots about five inches long, making holes for same with a stick, and set them about two inches under the soil. Have the shoots cut squarely across the bottom, but cut slanting at the top, in order that one side may be a little longer than the other. Keep free from weeds for the first and second seasons, after which the Horse-radish will take care of itself.
CHESAPEAKE - The standard of excellence hereabouts. Blooms very late and so escapes late frosts; healthy, with fine leaves and deep roots, making it droughtresistant; matures even its last fruit to equal size with the first.

GANDY - The best late variety. Bright red, firm, of uniform size and good quality.

GLEN MARY-Large to very large berries, highly colored, uniform in size, firm and a good shipper; a staple, standard variety.

MARYLAND-Large, dark red and of the finest quality. Is immune to rust.

OHMER - Very large to immense berries, beautiful color and great productiveness; fruit of uniform size from first to last; of proved quality and value; rust-resistant.

PREMIER - Extra early; uniform bright red color, bears well, ships well and stands at the head of the extraearly varieties.

TENNESSEE-Productive, large, with good color and is free from rust. A good, dependable, tested variety.

\section{Rhubarb, or Pie Plant}

This very desirable vegetable comes early in the spring. The large stems of the leaves are used for pie-making and stewing; it is also valuable for medicinal purposes. We grow the best varieties.

A deep, rich soil is indispensable to secure large, heavy stalks. Plant in rows 4 feet apart, with the plants 3 feet distant. Set so that the crowns are about an inch below the surface. Top-dress annually in the fall with stable manure and fork under in the spring. 


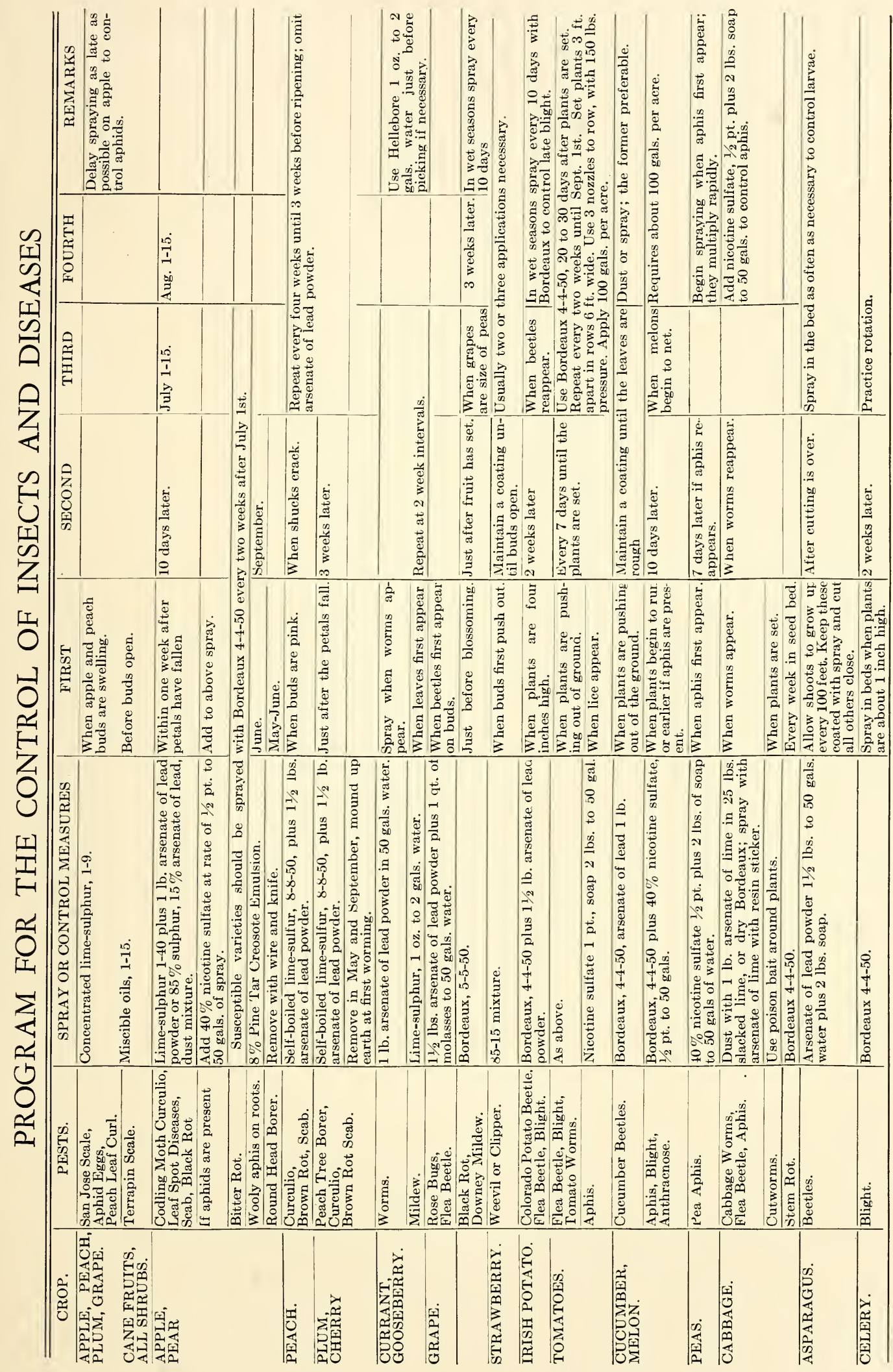




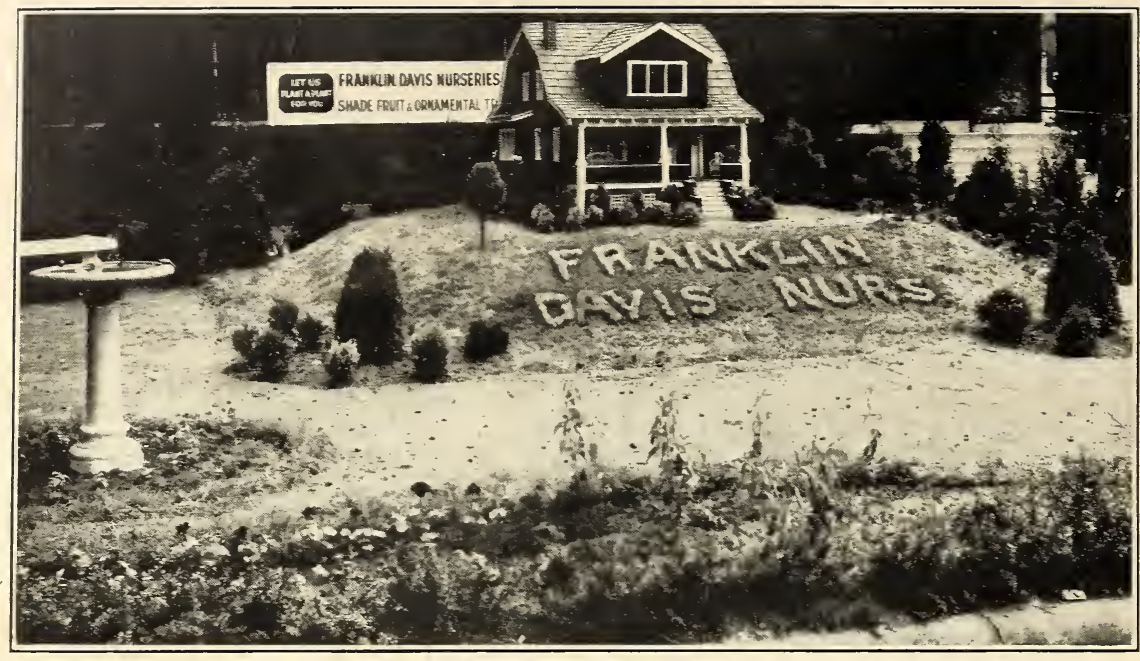

House and garden in miniature, planned and planted by our Landscape Department; this and a very fine collection of ornamental plants can be seen opposite our office at 629 North Howard Street, Baltimore, where visitors are always welcome.

FRANKLIN DAVIS NURSERIES, INC.

Office: 629 North Howard Street, Baltimore

Nurseries: Mullikin, Md. 